\title{
Opioid and neuroHIV Comorbidity - Current and Future Perspectives
}

\author{
Sylvia Fitting ${ }^{1} \cdot$ MaryPeace $_{\text {McRae }^{2}} \cdot$ Kurt F. Hauser $^{3,4,5}$ (D) \\ Received: 26 February 2020 / Accepted: 2 July 2020 / Published online: 2 September 2020 \\ (C) The Author(s) 2020
}

\begin{abstract}
With the current national opioid crisis, it is critical to examine the mechanisms underlying pathophysiologic interactions between human immunodeficiency virus (HIV) and opioids in the central nervous system (CNS). Recent advances in experimental models, methodology, and our understanding of disease processes at the molecular and cellular levels reveal opioid-HIV interactions with increasing clarity. However, despite the substantial new insight, the unique impact of opioids on the severity, progression, and prognosis of neuroHIV and HIV-associated neurocognitive disorders (HAND) are not fully understood. In this review, we explore, in detail, what is currently known about mechanisms underlying opioid interactions with HIV, with emphasis on individual HIV-1-expressed gene products at the molecular, cellular and systems levels. Furthermore, we review preclinical and clinical studies with a focus on key considerations when addressing questions of whether opioid-HIV interactive pathogenesis results in unique structural or functional deficits not seen with either disease alone. These considerations include, understanding the combined consequences of HIV-1 genetic variants, host variants, and $\mu$-opioid receptor (MOR) and HIV chemokine co-receptor interactions on the comorbidity. Lastly, we present topics that need to be considered in the future to better understand the unique contributions of opioids to the pathophysiology of neuroHIV.
\end{abstract}

Keywords Antiretroviral therapy · Astrocyte $\cdot$ Blood-brain barrier $\cdot$ Buprenorphine $\cdot$ C-C motif chemokine receptor 5 (CCR5) · COVID-19 · Cytochrome P450 3A4 (CYP 3A4) · Endogenous opioid system of peptides and receptors · Functional selectivity/ biased agonism $\cdot \mathrm{HIV}$-associated neurocognitive disorders $\cdot$ Maladaptive neuroplasticity $\cdot$ Methadone $\cdot$ Microglia $\cdot \mu$-Opioid receptor $(O P R M 1) \cdot$ neuroHIV O Oligodendroglia $\cdot$ P-glycoprotein · Pro-brain-derived neurotrophic factor (pro-BDNF) . Synaptodendritic degeneration

\section{Overview}

\section{The Opioid Crisis}

Kurt F. Hauser

kurt.hauser@vcuhealth.org

1 Department of Psychology and Neuroscience, University of North Carolina at Chapel Hill, Chapel Hill, NC 27599-3270, USA

2 Department of Pharmacotherapy and Outcomes Science, School of Pharmacy, Virginia Commonwealth University, Richmond, VA 23298, USA

3 Department of Pharmacology and Toxicology, School of Medicine, Virginia Commonwealth University, 1217 East Marshall Street, Richmond, VA 23298-0613, USA

4 Department of Anatomy and Neurobiology, School of Medicine, Virginia Commonwealth University, Richmond, VA 23298-0709, USA

5 Institute for Drug and Alcohol Studies, Virginia Commonwealth University, 203 East Cary Street, Richmond, VA 23298-0059, USA
Opioid abuse in the United States (U.S.) has reached catastrophic levels. According to the latest World Drug Report, 53.4 million people worldwide used opioids in 2017, which is $56 \%$ higher than in the previous year (UNODC 2019a). North America remains the region with the highest non-medical use of opioids with a staggering 4\% of the population aged 15-64 using opioids (UNODC 2019a, c). In 2017, the burden of opioid use in the U.S. had accounted for 42 million healthy years of life lost due to premature death and disability (Institute for Health Metrics and Evaluation 2017; UNODC 2019a). During 2017, there were 70,237 overdose related deaths, out of which 47,600 (67.8\%) were caused by opioids, which was a 12\% increase from 2016 (Scholl et al. 2018; UNODC 2019c). The Centers of Disease Control and Prevention (CDC) reports that on average 130 Americans die from an opioid overdose each day (CDC 2017). Due to 
the constant rise in deaths involving opioids, the U.S. Government declared the opioid crisis/epidemic a public health emergency in 2017 (U.S. Department of Health and Human Services 2017). Injection drug use increases the likelihood of contracting human immunodeficiency virus (HIV) and drug abuse and HIV have long been described as interrelated epidemics (Swan 1997; Leshner 1998; Nath et al. 1999, 2002). Despite this understanding, opioid use disorder (OUD) and HIV remain a huge public health concern (Strathdee and Beyrer 2015; Peters et al. 2016). In fact, the opioid crisis is seen as a major roadblock in several aspects of public health, including thwarting the goal of eliminating HIV within the next decade (Fauci et al. 2019; Lerner and Fauci 2019).

OUD is also likely to exacerbate many negative aspects of the COVID-19 pandemic (Alexander et al. 2020; Becker and Fiellin 2020; NIDA 2020; Wakeman et al. 2020). Not only are individuals with OUD more vulnerable to SARS-CoV-2 and liable to spread the infection, social-distancing practices create isolation, despair, and economic hardships, heightening opioid abuse (with inherent respiratory depression depending on the amount of tolerance developed) and the probability of overdose (Becker and Fiellin 2020; Wakeman et al. 2020). By virtue of its greater safety profile and decreased likelihood for abuse (Bell and Strang 2020), the use of buprenorphine via telemedicine has become advantageous for managing OUD during the COVID-19 pandemic (Leppla and Gross 2020; Samuels et al. 2020) but presents new challenges (Khatri and Perrone 2020).

The current opioid crisis did not happen quickly; in fact, it has been described as occurring in three phases. The first phase began in the late 1990s with an increase in the number of prescription opioids. This led to overdose deaths that were attributable to natural and semisynthetic opioids, such as methadone (Kolodyny et al. 2015; CDC 2017). The second phase began in 2010 in which heroin took the lead as the principal cause of overdose deaths. The most recent, third wave, began in 2013 in which highly potent synthetic opioids, such as fentanyl and its analogs became the main cause of mortality (Kolodyny et al. 2015; CDC 2017). The entry of fentanyl and its analogs into the clandestine market has changed the dynamics of the opioid market in the U.S. The synthetic opioids, such as fentanyl, are several orders of magnitude more potent than morphine, easily smuggled, and frequently and inconsistently mixed with lower quality drugs increasing the probability of overdosing. According to the National Forensic Laboratory Information System of the U.S. Drug Enforcement Administration (DEA), fentanyl accounted for one-third of the illicit opioids seized in 2017 (UNODC 2019c) and has become a global problem (UNODC 2019b).

\section{The Pathophysiology of Opioid Abuse}

The effects of opioid abuse on the central nervous system (CNS) have been extensively examined. Immediate effects of opioids result in decreased levels of consciousness, sedation (Collett 1998; Thompson 2000; Indelicato and Portenoy 2002), drowsiness, and sleep disturbances (Moore and Dimsdale 2002; Bourne and Mills 2004; Qureshi and LeeChiong 2004). While acute opioid exposure can impair cognition in healthy subjects (Lawlor 2002; Ersek et al. 2004), enduring cognitive and psychomotor deficits occur with chronic opioid use (Sjogren et al. 2000; Dublin et al. 2015; Roberts et al. 2018; Wollman et al. 2019; Serafini et al. 2020), including altered pain perception (opioid-induced hyperalgesia), dysregulated reward/saliency processing, hyperkatifeia, and epigenetic changes, which can persist years following abstinence (Ersche et al. 2006; Browne et al. 2020). The behavioral changes seen with long-term opioid use are accompanied by lasting structural and epigenetic (e.g., altered DNA methylation and expression of noncoding RNAs) alterations in brain regions implicated in mood, reward, and motivation (Upadhyay et al. 2010; Dublin et al. 2015; Volkow and Morales 2015; Koob and Volkow 2016; Serafini et al. 2020).

Up to $90 \%$ of post-mortem tissues sampled from opiate abusers display brain edema (Buttner 2011), astrogliosis and microgliosis especially in the hippocampus (Oehmichen et al. 1996), white matter, and subcortical regions at autopsy (Tomlinson et al. 1999; Anthony et al. 2005; Buttner et al. 2006; Buttner and Weis 2006). The reactive gliosis is accompanied by increases in proinflammatory cytokines and inflammatory mediators, including TNF- $\alpha$, IL- $1 \beta$, and nitric oxide synthase (NOS) (Dyuizen and Lamash 2009). Opiates especially drive the enhanced activation of heme-oxygenase, NOS, and cyclic GMP-dependent-protein kinase (Liang and Clark 2004) and production of reactive nitrogen species (RNS) such as peroxynitrite (Salvemini 2009), and resultant nitrosative damage (Zou et al. 2011). Nitrosative damage is an important endpoint for opiate exposure (Pasternak et al. 1995; Liang and Clark 2004; Salvemini 2009) and key site of convergence for the oxidative stress accompanying HIV protein exposure (Hauser and Knapp 2014; McLane et al. 2018).

For delayed heroin overdose death after a survival period of $5 \mathrm{~h}$ or more, studies report neurovascular disorders, hypoxic ischemic leukoencephalopathy, and region-specific atrophy with neuronal losses that can include the hippocampal formation, the cerebellar Purkinje cell layer and olivary nucleus (Protass 1971; Ginsberg et al. 1976; Gosztonyi et al. 1993), as well as other areas (Buttner 2011; Cadet et al. 2014). Loss of neurons and synaptic connections is supported by postmortem reports of smaller mean relative volumes in various brain regions in individuals with OUD, including cortical areas (Danos et al. 1998; Pezawas et al. 1998), the basal ganglia 
(Muller et al. 2015, 2019), prefrontal cortex (Cadet et al. 2014), and hypothalamus (Muller et al. 2018). Interestingly, leukoencephalopathy, atrophy (Cadet et al. 2014), and increased hyperphosphorylated tau-containing neurofibrillary tangles are reported with chronic opiate abuse compared to age-matched controls (Ramage et al. 2005; Anthony et al. 2010; Kovacs et al. 2015). Glycogen synthase kinase $3 \alpha$ or $\beta$ (GSK- $3 \alpha / \beta$; the pan antibody used in this study does not discern $\alpha$ from $\beta$ isoforms) and/or cyclin-dependent kinase-5 $(\mathrm{Cdk}-5)$ are increased in the frontal and temporal cortices, the locus coeruleus, and the hippocampus, respectively, and correlate with microgliosis (Anthony et al. 2010). Further, more prolonged use increases the risk of accelerated age-related and even Alzheimer's-like pathological changes (Ramage et al. 2005; Anthony et al. 2010; Kovacs et al. 2015) and cognitive impairment (Gruber et al. 2007).

Moreover, heroin use is associated with symmetric T2 and fluid-attenuated inversion recovery (FLAIR) hyperintense white matter lesions of the CNS using magnetic resonance imaging (MRI), which coincide with increased microgliosis and inflammation at the same sites (Upadhyay et al. 2010; Bora et al. 2012; Qiu et al. 2013; Alaee et al. 2014; Li et al. 2016; Shrot et al. 2017). Although a few studies have started to examine opiate-HIV interactions in white matter (see below), we predict that the interactive effects on myelin dysregulation will significantly worsen CNS outcomes.

Preclinical studies indicate opioid-induced neuroimmune signaling alter the saliency of opioid reward and physical dependence (Narita et al. 2006; Hutchinson et al. 2008, 2009). Direct injections of astrocyte-conditioned medium containing cytokines into the nucleus accumbens (NAc) increase morphine conditioned place preference (Narita et al. 2006). Drugs reported to selectively attenuate glial inflammation block morphine conditioned place preference and attenuate symptoms of opioid withdrawal (Narita et al. 2006; Hutchinson et al. 2009; Liu et al. 2010). $\mu$ (MOR), $\delta$ (DOR), and $\mathrm{k}$ (KOR) opioid receptors are expressed by subsets of astrocytes and microglia (Stiene-Martin and Hauser 1991; Eriksson et al. 1992; Stiene-Martin et al. 1993; Ruzicka et al. 1995; Gurwell et al. 1993; Hauser et al. 1996; Turchan-Cholewo et al. 2008; Maduna et al. 2018) and are involved in opioid tolerance and dependence to varying degrees (Kieffer and Gaveriaux-Ruff 2002; Berger and Whistler 2010; Morgan and Christie 2011). Despite some reports of morphine triggering immune activation via Toll-like receptor 4 (TLR4) (Terashvili et al. 2008; Hutchinson et al. 2010; Coller and Hutchinson 2012; Hutchinson et al. 2012; Theberge et al. 2013; Lacagnina et al. 2017) by binding to a myeloid differentiation protein-2 intermediary (Wang et al. 2012), this is contrary to the typical actions of opiates, which by themselves (and in the absence of a priming event such as HIV co-exposure) tend to suppress immune function (Eisenstein 2019). A vast majority of the immune, antinociceptive, and other physiological effects of opioids are mediated by opioid receptors per se and not TLR4 (Hu et al. 2011; Fukagawa et al. 2013; Stevens et al. 2013; Mattioli et al. 2014; Eisenstein 2019).

Overall, the findings indicate that immune signaling plays a critical role in the pathophysiology of OUD and associated physical dependence. How opioids effect neuroHIV, as well as how opioid abuse and dependence are altered by neuroHIV or whether opioid-HIV interactions result in a unique disease state are discussed.

\section{HIV Neuropathology in the Context of Opioid Use Disorder - Clinical and Preclinical Evidence}

\section{Preclinical and Clinical Findings-a Complicated Picture}

People infected with HIV (PWH) with OUD have an increased incidence of neuroHIV and CNS complications (Bell et al. 1998; Nath et al. 1999, 2000a, 2002; Anthony et al. 2008; Meyer et al. 2013; Smith et al. 2014). Injection drug use increases the probability of contracting HIV (Nath et al. 1999) and opioid drugs intrinsically alter the pathogenesis of HIV. PWH who develop intractable pain syndromes related to peripheral neuropathies often receive opioid drugs for treatment (Mirsattari et al. 1999; Denis et al. 2019). PWH who misuse opioids are more likely to undertake risky sexual behavior and are less likely to adhere to combined antiretroviral (ARV) therapy (cART) regimens (Lemons et al. 2019). Opioid receptors are widely expressed on immune cells and opioids can modulate immune function (Donahoe and Falek 1988; Plotnikoff 1988; Rouveix 1992; Adler et al. 1993; Carr and Serou 1995; Carr et al. 1996; Sheng et al. 1997; Banerjee et al. 2011; Purohit et al. 2012), which typically (but not always) result in immune suppression (Wybran et al. 1979; McDonough et al. 1980, 1981; Donahoe and Falek 1988; Donahoe et al. 1991; Falek et al. 1991; Novick et al. 1991; Chao et al. 1996a; Peterson et al. 1998; Rogers and Peterson 2003; Stein et al. 2003; Roy et al. 2006; Rittner et al. 2008). The "opiate cofactor hypothesis" proposes opioids contribute directly to the pathogenesis of acquired immune deficiency syndrome (AIDS) (Donahoe and Vlahov 1998), in part, because MOR activation can increase HIV replication in immune cells (Peterson et al. 1990, 1992, 1993, 1999; Ho et al. 2003). Furthermore, MOR and HIV co-receptors, including both CCR5 (El-Hage et al. 2013; Yuan et al. 2013; Arnatt et al. 2016) and CXCR4 (Pitcher et al. 2014) can interact via convergent downstream signaling and perhaps via direct molecular interactions (Rogers et al. 2000; Rogers and Peterson 2003; Steele et al. 2003; Chen et al. 2004; Song 
et al. 2011; Arnatt et al. 2016). MOR-CCR5 or CXCR4 interactions are highly contextual and can promote (Guo et al. 2002; Steele et al. 2003) or inhibit (Strazza et al. 2014) HIV expression, depending on the nature and duration of exposure (see Fig. 9; Berman et al. 2006) and cell type involved (Kim et al. 2018). Depending on the outcome measure, Tat expression reduces morphine's efficacy and potency (Fitting et al. 2012, 2016; Hahn et al. 2016). Antagonizing CCR5 with maraviroc reinstates morphine potency in an antinociceptive assay and restores physical dependence in Tat exposed, morphine-tolerant mice (Gonek et al. 2018).

Epidemiological studies suggest OUD can increase AIDS progression (Donahoe and Vlahov 1998; Dronda et al. 2004; Meijerink et al. 2014, 2015). In the pre-cART era, opiate abuse was found to exacerbate HIV encephalitis (HIVE) (Bell et al. 1998, 2002). In Indonesian injection heroin abusers who lacked access to cART, CD4 counts (a measure of HIV progression) were reduced compared to $\mathrm{PWH}$ not using heroin (Meijerink et al. 2014). However, with the introduction of cART, the clinical picture has significantly changed with a $50 \%$ decline in the rate of death from AIDS, reduced incidence of opportunistic infections and HIVE, and a 40-50\% decrease in the incidence of HIV-associated dementia (HAD), the most severe form of HIV-associated neurocognitive disorders (HAND) (Maschke et al. 2000; McArthur et al. 2010; Saylor et al. 2016). Nevertheless, chronic opiate exposure (which almost always is confounded by the use of other illicit and legal drugs) in PWH can worsen neuroHIV (Anthony et al. 2005; Bell et al. 2006; Anthony et al. 2008) and cognitive impairment (Rodriguez Salgado et al. 2006; MartinThormeyer and Paul 2009; Byrd et al. 2011; Smith et al. 2014; Martin et al. 2018; Rubin et al. 2018) despite cART, even though some studies fail to show that opioids worsen neuroHIV (Royal et al. 1991; Applebaum et al. 2010) or HAND (Martin et al. 2019). Opiate exposure in cARTtreated PWH worsens CD4 counts and viral loads (Ryan et al. 2004), neuropathology (including increased tauopathy; Smith et al. 2014), CNS inflammation (Anthony et al. 2005, 2008; Smith et al. 2014), and neurocognition (Applebaum et al. 2009; Byrd et al. 2011; Meyer et al. 2013) including deficits in memory and working memory (Byrd et al. 2011). Table 1 gives an overview on reported interactive effects of HIV and opioids in some of the clinical and preclinical CNS studies referenced in this review.

Although translational, "bench-to-bedside", research is important, reverse-translational approaches and multiple preclinical models are essential to better understand complex disease and improve established therapies (Singer 2019). Evidence suggests that HIV compartmentalizes within the CNS early during the course of the infection establishing a separate reservoir harboring "intact proviral" HIV (Churchill et al. 2016; Bruner et al. 2019) within resident neural cell populations
(Bednar et al. 2015; Sturdevant et al. 2015; Veenhuis et al. 2019) and perivascular macrophages (Fischer-Smith et al. 2001; Burdo et al. 2013; Rappaport and Volsky 2015). Preclinical studies assessing opioid interactions with HIV or viral proteins permit mechanistic understanding of how particular CNS cell types, including neurons, astroglia, and microglia are affected and contribute to accentuating effects of opiates on neuroHIV, which are discussed in detail below.

\section{Cellular and Molecular Interactions in Astroglia, Microglia, and Neurons}

Prior reviews have outlined how opiate drugs likely exacerbate neuroHIV pathology in neurons and glia (Hauser et al. 2005; Dutta and Roy 2012; Hauser et al. 2012; Reddy et al. 2012; Hauser and Knapp 2014; Liu et al. 2016a; Murphy et al. 2019) including in the enteric nervous system (Galligan 2015; Meng et al. 2015). Opioid-HIV pathophysiological interactions are complex and differ depending on the timing and duration of co-exposure, the pharmacology of the opioid drug involved, the cell types and brain regions targeted, host and viral genetics, and are highly contextual (Hauser and Knapp 2014, 2018). A summary of the cellular and molecular interactions in various CNS cell types is also reviewed in detail in Table 2.

\section{Opioid and HIV Interactive Pathology in Astroglia}

Although the extent to which astroglia display productive infection is debated (Russell et al. 2017; Ko et al. 2019), there is nevertheless considerable evidence of proviral integration in the CNS of PWH (Gorry et al. 2003; Churchill et al. 2009), infectious animal models (Eugenin et al. 2011), and/or cultured human fetal astrocytes (Tornatore et al. 1994; Liu et al. 2004; Do et al. 2014; Narasipura et al. 2014; Li et al. 2015; Nath 2015; Li et al. 2020). Integrated HIV sequences have been identified in astrocytes in HIV-infected CNS tissue by laser capture microdissection (Churchill et al. 2006). Astroglia appear to infect via nonclassical, CD4-independent mechanisms, that can have the appearance of virologic synapses, adding to the debate (Liu et al. 2004; Do et al. 2014; Li et al. 2015; Nath 2015; AlHarthi et al. 2019; Li et al. 2020).

Irrespective of whether they become infected, MOR-expressing, HIV or HIV protein-exposed astrocytes release greater amounts of inflammatory cytokines and dysfunction sufficient to harm bystander neurons upon treatment with opiates (El-Hage et al. 2005, 2008b; Zou et al. 2011; El-Hage et al. 2014). MOR-expressing subsets of glia, especially microglia and astroglia, are prominent in driving the interactive opioid and HIV neuropathogenesis (Hauser et al. 2007, 2012; Hauser and Knapp 2014; Liu et al. 2016a; Chilunda et al. 2019; Murphy et al. 2019). When MOR is deleted from glia 


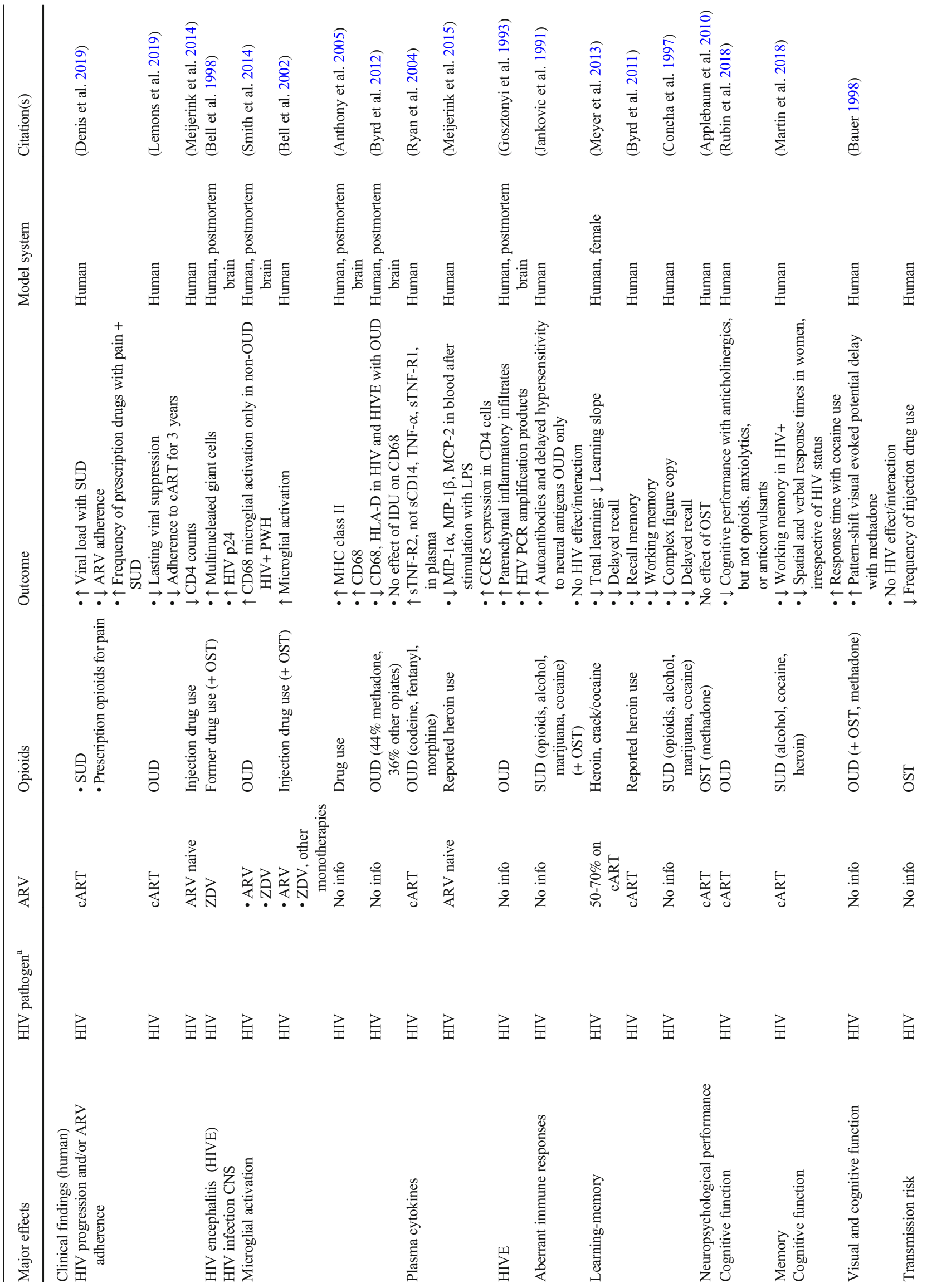




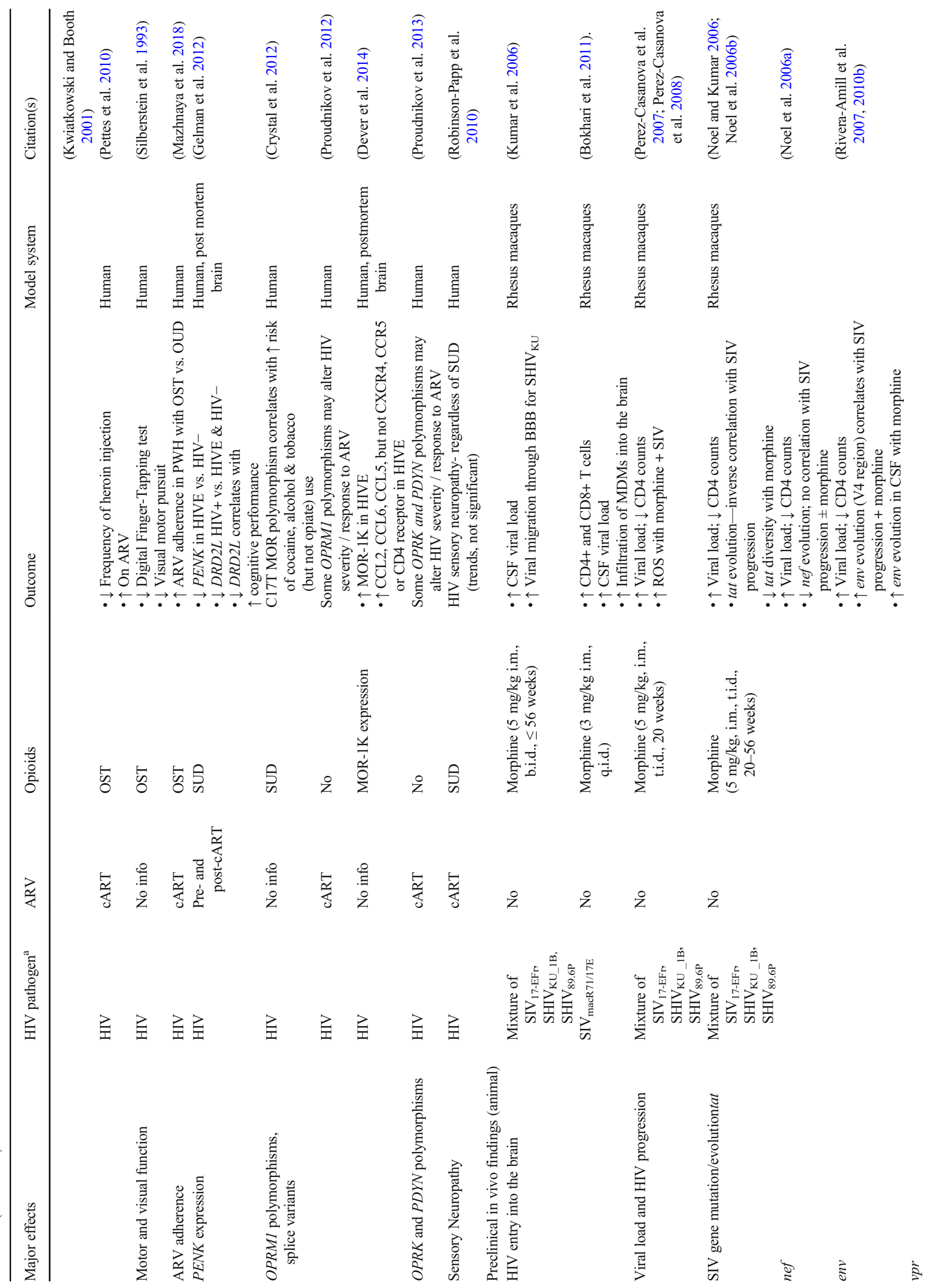




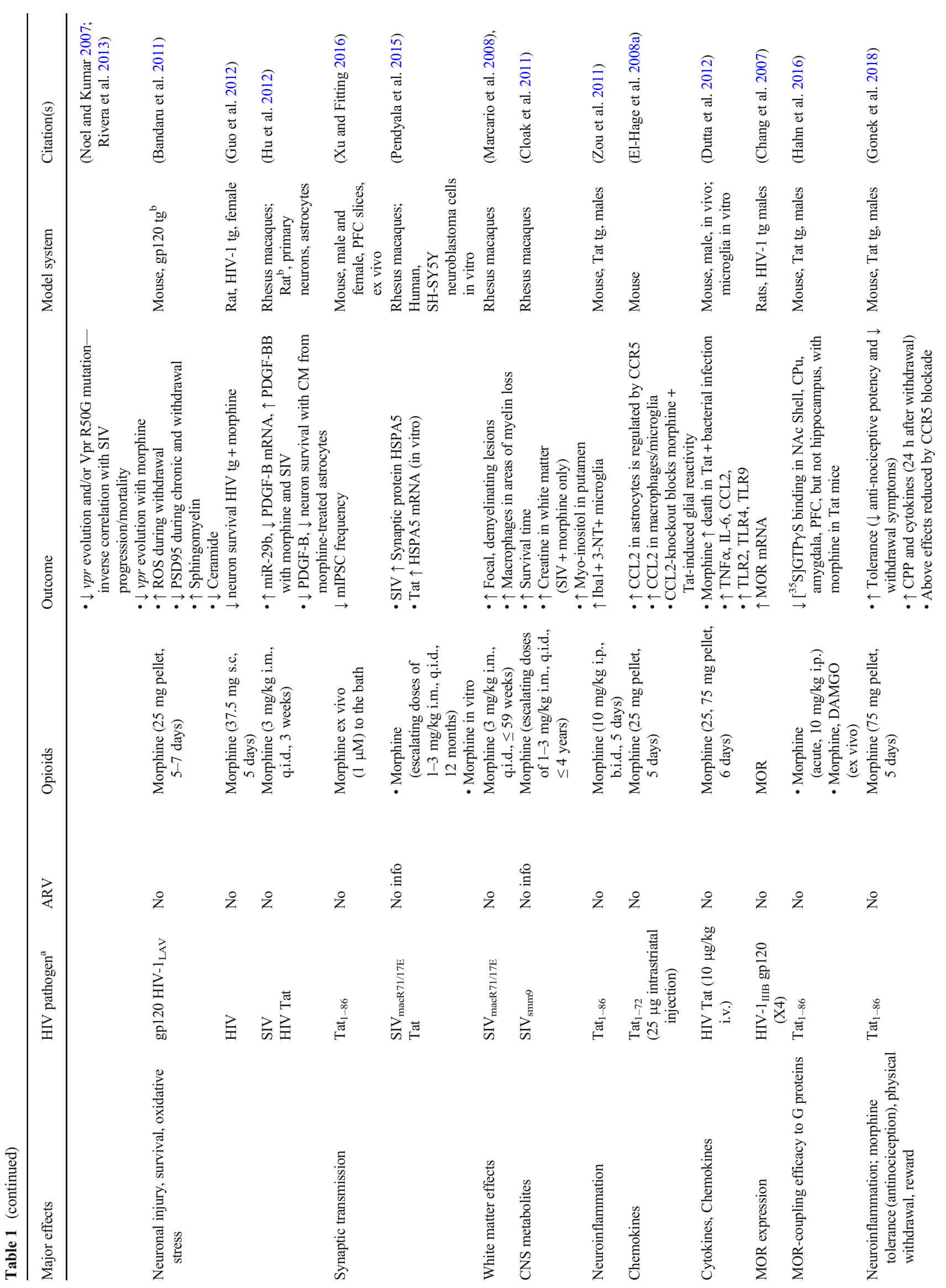




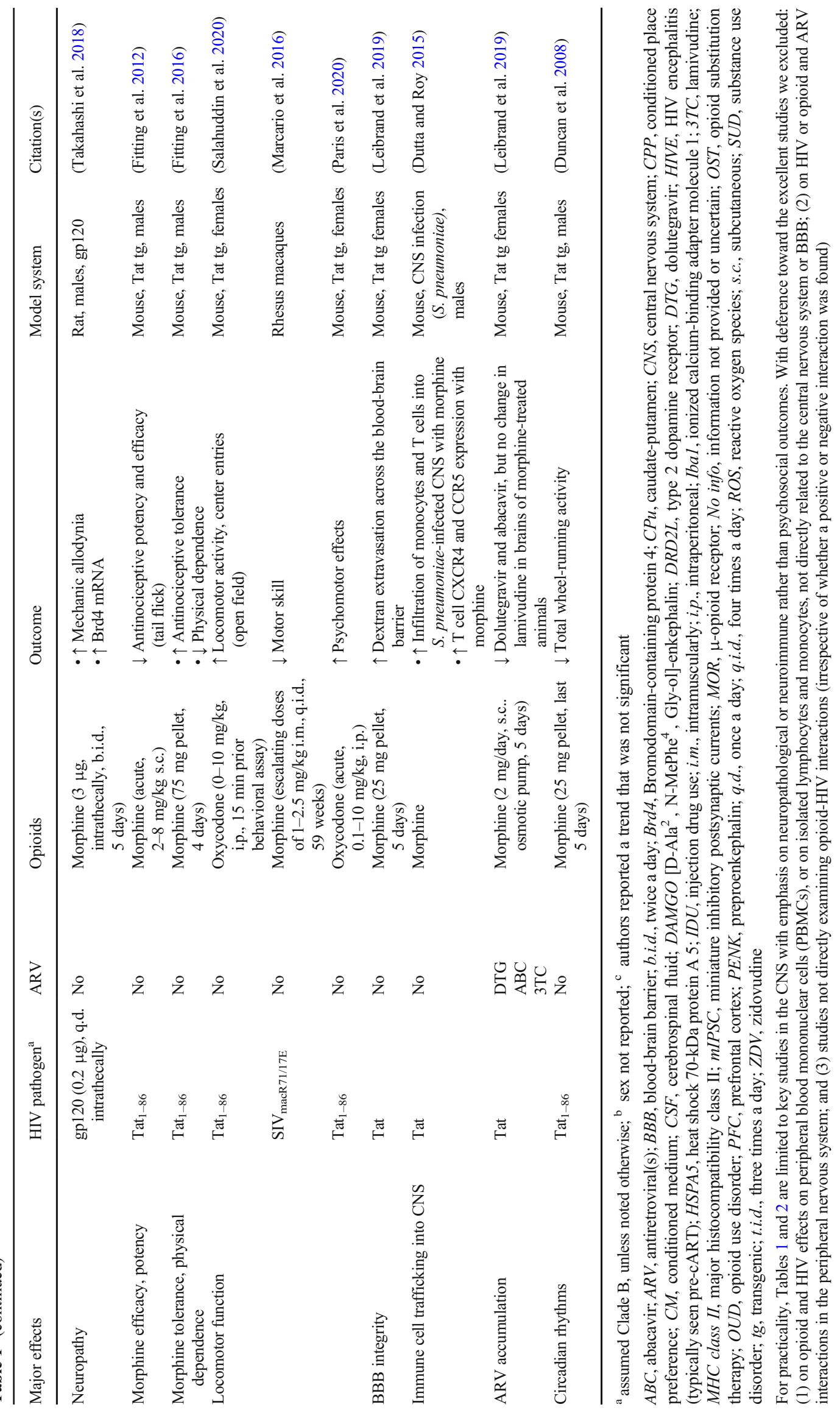


(astrocytes and microglia), morphine no longer increases the death of Tat-exposed striatal medium spiny neurons (MSNs) (Zou et al. 2011). Conversely, if MOR is deleted from MSNs, morphine exacerbates the neurotoxic effects of Tat in MSNs (Zou et al. 2011). The proinflammatory effects of Tat alone or in combination with morphine on glia are mediated through a Beclin-1-dependent autophagy pathway (Rodriguez et al. 2017; Lapierre et al. 2018). Drugs with selective glial antiinflammatory activity (i.e., ibudilast or AV411) attenuated the deleterious effects of HIV and opiate exposure, including HIV-1 replication, cytokine release, and neurotoxicity in vitro (El-Hage et al. 2014). Thus, the observed neuronal death is largely mediated by MOR-expressing glia (Zou et al. 2011), including astroglia (El-Hage et al. 2005, 2008b) and microglia (Turchan-Cholewo et al. 2008; Bokhari et al. 2009; TurchanCholewo et al. 2009; Gupta et al. 2010).

The direct contributions of astrocytes to opioid and HIV interactions have been discussed previously (Dutta and Roy 2012; Hauser et al. 2012; Reddy et al. 2012; Hauser and Knapp 2014). Subsets of astroglia can express MOR, DOR and KOR (Stiene-Martin and Hauser 1991; Eriksson et al. 1992; Ruzicka et al. 1995; Gurwell et al. 1996; Hauser et al. 1996; Peterson et al. 1998; Stiene-Martin et al. 1998, 2001), as well as endogenous opioid peptides (Vilijn et al. 1988; Shinoda et al. 1989; Spruce et al. 1990; Hauser et al. 1990; Low et al. 1992). It appears that the 'early' events triggering the release of proinflammatory cytokines (i.e., TNF- $\alpha$ and IL-1 $\beta$ ) from astroglia can be mediated by HIV Tat exposure alone (El-Hage et al. 2005, 2006a, b, 2008a). Opioids enhance HIV-1-induced inflammation later during the inflammatory cascade by exacerbating the sustained release of CCL5 from astrocytes, which subsequently triggers the release of CCL2 thereby enhancing the recruitment and activation of macrophages/microglia (El-Hage et al. 2008a) (Fig. 1). This is caused by the morphine-dependent exacerbation of Tat-induced increases in intracellular calcium concentration $\left(\left[\mathrm{Ca}^{2+}\right]_{\mathrm{i}}\right)$ in astroglia (El-Hage et al. 2005), which accelerates the trafficking of NF- $\mathrm{BB}$ p65 (RelA) subunits to the nucleus and sustained CCL2, CCL5, and IL-6 transcription in astrocytes (El-Hage et al. 2008b).

\section{Opioid and HIV Interactive Pathology in Microglia}

Unlike in astrocytes, opiate and HIV interactions in microglia tend to be self-limiting (Turchan-Cholewo et al. 2009). Opiates initially trigger large increases in the production of proinflammatory cytokines (Hauser, unpublished), reactive oxygen (ROS) and nitrogen (RNS) species (TurchanCholewo et al. 2009), and the release of glutamate (Gupta et al. 2010) and ATP (Sorrell and Hauser 2014) extracellularly in Tat-exposed microglia. The release of glutamate is mediated by the catalytic subunit of the cystine-glutamate antiporter $\mathrm{x}_{\mathrm{c}}{ }^{-}$(xCT) (Gupta et al. 2010). Interestingly, following acute increases in the release of cytokines (e.g., TNF- $\alpha$; unpublished), morphine no longer increases Tatinduced cytokine levels at $24 \mathrm{~h}$; instead, their levels are reduced by opiate-dependent proteasome inhibition. The proteasome inhibitor, MG115, mimics the effects of morphine in decreasing proteasome activity at $24 \mathrm{~h}$ and blocks TNF $\alpha$, IL-6, and CCL2 release from microglia, but does not increase ROS or RNS production (Turchan-Cholewo et al. 2009). The ubiquitin proteasome system (UPS) is typically viewed as contributing to opiate tolerance and physical dependence by modulating MOR downregulation (Massaly et al. 2014; Caputi et al. 2019), rather than MOR activity constraining the UPS. Thus, while HIV-exposed, MOR-expressing microglia show a burst of ROS and proinflammatory cytokine production in response to morphine, the cytokine release collapses within $24 \mathrm{~h}$ seemingly because sustained opiate exposure inhibits the UPS thereby preventing degradation of the I $\kappa \mathrm{B}$ subunit and nuclear translocation of NF- $\mathrm{BB}$ (Turchan-Cholewo et al. 2009).

While neither astroglia nor microglia alone mimic the full inflammatory profile seen with opiates and HIV in the CNS; in combination, the neuroimmune signature more accurately mimics that seen in neuroHIV. Accordingly, we have proposed that opioids promote positive feedback through separate actions in astroglia and microglia in neuroHIVresulting in spiraling inflammation and cytotoxicity (Hauser et al. 2005, 2007).

\section{Opioid and HIV Interactive Pathology in Neurons}

Besides accentuating HIV-induced neurotoxicity via glialmediated mechanisms, morphine appears to converge with HIV Tat to dysregulate ion homeostasis and dendritic injury through potential direct actions on neurons, even though some contributions of glia cannot be excluded in this study (Fitting et al. 2014a). Combined morphine and Tat exposure accelerates the formation of Tat-induced focal dendritic varicosities/swelling via a MOR-related mechanism that was caused by focal increases in $\mathrm{Na}^{+}$influx and $\left[\mathrm{Ca}^{2+}\right]_{i}$, an overload of $\mathrm{Na}^{+} / \mathrm{K}^{+}$-ATPase, ATP depletion, and a collapse in mitochondrial inner membrane potential (Fitting et al. 2014a). Importantly, morphine's additive effects were mediated via a MOR-related mechanism, as the exacerbating effects of morphine were absent in neurons from MOR knockout mice, thus excluding TLR4 involvement (Fitting et al. 2014a). Further, morphine exacerbated Tat-dependent focal losses in ion homeostasis by mobilizing $\left[\mathrm{Ca}^{2+}\right]_{\mathrm{i}}$ through ryanodine-2 (RyR2)-sensitive sites (Fitting et al. 2014a) (Fig. 2). Although morphine typically acts via MOR in an inhibitory manner by activating $\mathrm{G}_{\mathrm{i} / \mathrm{o}}$-proteins (Sharma et al. 1977; Moises et al. 1994; Al-Hasani and Bruchas 2011), MOR-dependent stimulation of PI3-kinase and $\mathrm{Ca}^{2+}$ mobilization (Leopoldt et al. 1998) in neurons via the $G \beta \gamma$ protein 


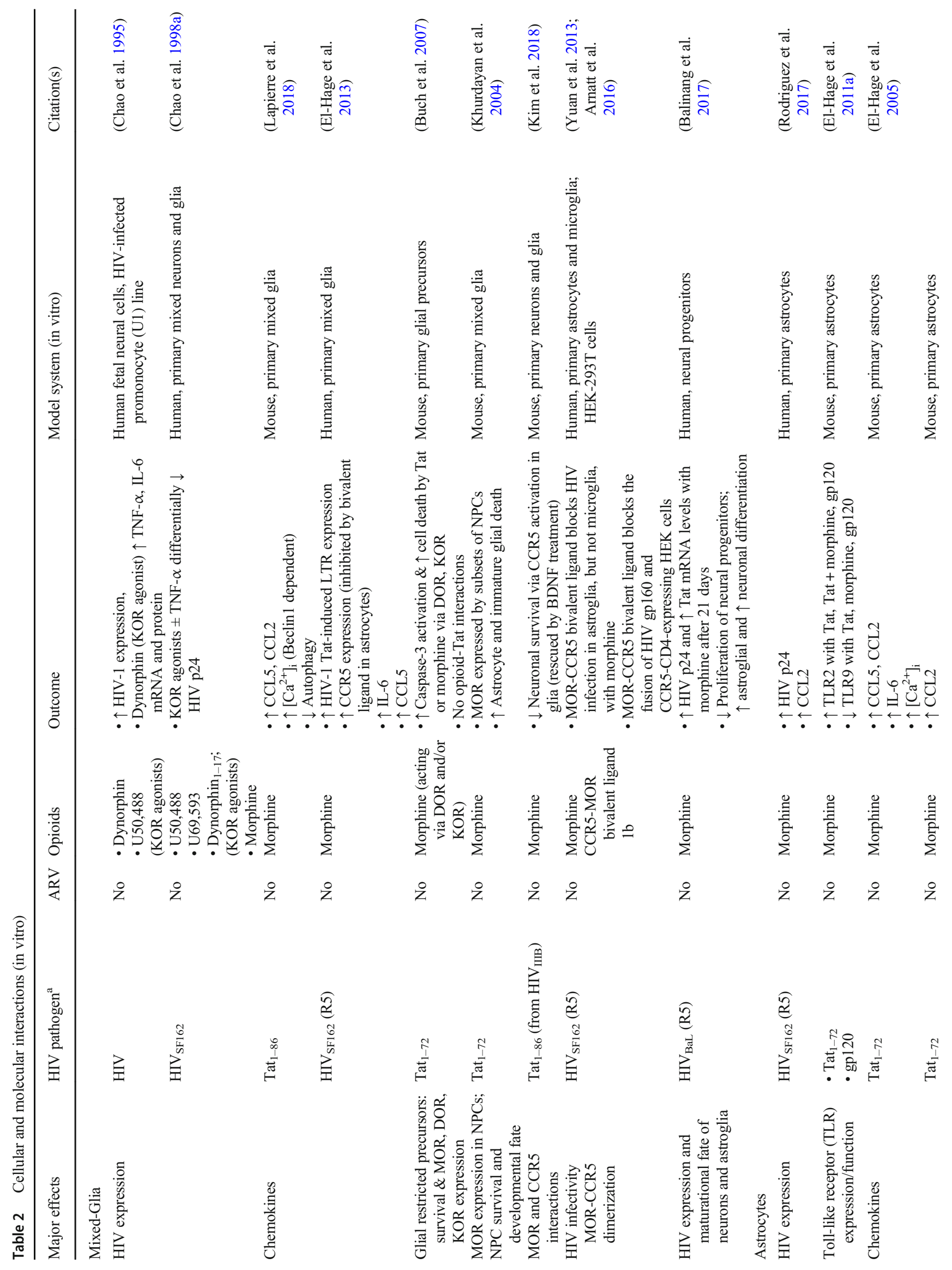




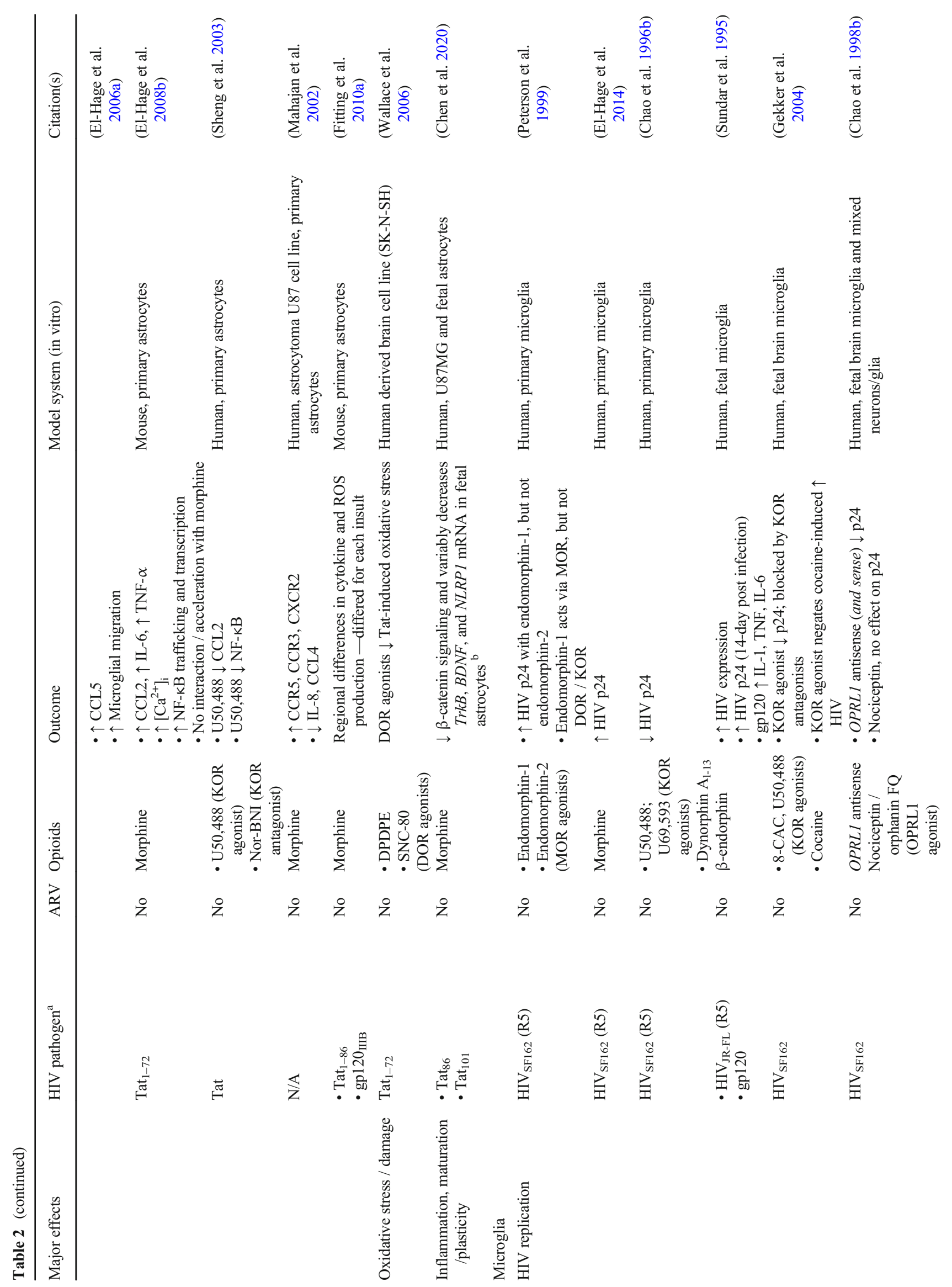




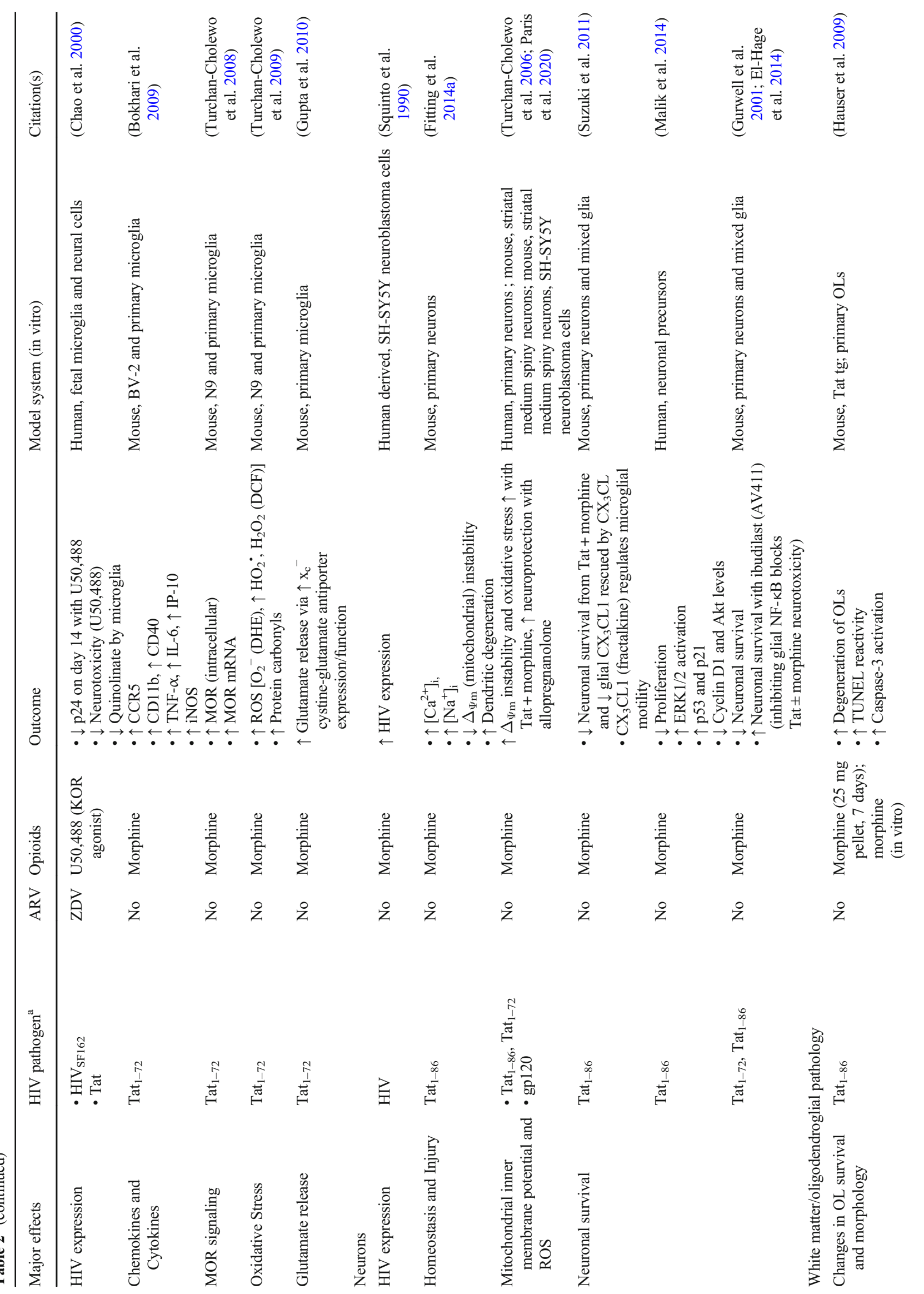




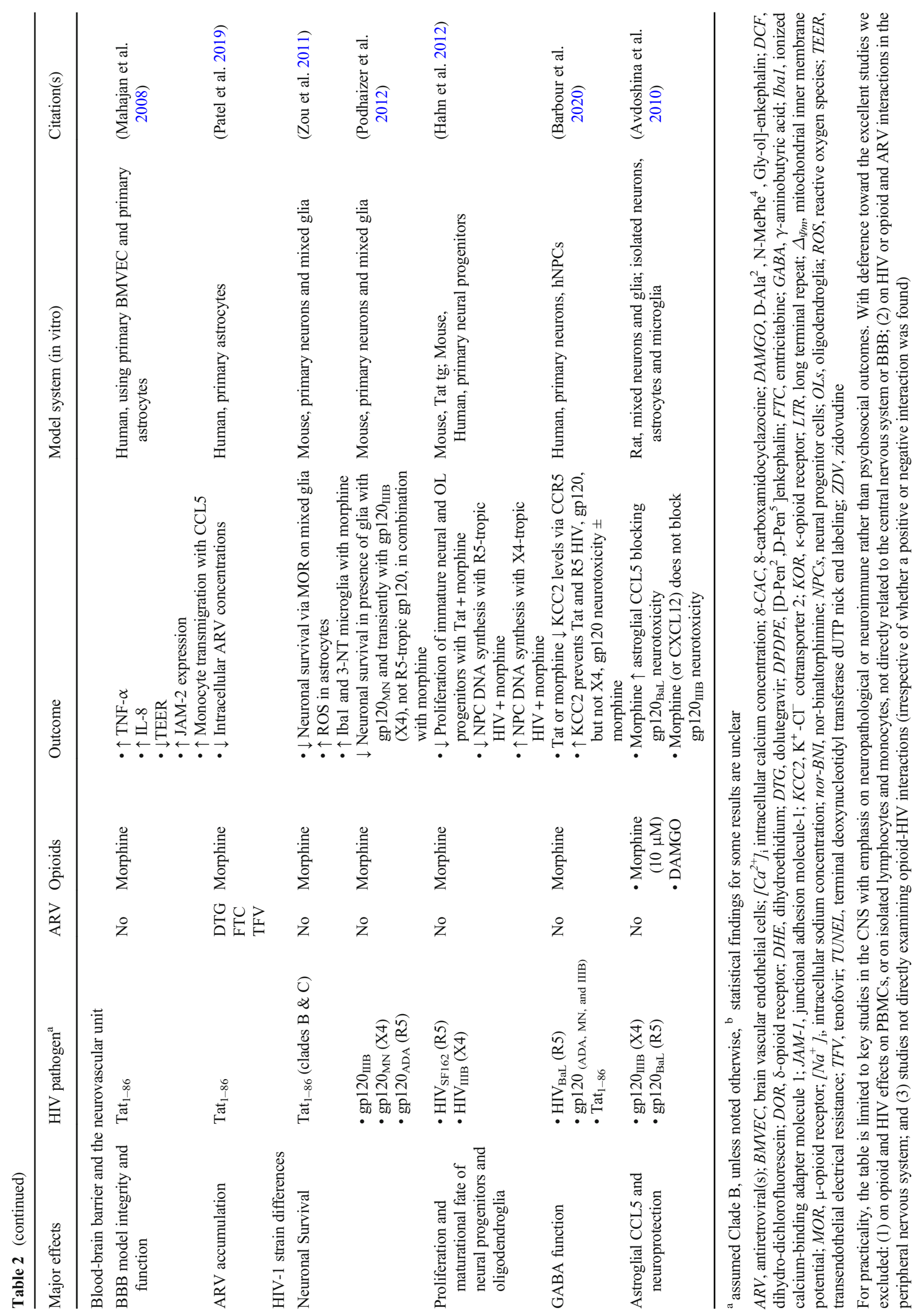


subunit (Mathews et al. 2008) is presumed operative here (Fig. 2).

Glial-derived neuronal injury is not unidirectional. Neuronal damage-associated molecular patterns (DAMPs) and dysfunction can trigger both infected and uninfected glia to become reactive, resulting in further neuronal damage and escalating pathology. Neuronal injury can reactivate HIV in latently infected microglia (Alvarez-Carbonell et al. 2019). While the events underlying the disruption of neuronalmicroglial activation that trigger the emergence of latent HIV are unclear, the induction of HIV expression appears to involve the production of DAMPs by injured neurons and can be turned "on", e.g., by methamphetamine-induced sigma-1 ( $\sigma 1)$ receptor activation, TNF- $\alpha$ and IL- $1 \beta$, and TLR3 activation can be turned "off" by CX3CL1/fractalkine or glucocorticoid receptor activation (Alvarez-Carbonell et al. 2017, 2019).

\section{Neural Systems Selectively Disrupted by Opiate and HIV Interactions}

\section{Blood-Brain Barrier and the Neurovascular Unit}

Despite growing evidence on how opiates and HIV interact to impact the neuropathology of HIV, little is known about their interactive effects on the blood-brain barrier (BBB). BBB integrity and function are critical for maintaining CNS homeostasis, and mediating neuroimmune interactions with the periphery and drug delivery into the CNS. HIV and many individual HIV proteins can breakdown the BBB disrupting tight junction proteins (Dallasta et al. 1999; Boven et al. 2000; Andras et al. 2003; Mahajan et al. 2008; Banerjee et al. 2010; Gandhi et al. 2010; Xu et al. 2012; Patel et al. 2017) and decreasing transendothelial electrical resistance (TEER) (an in vitro measure of barrier integrity) (Mahajan et al. 2008; Gandhi et al. 2010; Mishra and Singh 2014; Patel et al. 2017), with resultant paracellular "leakage" of compounds/current between compromised barrier endothelial cells (Mahajan et al. 2008; Gandhi et al. 2010; Wen et al. 2011; McLane et al. 2014; Leibrand et al. 2017, 2019). Although opioids can also impair the BBB through alterations in tight junction proteins and/or increased paracellular flux (Baba et al. 1988; Mahajan et al. 2008; Wen et al. 2011; Leibrand et al. 2019), others have found that it is morphine withdrawal, not the continued exposure to morphine, that most greatly disrupts BBB integrity (Sharma and Ali 2006). In addition to perturbing paracellular dynamics, morphine may also alter the expression and/or function of drug efflux proteins, such as P-glycoprotein (P-gp). Sub-chronic and chronic morphine exposure is reported to increase P-gp expression and/or function (Aquilante et al. 2000; Mahajan et al. 2008; Yousif et al. 2008; Leibrand et al. 2019). Alternatively, other investigators report no changes in P-gp with chronic exposure (Chaves et al.
Fig. 1 Opioids exacerbate HIV-1-induced CNS inflammation, in part, by augmenting CCL5-dependent increases in CCL2 - key sites of opioid-HIV convergent interactions in glial inflammatory signaling cascades. Subpopulations of striatal glial fibrillary acidic protein (GFAP)immunoreactive astrocytes in wildtype mice normally express CCR2 immunoreactivity (a-b; arrows), CCL2 (c; arrow), or $\mu$-opioid receptor (MOR) $(\mathbf{d}$; arrows) immunoreactivity (scale bars $\mathbf{a}-\mathbf{b}=25 \mu \mathrm{m}$; $\mathbf{c}-\mathbf{d}=$ $15 \mu \mathrm{m})$. CCR2 deletion (-/-) significantly reduces HIV-1 Tat \pm morphineinduced increases in GFAP+ astroglia (e) and F4/80+ macrophages/microglia (f) compared to wild type $(+/+)$ mice at sites near $(300 \pm 100 \mu \mathrm{m})$ the site of Tat injection ( ${ }^{*} p<0.05$ vs. wild type mice) (see, El-Hage et al. 2006a). In wild-type mice, Tat \pm morphine administration markedly increases the proportion of CCL2 immunoreactive astrocytes (g) or macrophages/ microglia (h) $\left[{ }^{*} p<0.05\right.$ vs. other groups in wild-type or CCL5(-/-) mice; ${ }^{\mathrm{b}} p<0.05$ vs. vehicle- or Tat plus morphine-treated wild-type mice; ${ }^{*} p<0.05$ vs. equivalent treatment in wild-type mice], while in CCL5 null mice, significant increases in CCL2 immunoreactivity were only seen in macrophages/microglia co-exposed to Tat and morphine $\left({ }^{\S} p<0.05\right.$ vs. vehicle injected CCL5 knockout mice) (see, El-Hage et al. 2008a). CCL5 expression in striatal GFAP-immunoreactive astrocytes (arrows) increases following Tat injections (i, $\mathbf{j}$ ) compared to wild-type control mice (not shown) (El-Hage et al. 2008a). Opioids exacerbate HIV-1-induced CNS inflammation, in part, by increasing CCL5 and augmenting CCR5dependent increases in CCL2 production by astrocytes resulting in the activation and recruitment of microglia/macrophages and spiraling inflammation $(\mathbf{k})$. Additional factors likely mediate the proinflammatory cascade, but these are less well substantiated (?). Moreover, autocrine and reciprocal paracrine (astroglial $\leftrightarrow$ macrophage/microglial) intercellular, feedback amplification mechanisms from macrophages/microglia are likely to be operative (dashed red arrow) (also see, Kang and Hebert 2011) and occur elsewhere within the cascade (not shown); effects of HIV-1 Tat/HIV, red arrows; sites of opioid convergence, blue arrows; pro-BDNF:mature BDNF (mBDNF) ratio (Kim et al. 2018). (a-f) Modified and reprinted with

2016), while some see increases upon morphine withdrawal (Yousif et al. 2012; Chaves et al. 2016). Alterations in drug transport proteins would impact the central accumulation and efficacy of therapeutic drugs that are their substrates.

Using a primary human brain microvascular endothelial cell (BMEC) and astrocyte co-culture model, Mahajan et al. (2008) were among the first to demonstrate that co-exposure to morphine and HIV-1 Tat resulted in greater increases in TNF- $\alpha$ and IL- 8 levels and decreases in barrier tightness (measured by TEER) than either morphine or Tat alone. Morphine and Tat co-exposure also additively increased JAM-2, while zonula occludens-1 (ZO-1) levels were decreased by morphine or by Tat individually, and occludin protein levels were decreased by morphine alone but not Tat (Mahajan et al. 2008). Using the inducible Tat transgenic mouse model, Leibrand et al. (2019), also demonstrated that HIV-1 Tat and morphine act independently to disrupt BBB integrity. In these studies, morphine, and to a lesser extent Tat, exposure increased the leakage of fluorescently labeled dextrans from the circulation into the brain (Leibrand et al. 2017, 2019) (Fig. 3). Morphine exposure decreased the penetration of select ARVs in the brain, in a region-specific manner (Leibrand et al. 2019) (Fig. 3). Morphine exposure also resulted in increased expression and function of the drug 

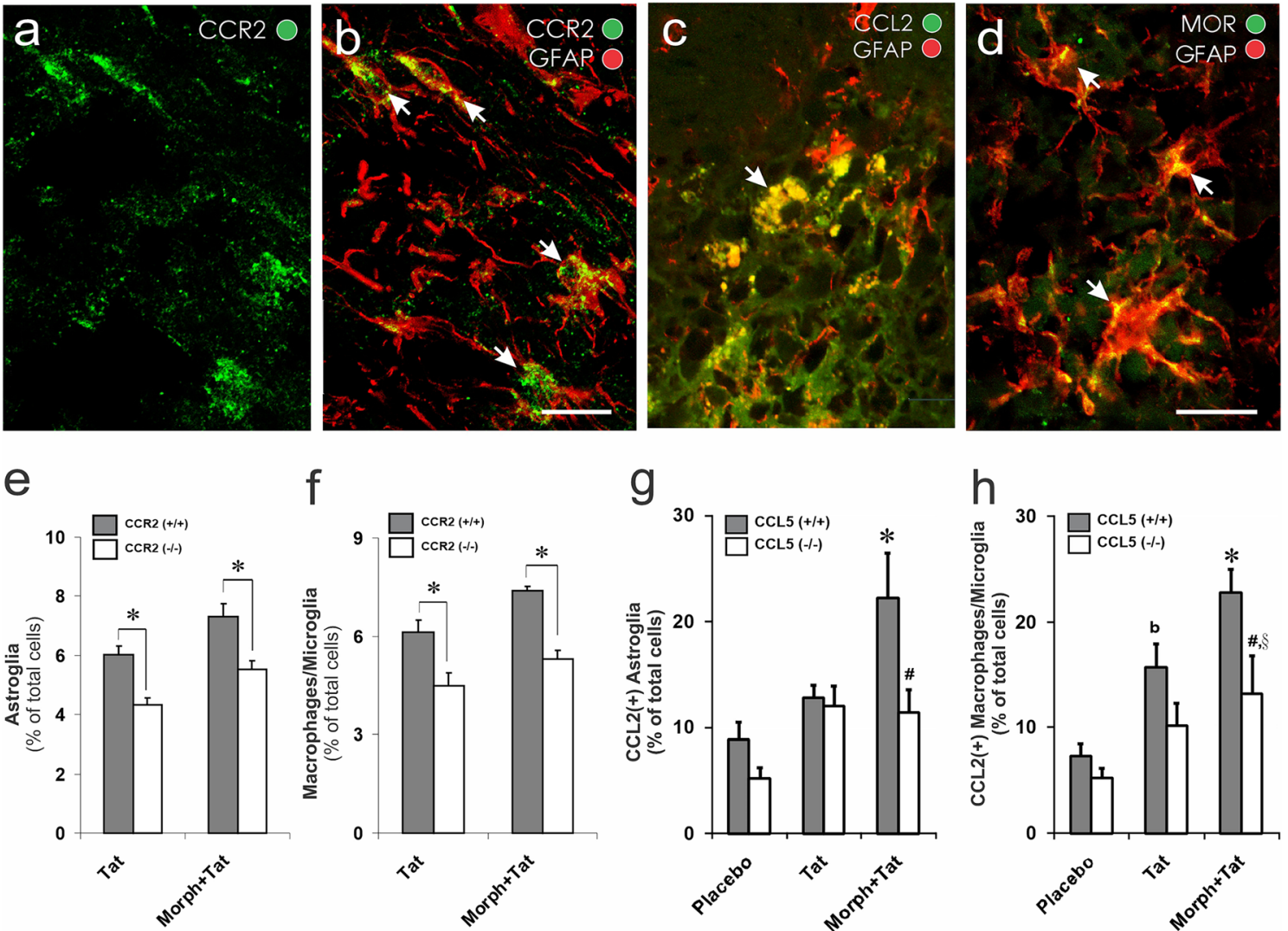

$f$

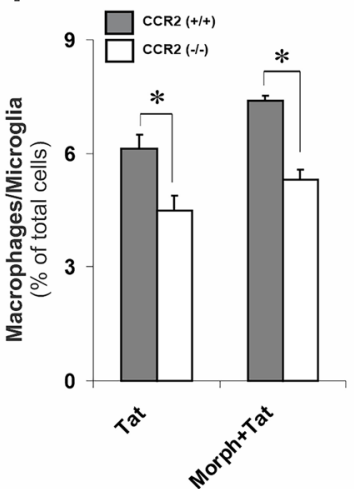

g

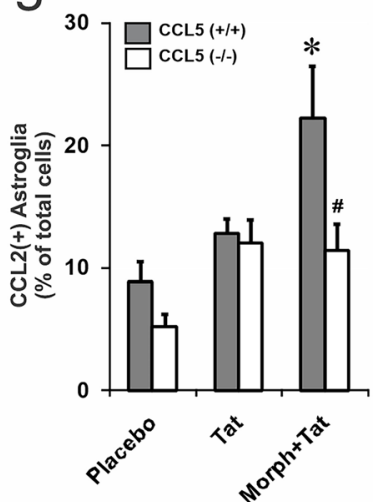

h

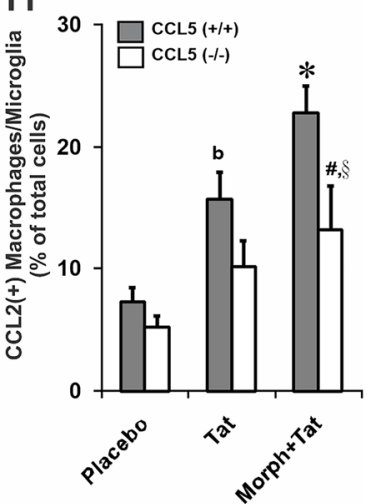

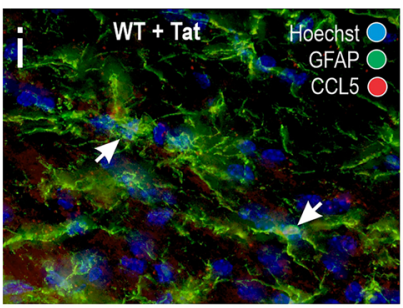

K

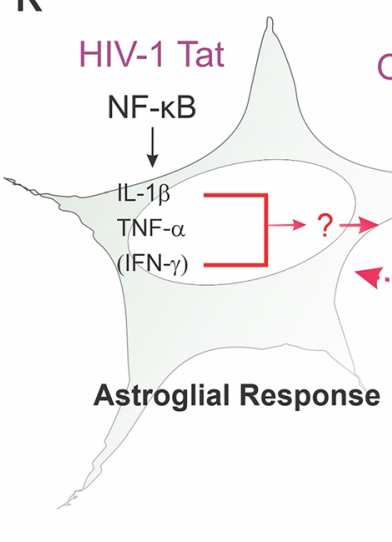

Opiates

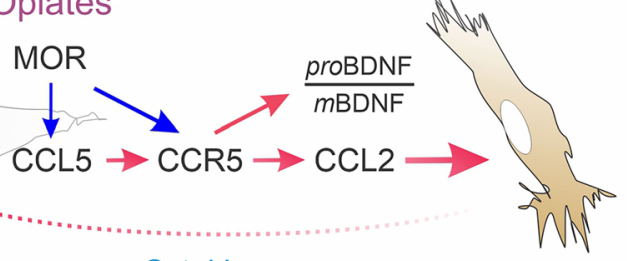

Cytokines

Microglial

recruitment \&

activation

efflux transport protein, P-gp, suggesting a mechanism by which morphine decreased the ARV concentrations (Leibrand et al. 2019). This finding suggests that morphine exposure could impact the efficient delivery of any therapeutic drug that is a substrate of P-gp into the CNS. Future research should also investigate morphine's impact on other drug transport proteins important for ARV delivery to the brain.

HIV, HIV-1 viral proteins, and opiate-induced barrier dysfunction is associated with increased infiltration of monocytederived macrophages (MDMs) into the brain. Enhanced influx of peripheral (infected) macrophages into the brain can serve to replenish viral reservoirs and further promote neuroinflammation. Several studies have examined the individual impact of HIV, Tat, or morphine on monocyte adhesion or migration into the CNS (Nottet et al. 1996; Wu et al. 2000; Fischer-Smith et al. 2001; Pello et al. 2006; Williams et al. 2013a, 2014; Strazza et al. 2016; Leibrand et al. 2017; Chilunda et al. 2019). However, fewer studies have examined the combined effects of HIV/Tat and opiates. Co-exposure of HIV-1 Tat and morphine on astrocytes increases the production of chemoattractants, primarily CCL2 and CCL5, and increases microglial migration. These effects were inhibited by MOR blockade (El-Hage et al. 2006b). Co-exposure of Tat and 

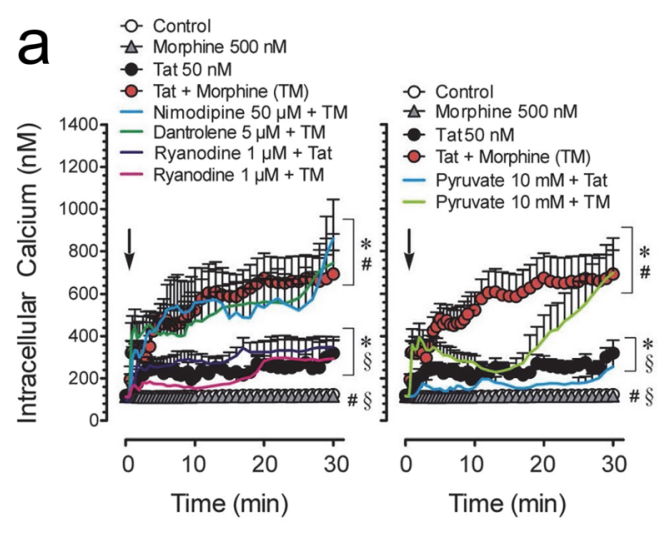

b

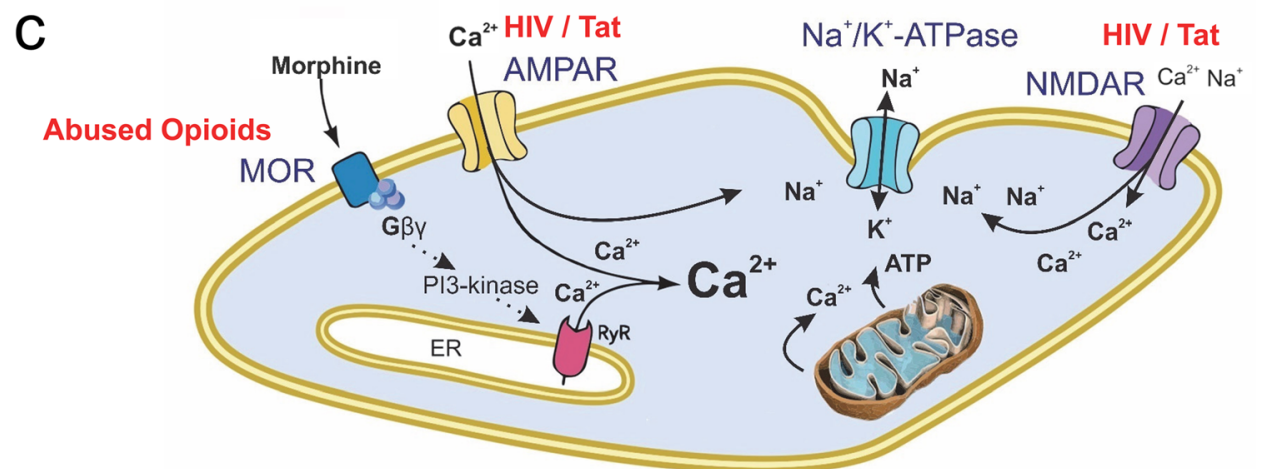

Fig. 2 Morphine exacerbates the excitotoxic effects of HIV Tat by mobilizing $\mathrm{Ca}^{2+}$ from ryanodine (RyR)-sensitive internal stores. (a) Tatinduced increases in $\left[\mathrm{Ca}^{2+}\right]_{\mathrm{i}}$ were not attenuated by ryanodine, whereas ryanodine and pyruvate attenuate combined Tat and morphine-induced increases in $\left[\mathrm{Ca}^{2+}\right]_{\mathrm{i}}$. Nimodipine (L-type $\mathrm{Ca}^{2+}$ channel blocker) and dantrolene did not show any effects. (b) Average $\left[\mathrm{Ca}^{2+}\right]_{\mathrm{i}}$ over $10 \mathrm{~min}$ indicated ryanodine significantly blocked combined Tat and morphineinduced increases in $\left[\mathrm{Ca}^{2+}\right]_{i}$, whereas no effects were noted for nimodipine, dantrolene, or pyruvate. ${ }^{*} p<0.05$ vs. control, ${ }^{\#} p<0.05$ vs. Tat $50 \mathrm{nM},{ }^{\S} p<0.05$ vs. TM, TM: Tat $50 \mathrm{nM}+$ Morphine $500 \mathrm{nM}$. (c) Summary of HIV-1 Tat and morphine interactive neuronal injury in striatal medium spiny neurons. Combined Tat and morphine promotes structural and functional defects in dendrites via $\alpha$-amino-3-hydroxy-5- methyl-4-isoxazolepropionic acid receptors (AMPAR), $N$-methyl-Daspartic acid receptors (NMDAR), and MOR, causing influxes of $\mathrm{Na}^{+}$ and/or $\mathrm{Ca}^{2+}$, compensatory increases in $\mathrm{Na}^{+} / \mathrm{K}^{+}$-dependent ATPase activity, and a rapid loss in ATP mobilization with an inability to extrude excess $\mathrm{Na}^{+}$via $\mathrm{Na}^{+} / \mathrm{K}^{+}$-ATPase caused by mitochondrial hyperpolarization. Dysregulation of $\left[\mathrm{Ca}^{2+}\right]_{\mathrm{i}}$ homeostasis by combined Tat and morphine appears to be mediated downstream of $\left[\mathrm{Na}^{+}\right]_{\mathrm{i}}$ at the level of calcium mobilization, which in turn appears to be regulated via ryanodine (RyR)-sensitive sites, and enhanced by morphine exposure likely via MOR-dependent stimulation of PI3-kinase and $\mathrm{Ca}^{2+}$ mobilization via the $G \beta \gamma$ protein subunit. (a-b) Modified and reprinted with permission from Fitting et al. (2014a)

concentrations. Collectively, these changes serve to maintain HIV infection within the brain (see Fig. 4; Tables 1 and 2).

\section{White Matter/Oligodendroglial Pathology}

HIV can cause white matter damage (Gosztonyi et al. 1994; Langford et al. 2002; Xuan et al. 2013) even with less severe forms of HAND (Chen et al. 2009; Leite et al. 2013; Correa et al. 2015). Diffusion tensor magnetic resonance imaging (DTI) demonstrates white matter damage early in HAND (Ragin et al. 2004; Stubbe-Drger et al. 2012; Leite et al. 2013; Correa et al. 2015). White matter deficits are associated with cognitive impairment, including shortfalls in memory (Ragin et al. 2005), executive function (Correa et al. 2015), motor speed (Wu et al. 2006; Stubbe-Drger et al. 2012), and perhaps depression (Schmaal and van Velzen 2019). 

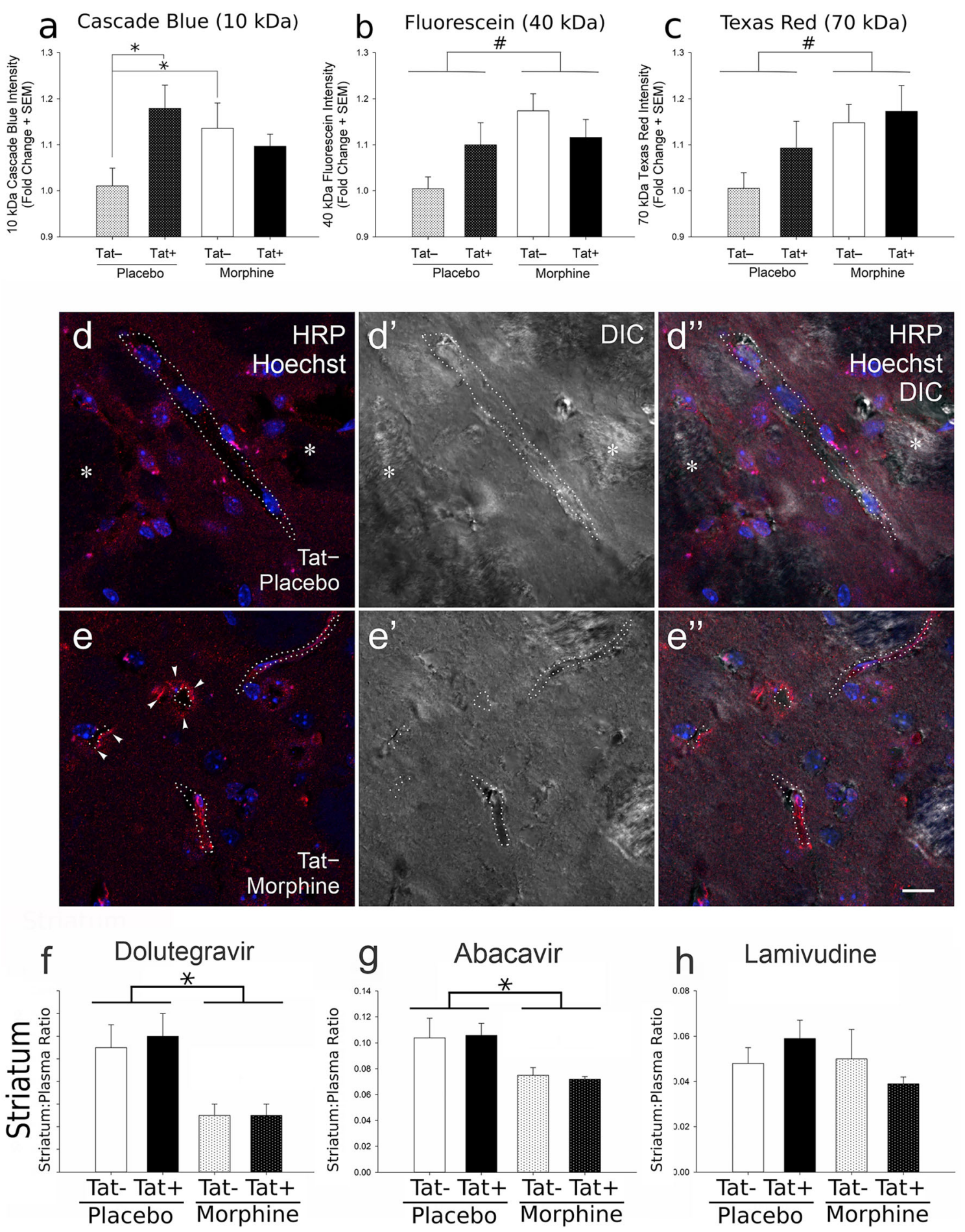

Preclinical studies in simian immunodeficiency virus- (SIV-) infected rhesus macaques (Marcario et al. 2008) and HIVinfected humanized mice (Boska et al. 2014) support the clinical findings. Injury to oligodendrocytes (OLs) can occur very early in the disease (see review, Liu et al. 2016b). Viral proteins, including Tat, gp120, and Nef, have been implicated in
OL injury in vitro (Kimura-Kuroda et al. 1994; Bernardo et al. 1997; Radja et al. 2003; Nukuzuma et al. 2012; Zou et al. 2015), and in animal models in vivo (Radja et al. 2003; Hauser et al. 2009; Zou et al. 2015). Importantly, Tat has been detected in OLs in the brains of AIDS patients (Del Valle et al. 2000). 
Fig. 3 Effects of HIV-1 Tat and morphine on BBB leakiness and on antiretroviral brain concentrations. After 14 days of Tat induction, there was a significant increase in the $10 \mathrm{kDa}$ (Cascade Blue $囚)$ tracer leakage into the brain in Tat + placebo as compared to Tat - placebo mice $\left({ }^{*} p<\right.$ 0.05 ) and in Tat - mouse brains upon exposure to morphine as compared to Tat - placebo mice $\left({ }^{*} p<0.05\right)(\mathbf{a})$. There was a significant main effect of morphine, resulting in reduced integrity of the BBB and increased leakage of the higher molecular weight $(40 \mathrm{kDa}$ and $70 \mathrm{kDa})$ tracers in morphine-exposed groups as compared to the those groups (Tat + and Tat - together) not exposed to morphine (placebo) ${ }^{\#} p<0.05$; significant main effect of morphine) $(\mathbf{b}, \mathbf{c})$. Data represent the fold change in mean fluorescence intensity \pm SEM; $n=8$ Tat - /placebo, $n=$ 6 Tat+/placebo, $n=9$ Tat-/morphine, and $n=7$ Tat+/morphine mice. Additionally, morphine exposure increased horseradish peroxidase (HRP) extravasation from the vasculature into the perivascular space and/or parenchyma in the striatum (d, e). HRP antigenicity was detected by indirect immunofluorescence (red) in tissue sections counterstained with Hoechst 33342 (blue) to reveal cell nuclei and visualized by differential interference contrast (DIC)-enhanced confocal microscopy. HRP extravasation into the striatal perivascular space/ parenchyma was especially prevalent in morphine-exposed mice (arrowheads; left-hand panels in e versus d). The dotted lines (……....) indicate the approximate edge of the capillaries/post-capillary venules; while intermittent dotted lines $(\cdots \cdots \cdot)$ indicate the approximate edge of a partly sectioned blood vessel that appears partially outside the plane of section. The asterisks $(*)$ indicate white matter tracts within the striatum. Representative samples from $\geq n=4$ mice per group. All images are the same magnification. Scale bar $=10 \mu \mathrm{m}$. Antiretroviral tissue-to-plasma ratios in striatum ( $\mathbf{f}-\mathbf{g})$. Irrespective of Tat exposure, morphine significantly reduced the levels of dolutegravir (f) and abacavir (g), but not lamivudine (h), within the striatum, as compared to placebo. (* $p<0.05$; main effect for morphine). Data represent the tissue-to-plasma ratios \pm SEM sampled from $n=9$ Tat-/placebo, $n=9$ Tat+/placebo, $n=6$ Tat $-/$ morphine, and $n=8$ Tat $+/$ morphine mice. $(\mathbf{a}-\mathbf{h})$ Modified and reprinted with permission from Leibrand et al. (2019)

HIV likely damages OLs through both direct and indirect actions. OLs lack CD4, and reports of OL infection by HIV are variable (Esiri et al. 1991; Albright et al. 1996; Wohlschlaeger et al. 2009); thus, HIV infection of OLs is unlikely a major avenue of OL or white matter damage (discussed below). Alternatively, bystander damage to OLs through the production of "virotoxins" and "cellular toxins" (Nath 1999) by infected neighboring cells is more likely to be operative (Hauser et al. 2009; Zou et al. 2015; Jensen et al. 2019; Zou et al. 2019). ARVs also contribute to OL cytotoxicity (Jensen et al. 2015; Festa et al. 2019; Jensen et al. 2019). HIV-1 Tat directly induces damage in isolated OLs through $\alpha$ amino-3-hydroxy-5-methyl-4-isoxazolepropionic acid (AMPA)/ $N$-methyl-D-aspartic acid (NMDA) receptor-dependent mechanisms (Zou et al. 2015) and is also associated with abnormal Kv1.3 activity (Liu et al. 2017). Immature OLs are preferentially targeted by Tat compared to differentiated OLs (Khurdayan et al. 2004; Hahn et al. 2012; Zou et al. 2015, 2019). While the reasons why immature OLs are more susceptible to Tat are unclear, unlike mature OLs, Tat preferentially upregulates GSK-3 $\beta$ signaling in undifferentiated OLs by inhibiting $\mathrm{Ca}^{2+} /$ calmodulin-dependent protein kinase II $\beta$ (CaMKIIß) (Zou et al. 2019).
Opioid abuse by itself can result in demyelination, leukoencephalopathy, and lesions in white matter (Offiah and Hall 2008; Eran and Barak 2009; Morales Odia et al. 2010; Bora et al. 2012; Li et al. 2013), and the degree of myelin disruption correlates with the duration of opiate dependence (Ivers et al. 2018). Chronic oxycodone exposure in rats causes some axonopathies and reduces the size of axonal fascicles, decreases myelin basic protein levels, and causes the accumulation of amyloid- $\beta$ precursor protein (APP) (Fan et al. 2018). Most preclinical studies have examined the effects of opioids and opioid receptor blockade on OL maturation and/or the timing of myelination (Hauser et al. 1993; Knapp et al. 1998; Stiene-Martin et al. 2001; Sanchez et al. 2008; Knapp et al. 2009; Vestal-Laborde et al. 2014). OLs can transiently express MORs and other opioid receptor types (Knapp et al. 1998; Tryoen-Toth et al. 2000; Knapp et al. 2001; Stiene-Martin et al. 2001). Selective MOR and possibly KOR activation can directly modulate the growth of OLs in vitro (Knapp and Hauser 1996; Knapp et al. 1998, 2001).

Despite long-standing evidence of white matter damage early during the infection even in asymptomatic PWH (Price et al. 1988; Gray et al. 1996; Chen et al. 2009; Stubbe-Drger et al. 2012; Jensen et al. 2019), few studies have examined how opiate exposure affects OLs and myelin in neuroHIV (Tables 1 and 2). Increased demyelination is reported in SIV-infected rhesus macaques chronically treated with morphine (4× daily, up to 59 weeks) (Marcario et al. 2008). Specifically, morphine-treated SIV macaques developed more subtle, focal, dysmyelinating lesions, with accumulations of macrophages in areas of myelin loss (Marcario et al. 2008), as well as accompanying gliosis (Marcario et al. 2008; RiveraAmill et al. 2010a; Bokhari et al. 2011). Morphine exposure increased degeneration of OLs in Tat+ mice, which was accompanied by elevations in caspase- 3 activation and TUNEL reactivity in OLs and reversible by naloxone or naltrexone, respectively (Hauser et al. 2009). Although OLs can express MOR both in vivo (Stiene-Martin et al. 2001) and in vitro (Hauser et al. 2009), it remains unclear the extent to which MOR activation in OLs directly mediates HIV pathogenesis.

\section{Neural Progenitors as an HIV Reservoir and Target for Opioids}

Even though neural progenitors (Krathwohl and Kaiser 2004; Lawrence et al. 2004; Rothenaigner et al. 2007; Schwartz et al. 2007; Balinang et al. 2017), neuroblast cell lines (Ensoli et al. 1994; Rothenaigner et al. 2007), and/or immature astroglia (Atwood et al. 1993; Tornatore et al. 1994; Barat et al. 2018) can harbor HIV infection (reviewed by Hauser and Knapp 2014; Putatunda et al. 2019), the degree to which they are a source of active infection or serve as a latent viral reservoir (Blankson et al. 2002; Bruner et al. 2019) by retaining intact proviral DNA within incipient macroglial progeny is uncertain. In fact, spurious reports of HIV-infected adult 


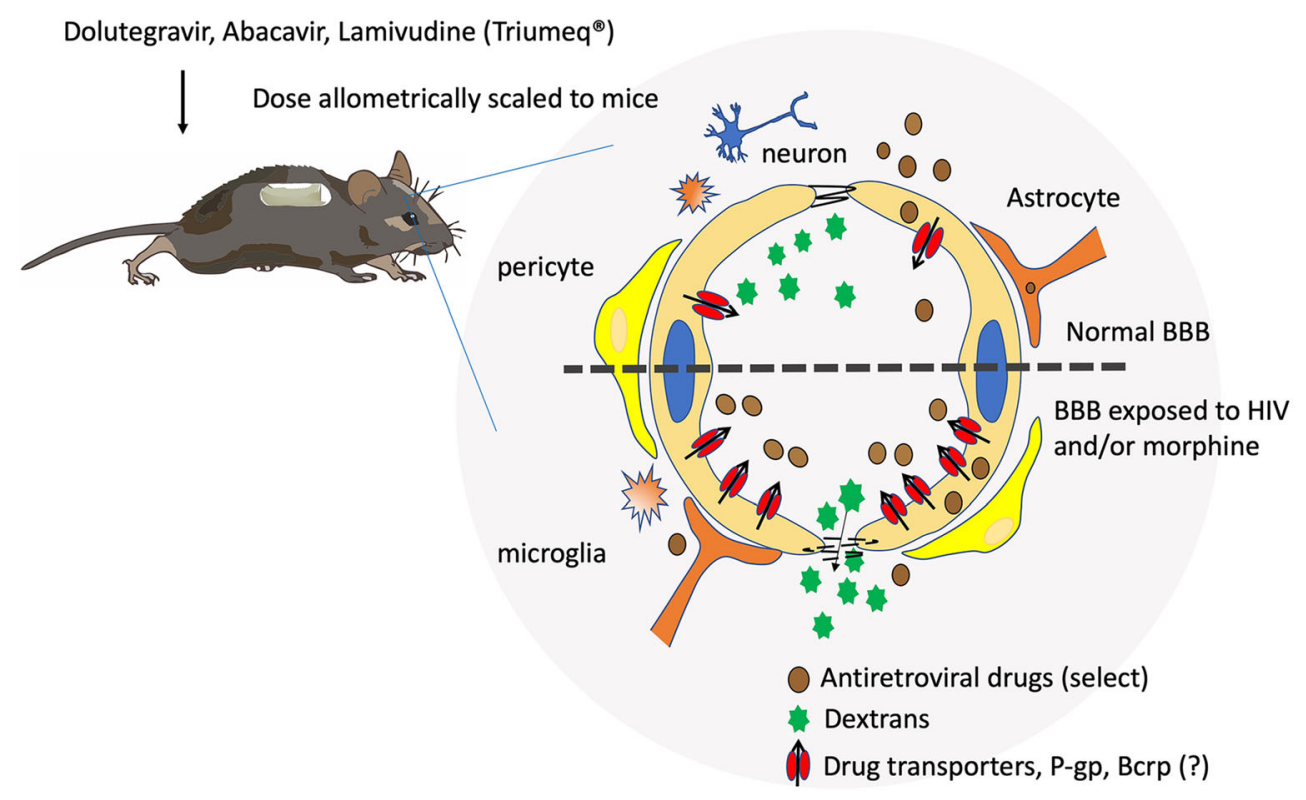

Fig. 4 Schematic representation of the blood-brain barrier and other components of the neurovascular unit. Under normal conditions (represented above the dotted line), tight junctions are intact which restricts the leakage of paracellular, typically small hydrophilic, compounds, across the barrier and into the brain. Additionally, there is a basal expression of efflux transporters, such as P-glycoprotein (P-gp), which effluxes substrates out of the brain, serving to restrict overall accumulation within the brain. In the setting of HIV and opiate

neurons (Torres-Munoz et al. 2001; Canto-Nogues et al. 2005) may result from the retention of proviral genes that integrated into pluripotent neural progenitors or neuroblasts at earlier stages during maturation. Importantly, prolonged exposure to opioids can increase the production of HIV in human neural progenitor cells (hNPCs). Exposure of R5tropic $\mathrm{HIV}_{\mathrm{BaL}}$-infected hNPCs to morphine continuously for $21 \mathrm{~d}$ increased viral production compared to $\mathrm{HIV}_{\mathrm{BaL}}$ infection alone in vitro (Balinang et al. 2017).

Besides being able to infect hNPCs, HIV may also affect their maturation and the fate of neural stem cells. That HIV or gp120 can inhibit adult neurogenesis (Okamoto et al. 2007; Lee et al. 2013; Putatunda et al. 2018) has been the topic of past reviews (Schwartz and Major 2006; Venkatesan et al. 2007; Peng et al. 2008, 2011; Ferrell and Giunta 2014; Hauser and Knapp 2014; Putatunda et al. 2019). How HIV inhibits the self-renewal, tripotential differentiation, and survival of neural progenitors/stem cells or the genesis of adult neurons in the subgranular zone (SGZ) of the dentate gyrus is uncertain. HIV and gp120 [via actions at the same chemokine receptor(s) (Tran and Miller 2005; Li and Ransohoff 2008)] are proposed to modulate the adult neurogenesis via Notch (Fan et al. 2016), by obstructing a cell cycle checkpoint via the activation MAPK-activated protein kinase 2 and Cdc25B/ C (Okamoto et al. 2007), or through signaling by plateletderived growth factor BB (Chao et al. 2014) or BDNF (Lee et al. 2013). The extent that HIV regulates the genesis of exposure (represented below the dotted line), there is a breakdown of the tight junction proteins and increased leakage of paracellular compounds into the brain. Additionally, opiate exposure increases efflux transporter expression, including P-gp and potentially breast cancer resistance protein (Bcrp), thereby restricting overall brain penetration of drugs (like many antiretroviral drugs) which are substrates for these transporters and in response to HIV and/or opioid exposure.

neural progenitors within the subventricular zone of the developing CNS through similar mechanisms as in the adult SGZ of the dentate gyrus is uncertain - even though HIV disrupts the generation of neurons and glia during maturation or in adults. For example, MAPK/ERK1/2 enhances p53- and p21-dependent downregulation of cyclin D1 hindering progression through the $\mathrm{G}_{1}$ phase of the cell cycle in hNPCs (Mishra et al. 2010; Malik et al. 2014). Importantly, opioids too can affect the genesis of neurons and glia during maturation or in the adult directly via convergent pathways (Hauser and Knapp 2018; Kibaly et al. 2018) suggesting yet another site of opioid and HIV interactions in dysregulating the creation and fate of new neurons and glia.

Few studies have examined the interplay between opioids, neural progenitors and HIV/HIV proteins. Sustained exposure $(4 \mathrm{~d})$ to morphine $(500 \mathrm{nM})$ and $\mathrm{Tat}_{1-72}(100 \mathrm{nM})$ decreased the viability of MOR-expressing striatal glial precursors, and to a lesser extent astrocytes, and this coincided with caspase-3 activation (Khurdayan et al. 2004). By contrast, comparably administered morphine or Tat alone was sufficient to decrease the viability of immature glia/glial progenitors in spinal cord cultures, while Tat and morphine failed to interact (Buch et al. 2007). Collectively, these findings were the first to indicate that opioid and/or Tat could enhance programmed cell death in subpopulations of glial precursors in a developmentally regulated and region-dependent manner (Khurdayan et al. 2004; Buch et al. 2007). In human glial progenitors, co- 
administering morphine $(500 \mathrm{nM})$ increased the antiproliferative effects of Tat $(12-48 \mathrm{~h})$ or conditioned medium from HIV-1 ${ }_{\text {SF } 162}$-infected MDMs $(12 \mathrm{~h})$, while paradoxically reversing the antiproliferative effects from HIV-1 $1_{\text {IIIB }}$ conditioned medium (12 h) (Hahn et al. 2012). In these studies, Tat or HIV exposure reduced the proliferation of Sox $2+$ and Olig2+ undifferentiated glial and oligodendroglial progenitors, respectively, while progenitor viability was unchanged (Hahn et al. 2012). In human neural progenitor cells (hNPCs), sustained infection with R5-tropic HIV $_{\mathrm{BaL}}$ increased the proliferation and premature differentiation of hNPCs into both neurons and astrocytes, and both measures were significantly enhanced by morphine co-exposure (Balinang et al. 2017). Importantly, immunoneutralizing antibodies (Hahn et al. 2012) or the selective antagonist, maraviroc (Balinang et al. 2017), were able to significantly attenuate the consequences of R5-tropic HIV infection on hNPC differentiation and fate confirming a direct role of CCR5 in these processes. Lastly, decreases in the proliferation of hNPCs seen with morphine and Tat are, in part, regulated by ERK1/2-dependent increases in p53 and p21 expression (Malik et al. 2014) and can be modulated by PDGF BB suggesting a possible therapeutic target (Malik et al. 2011). Thus, morphine can exaggerate R5-tropic HIV-induced alterations in the maturation and fate of human and rodent NPCs, thereby further disrupting the balance of neural cell types and CNS function.

\section{Matters Needing Further Consideration in Opioid and HIV Comorbidity}

The interplay of complex host and viral genetic differences is likely to play a huge role in determining pathologic outcomes in PWH. For example, differences in HIV strains/variants (Rao et al. 2013) and human/host genetic variability (Proudnikov et al. 2012), pharmacokinetics (Kuhlman et al. 1996; Eap et al. 2002; Elkader and Sproule 2005; Kharasch 2017; Kringen et al. 2017), and sex (Zubieta et al. 2002; Taylor and Davies 2010; Venuto et al. 2014; Marinho et al. 2019) all contribute to variability in responsiveness. The following subsections will focus on key factors affecting opioid and HIV comorbidity.

\section{HIV-1 Genetics}

Genetic differences among HIV-1 variants have a significant impact on HIV transmission, disease progression, as well as the response to ARV therapy (see reviews, Geretti 2006; Taylor et al. 2008; Tyor et al. 2013; Tables 1 and 2). PrecART studies provide substantial evidence that HIV clade differences can influence HAND (Gupta et al. 2007; Sacktor et al. 2009; Boivin et al. 2010; McArthur et al. 2010; Rao et al.
2013), with HAND severity being highest for clade D and B strains, followed by $\mathrm{C}$ and A clades (Tyor et al. 2013). These findings are supported by preclinical studies in which clade $\mathrm{B}$ or clade $\mathrm{C} \mathrm{HIV-infected} \mathrm{macrophages} \mathrm{were} \mathrm{intracranially}$ injected into severe combined immunodeficient mice (SCID) mice. Exposure to clade B isolates induced more severe memory deficits, as well as greater astrogliosis and neuronal damage (Rao et al. 2008, 2013). In another example, the Tat dicysteine motif (CC) at positions 30 and 31, which is commonly found in clade B isolates, appears to worsen HAND (Mishra et al. 2008; Rao et al. 2013) and has been studied extensively in vitro (Ranga et al. 2004; Rao et al. 2008; Zou et al. 2011; Krishnan and Chatterjee 2015). Clade B Tat is more intrinsically cytotoxic to primary neurons in vitro than clade C Tat (Li et al. 2008; Campbell et al. 2011; Zou et al. $2011)$, resulting in increased proinflammatory cytokine production (e.g., IL-6 and TNF- $\alpha$ ) (Gandhi et al. 2009) and monocyte recruitment/migration into the brain (Ranga et al. 2004; Rao et al. 2008), and increased disruption of the BBB (Gandhi et al. 2010). Similarly, the production of the inflammatory mediators prostaglandin $\mathrm{E}_{2}$ and the thromboxane $\mathrm{A}_{2}$ receptor by astrocytes is more significantly increased by clade B than clade C gp120 (Samikkannu et al. 2011). Sequence and structural alterations in gp120 have been demonstrated between clades B and C (Gnanakaran et al. 2007) and potentially contribute to these observed differences.

When considering effects of HIV clade variants in the presence of opioids, the overall toxicity in MSNs seen with clade C Tat (30\% neuronal losses) was considerably less than with clade B (70\% losses) (Zou et al. 2011). Although clade B HIV predominates in Western countries, future clinical longitudinal studies are necessary that employ HIV clade testing in HIV-1 infected opioid users to confirm the hypothesis that opioid interactive effects on HAND pathogenesis depend on the HIV clade assessed.

Besides HIV genetic diversity, differences in HIV tropism add another level of complexity. Morphine interactions can differ significantly between X4 and R5tropic gp120 variants depending on the outcome measure (El-Hage et al. 2011b; Podhaizer et al. 2012; Balinang et al. 2017; Kim et al. 2018). Increased infectivity in the presence of morphine was noted for the

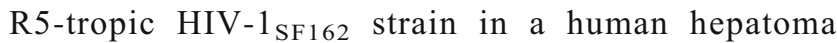
Huh7.5.1 cell line model, whereas the infectivity rate with the X4-tropic HIV-1 LAI/IIIB strain was unaffected by morphine (El-Hage et al. 2011b).

To date, no clinical studies have assessed whether opioid interactions with R5- or R4-preferring HIV strains differentially impact the severity of HAND. However, the findings from preclinical studies indicate that HIV-1 strain-specific 
differences are critical determinants in shaping both the timing and pattern of neurotoxic interactions with opioid drugs.

\section{Host Genetics}

Host genetic variability can be a major determinant in individual susceptibility to HIV infectivity and may influence neuroHIV progression in the context of opiate co-exposure. The importance of CCR5 for HIV infectivity and polymorphisms in this gene are well established. Individuals who are homozygous in the CCR5 gene (CCR5 $\Delta 32)$ are highly resistant to infection by CCR5- (R5-) tropic HIV as demonstrated by individuals heterozygous for CCR5 $\Delta 32$ who display partial resistance to infection and slower disease progression (Huang et al. 1996; Liu et al. 1996; van Rij et al. 1999). Besides CCR5, polymorphisms of other chemokine coreceptors and/or their cognate ligands have been implicated in HIV infectivity, including CCR2 (Smith et al. 1997; Kostrikis et al. 1998), CCL5 (Liu et al. 1999; McDermott et al. 2000), and CXCL12 (Winkler et al. 1998). Authoritative reviews on other gene polymorphisms that modify HIV infectivity and disease progression have been published (Lama and Planelles 2007; Singh and Spector 2009; Chatterjee 2010; Aouizerat et al. 2011).

Gene polymorphisms of opioid (OPRM1 and OPRK1) and non-opioid (e.g., $D R D 1$ and $D R D 2$ ) drug/neurotransmitter receptor genes are associated with altered HIV infectivity, viral loads and CD4+ cell counts (Proudnikov et al. 2012; Regan et al. 2012; Jacobs et al. 2013; Proudnikov et al. 2013; Dever et al. 2014). Not only do MORs mediate the behavioral consequences of opiate abuse (Bond et al. 1998; Szeto et al. 2001; Ikeda et al. 2005; Kreek et al. 2005; Xu et al. 2014b), but the ability of MOR to modulate HIV chemokine co-receptor signaling through cross desensitization or through direct molecular interactions suggest MOR may influence HIV infectivity at multiple levels. The unique ability of MOR to modulate HIV co-receptor function, prompted inquiry regarding whether variants of the OPRM1 gene (polymorphisms or splicing variants) might differentially effect HIV infectivity and/or opiate addictive behaviors. In a sample of $1031 \mathrm{HIV}$-1-infected women, 18 OPRM1 polymorphisms were significantly associated with decreases or increases in HIV infectivity and responsiveness to cART (Proudnikov et al. 2012). Other gene polymorphisms, such as enzymes affecting drug metabolism (Meyer and Zanger 1997; Benowitz et al. 2006) and other neurochemical systems (Herman and Balogh 2012; Koob and Volkow 2016) can also affect drug dependence. The A118G variant of OPRM1 alters the regulation of proinflammatory cytokine secretion (i.e., TNF- $\alpha$, IL-10, IFN- $\gamma$ ) from peripheral immune cells (Matsunaga et al. 2009). Overall, these findings suggest that polymorphisms in MOR ligands/ genes (OPRM1) can influence the pathophysiology of HIV-1.
Nineteen different $O P R M 1$ spliced variants have been described in humans (Pasternak 2004, 2014; Xu et al. 2014a; Lu et al. 2015). OPRM1 alternative splicing may also influence susceptibility to HIV-1 infection (Dever et al. 2012, 2014). Although many variants are thought to be non-functional and fail to traffic from the endoplasmic reticulum, increasing evidence suggests they may oligomerize other G Proteincoupled receptors or bind chaperones to assist in trafficking to the plasma membrane (Samoshkin et al. 2015; Zhu et al. 2019). Quantitative and qualitative differences in human MOR splice variant expression levels have been noted across different CNS cell types following exposure to HIV (Dever et al. 2012, 2014). Interestingly, an excitatory, MOR-1 K splice variant, that couples to $\mathrm{G} \alpha_{\mathrm{S}}$ (Gris et al. 2010) is preferentially expressed in human astroglia (Dever et al. 2012) and has been shown to correlate with HIVE and cognitive impairment (Dever et al. 2012, 2014).

\section{MOR and Chemokine Receptor Interactions (CCR5, CXCR4)}

The ability of opiates to modulate HIV infection and HIV neuropathogenesis/disease progression may be partly due to the interactive effects seen between the opioid and chemokine receptors, specifically MOR and CCR5 or CXCR4 (Rogers and Peterson 2003; Steele et al. 2003; Szabo et al. 2003; Festa and Meucci 2012). The potential mechanisms for this interaction can include heterologous cross-desensitization via downstream signaling (Rogers et al. 2000; Steele et al. 2002; Song et al. 2011) and/or potentially via direct opioid-chemokine receptor dimeric or heteromeric interactions (Suzuki et al. 2002; Chen et al. 2004; Nash and Meucci 2014). MOR and DOR activation can heterologously desensitize CCR5 responsiveness to CCL3, CCL4, and CCL5 in monocytes (Grimm et al. 1998; Szabo et al. 2003; Chen et al. 2004). The crossdesensitization appears to be regulated by MOR-dependent $\mathrm{PKC} \zeta$ activation and CCR5 phosphorylation and downregulation (Song et al. 2011). Alternatively, MOR-induced downregulation of CCL2 and CCL4 mRNA reciprocally upregulates the expression of their associated receptors, CCR2b, CCR3, and CCR5 (Mahajan et al. 2005). A previous study reported significant upregulation of CCR5 and CXCR4 expression in CD14 monocytes with [D-Ala ${ }^{2}, \mathrm{~N}-\mathrm{MePhe}^{4}$, Gly-ol]-enkephalin (DAMGO), a MOR ligand, exposure with enhanced replication of both X4- and R5-tropic viral strains of HIV (Steele et al. 2003). For CXCR4, bidirectional heterologous desensitization is less evident with MOR but has been reported for KOR, with $\mathrm{Ca}^{2+}$ signaling experiments suggesting that cross-desensitization occurs within seconds of KOR or CXCR4 activation in a concentration-dependent manner (Finley et al. 2008). Thus, opiates acting at different opioid receptors in the presence of HIV appear to activate chemokine receptor signaling and can contribute to the synergistic effects 


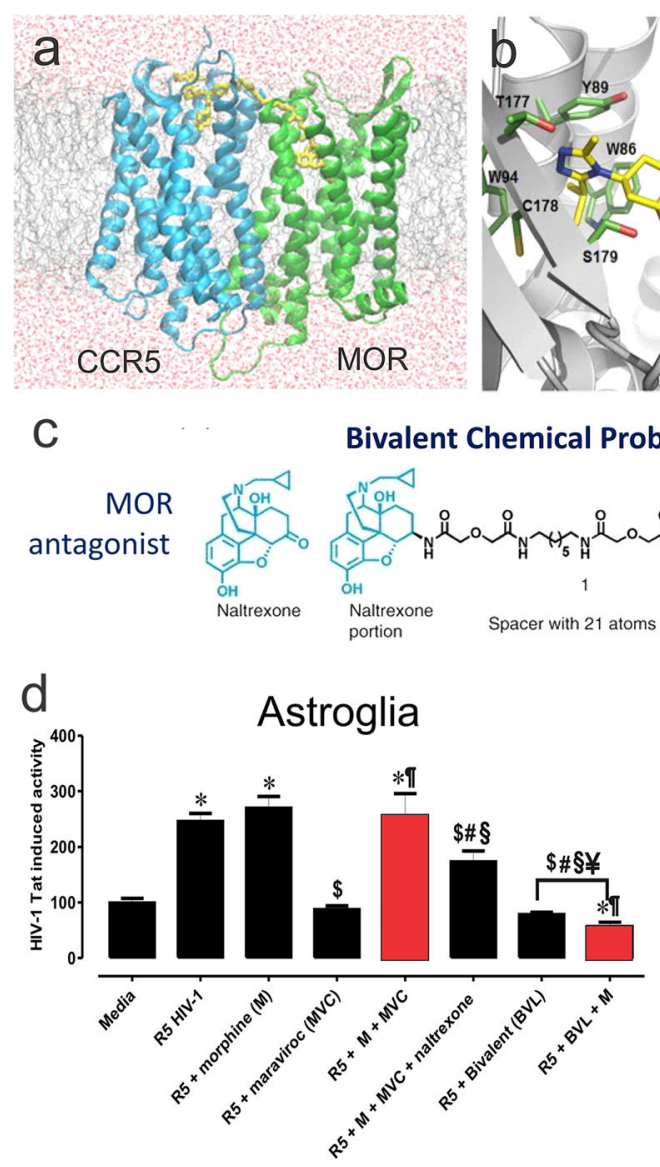

Fig. 5 Differential inhibition of HIV-1 entry into human glia by maraviroc and a bivalent CCR5-MOR antagonist (BVL) with cellspecific interactions in combination with morphine. (a) Construction of a MOR-CCR5 heterodimer model in a membrane (gray), and aqueous surrounds (red) system. The green protein represents MOR and the blue protein represents CCR5, while the bivalent ligand is colored in yellow. (b) Different binding pocket (green) for the triazole moiety of the bivalent ligand yellow) at $0 \mathrm{~ns}$ and $6.0 \mathrm{~ns}$. (c) Construction of a chemical probe that interacts with both the MOR and CCR5 receptors simultaneously. To monitor HIV-1 infection (d) astrocytes and (e) microglia were transfected with a pBlue3'LTR-luc reporter sensitive to Tat expression and luciferase activity was measured. Data indicate that maraviroc's antiviral effects are completely negated in both astrocytes and microglia when morphine is

of HIV and opioid drug co-exposure seen in neuroHIV progression.

The ability of opiates to modulate CCR5 expression in the CNS has been demonstrated to occur in various cell types, including microglia (Bokhari et al. 2009), and astrocytes (Mahajan et al. 2002). Specifically, in astrocytes MOR activation enhanced CCR5 and additional HIV-1 entry coreceptor (CCR3 and CXCR2) expression, whereas local production of HIV-1 protective chemokines (IL-8, CCL4) was inhibited (Mahajan et al. 2002). Deletion of CCR5 significantly attenuates morphine-induced increases in astrocyte CCL2 immunoreactivity in Tat transgenic mice (El-Hage et al. 2008a) (Fig. 1). Interestingly, the proportion of CCL2

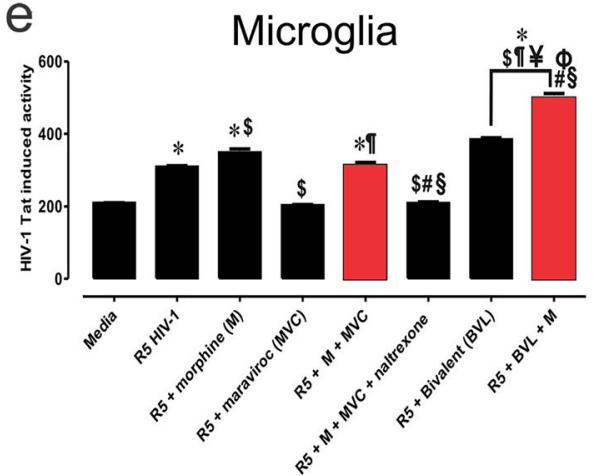

present (red bars). Interestingly, unlike maraviroc, the bivalent compound blocked HIV entry in astrocytes irrespective of morphine treatment. By contrast, the bivalent antagonist exacerbated HIV infectivity in microglia in the presence of morphine (red bars). The findings reveal fundamental differences in co-regulation of MOR and CCR5 expression in astroglia and microglia upon HIV and/or morphine exposure (see El-Hage et al. 2013). Values are luminescence intensity \pm SEM from 3 to 5 independent experiments at $18 \mathrm{~h}$ post-infection $\left({ }^{*} p<\right.$ 0.005 vs. un-infected cells; ${ }^{\$} p<0.05$ vs. R5 HIV-1; ${ }^{*} p<0.05$ vs. R5 + morphine (M); ${ }^{\text {II }} p<0.05$ vs. R5 + maraviroc (MVC); ${ }^{8} p<0.05$ vs. R5 + $\mathrm{M}+\mathrm{MVC} ;{ }^{¥} p<0.05$ vs. R5 + M + MVC + naltrexone). (a-b) Modified and reprinted with permission from Arnatt et al. (2016). (c-e) Modified and reprinted with permission from El-Hage et al. (2013)

immunoreactive macrophages/microglia in CCL5(-/-) mice after Tat and morphine co-administration still showed a significant upregulation, suggesting CCL5 regulates Tat and morphine-induced increases in CCL2 in astrocytes, but not in microglia (El-Hage et al. 2008a) (Fig. 1).

The cell type specific interactions between CCR5 and MOR were noted when using a bivalent ligand derivative of maraviroc linked to an opioid antagonist, naltrexone, with HIV-1 entry being significantly blocked in astrocytes but not microglia (El-Hage et al. 2013) (Fig. 5). Interestingly, maraviroc's antiviral effects are completely negated in both astrocytes and microglia when morphine is present suggesting that maraviroc 

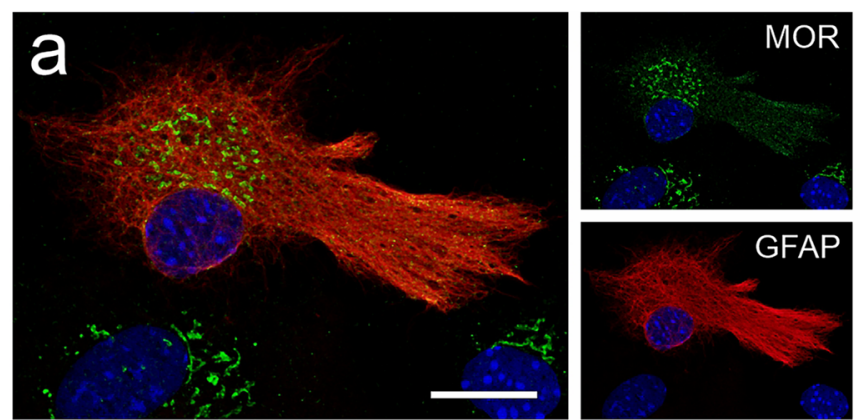

C
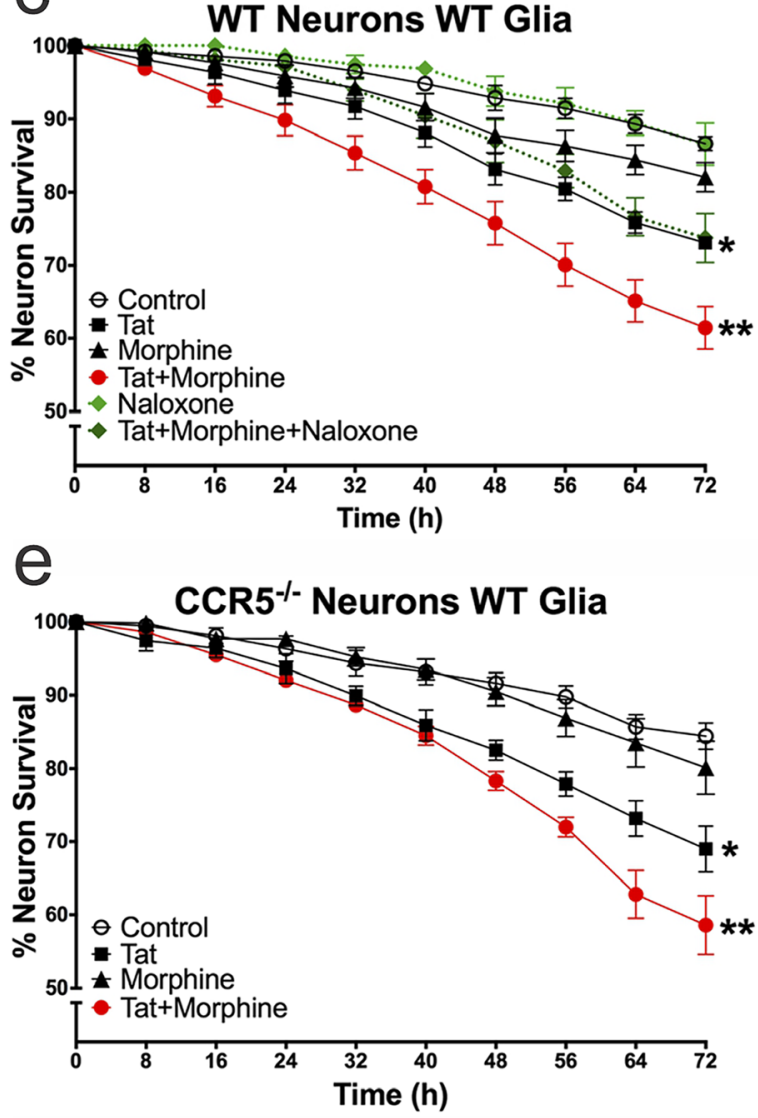

9
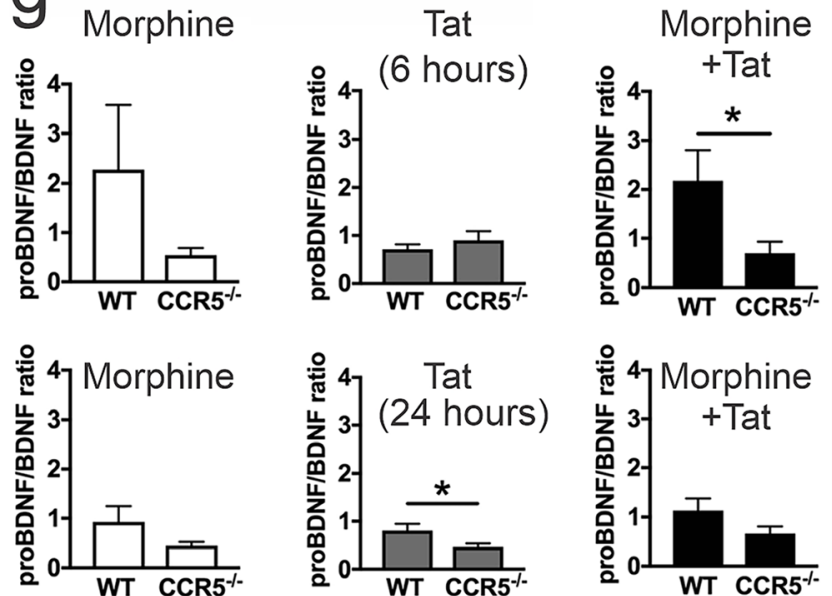
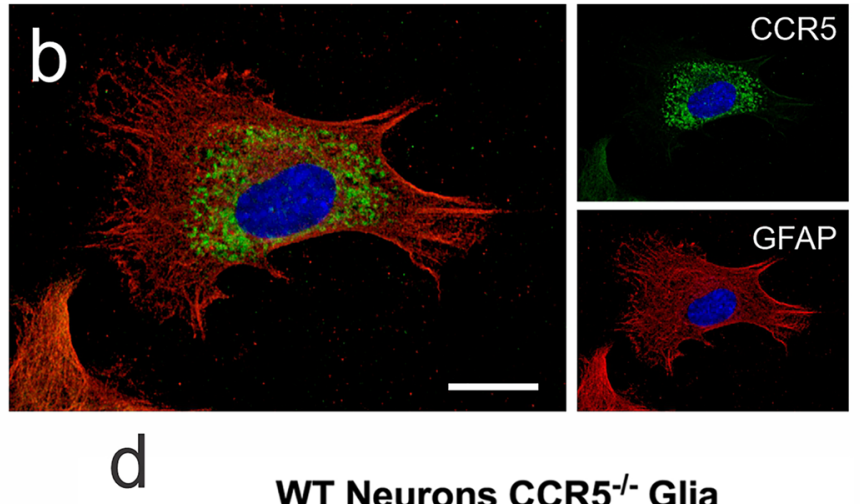

WT Neurons CCR5 ${ }^{-/-}$Glia

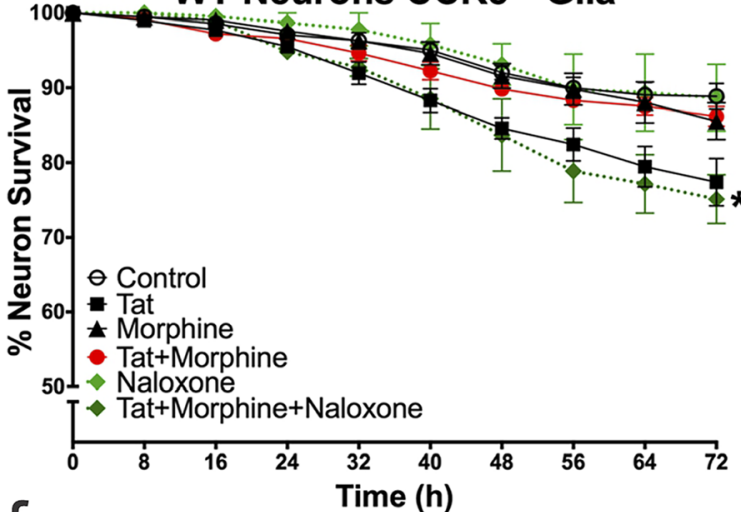

f Time (h)

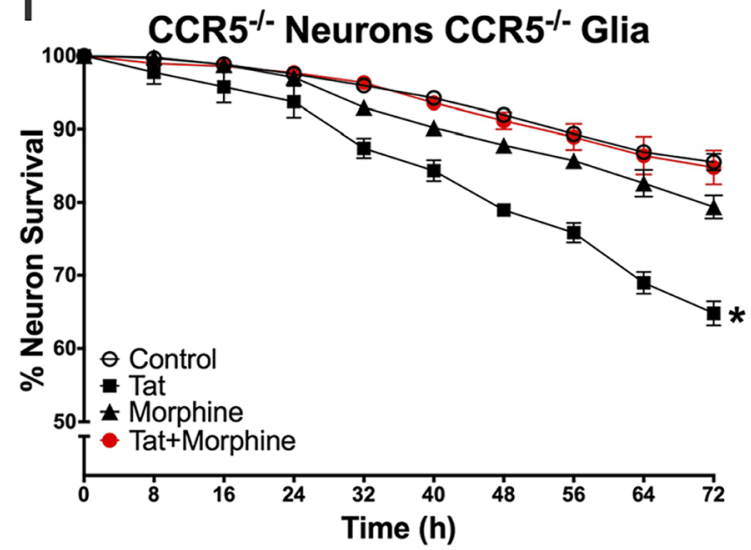

h

\section{WT Neurons WT Glia}

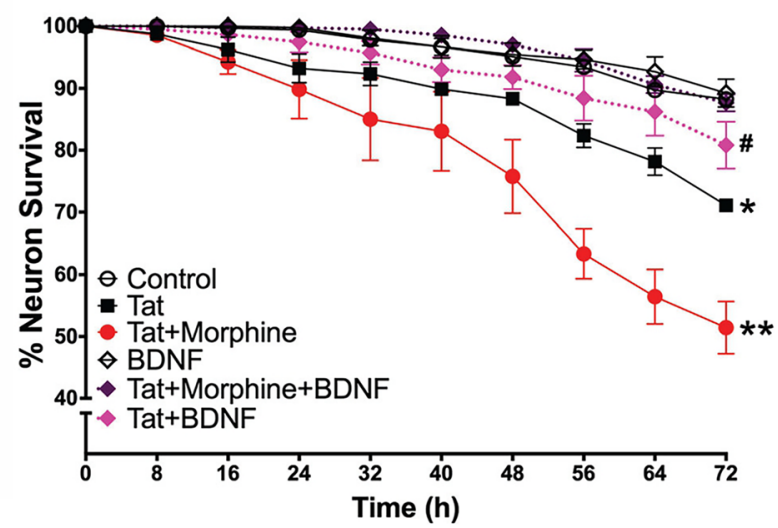


Fig. 6 Role of CCR5 and BDNF in mediating HIV-1 Tat and morphineinduced interactive cytotoxicity in striatal medium spiny neurons (MSNs). A proportion of glial fibrillary acidic protein (GFAP)immunolabeled striatal astrocytes display punctate patterns of $\mu$-opioid receptor (MOR) (a) and CCR5 (b) (43.8 $\pm 2.4 \%)$ immunofluorescencewith some faint immunoreactivity extending into the cell processes; scale bars $=10 \mu \mathrm{m}(\mathbf{a}-\mathbf{b})$. HIV-1 Tat and morphine are no longer toxic to MSNs when CCR5 is deleted from glia (c-f). In C57BL/J wild-type mixed gliaMSN co-cultures, Tat is neurotoxic ( ${ }^{*} p=0.001$ vs. controls), and coexposure to morphine enhanced Tat-induced toxicity over a 72-h period (** $p<0.001$ vs. controls, $p<0.05$ vs. Tat) and antagonized by naloxone (c). Naloxone or morphine by themselves had no effect on neuronal survival (c). In co-cultures with CCR5-deficit glia and wild-type neurons, exposure to Tat by itself is significantly toxic $\left({ }^{*} p<0.001 \mathrm{vs}\right.$. controls); however, the enhanced toxicity seen with combined morphine exposure was eliminated (d). Unexpectedly, morphine co-treatment entirely abolished the toxic effects of Tat, restoring MSN survival to control levels. Pre-treatment with naloxone re-established Tat toxicity, suggesting that the paradoxical protective effects of morphine are mediated by MOR (or perhaps another opioid receptor type) (d) (see Kim et al. 2018). The neurotoxic patterns seen in CCR5-deficient MSNs and wild-type glial co-cultures are similar to wild-type cocultures (e). Co-cultures in which MSNs and glia are both deficient in CCR5 are similar to those in which CCR5 is only deficient in glia (f). CCR5 deletion alters the expression and processing of BDNF precursor (pro-BDNF) to mature (mBDNF) by mixed-glial cultures (g). BDNF is expressed by both astroglia and microglia; mBDNF is neuroprotective, while pro-BDNF can promote programmed cell death. $\mathrm{mBDNF}$ and proBDNF levels were analyzed in conditioned media from wild-type or CCR5-deficient mixed glia treated with Tat \pm morphine after $6 \mathrm{~h}$ or $24 \mathrm{~h}$ to assess pro-BDNF and mBDNF levels. The proportion of pro$\mathrm{BDNF} / \mathrm{mBDNF}$ levels was significantly higher in wild-type compared to CCR5-null glia at $24 \mathrm{~h}$ (lower row; $\mathbf{g}$ ), suggesting reduced neuronal support. Although morphine significantly decreased pro-BDNF in CCR5-deficient glia at both $6 \mathrm{~h}$ and $24 \mathrm{~h}$ compared to control levels (not shown), the pro-BDNF/mBDNF ratios were unaltered (upper and lower rows; g). By contrast, combined Tat and morphine significantly decreased the pro-BDNF/mBDNF ratio at $6 \mathrm{~h}$, suggesting transient protection with CCR5 deficiency that was not fully sustained at $24 \mathrm{~h}$ $(p=0.17)(* p<0.05$, wild-type vs. CCR5-null) (g). Exogenous mBDNF is neuroprotective against combined Tat and morphine treatment (h). Wild-type, mixed glial-MSN co-cultures were treated with $\mathrm{mBDNF}$ and Tat, or combined Tat and morphine (represented by dotted survival curves). Tat alone was neurotoxic $(* p<0.05)$, and Tat was significantly worsened by co-exposing MSNs to morphine $(* * p<$ $0.0001)$. The addition of $\mathrm{mBDNF}(50 \mathrm{ng} / \mathrm{ml} ; 72 \mathrm{~h})$ fully protected MSNs against combined Tat and morphine toxicity, but only tended to protect (albeit not significantly) MSNs treated with Tat alone $\left(^{\#}\right)(\mathbf{h})$. Overall, the results in c-h suggest (1) an important role for glial CCR5 in mediating HIV-1 and opiate neurotoxic interactions, (2) that CCR5 deficiency influences signaling through MOR, and (3) that CCR5 (and perhaps MOR) act via a BDNF intermediary to promote or obstruct neuronal survival (Kim et al. 2018). (a-b) Modified and reprinted with permission from Podhaizer et al. (2012). (c-h) Modified and reprinted from Kim et al. (2018), which is an open access article distributed under the terms of the Creative Commons CC BY license

therapy may not be effective with opiate co-exposure. Importantly, unlike maraviroc, the bivalent compound blocked HIV entry in astrocytes irrespective of morphine treatment, while exacerbating HIV infectivity in morphine co-exposed microglia and revealing fundamental differences in the regulation of MOR and CCR5 expression in these glial types. Whereas, MOR and
CCR5 expression appear to be similarly regulated in astrocytes, their expression patterns in microglia appear to be inversely correlated upon HIV and/or morphine exposure, with CCR5 being expressed at much higher levels than MOR (see El-Hage et al. 2013). The differential effects of the bivalent ligand in astrocytes compared to microglia might be due to the fact that the expression levels of MOR and CCR5 are differentially regulated by HIV in each of the cell types (El-Hage et al. 2013; Yuan et al. 2013; Arnatt et al. 2016).

The importance of CCR5 activation in glia, but not neurons, in mediating the neurotoxic effects of morphine-dependent MOR activation is further supported in a recent study demonstrating that the loss of CCR5 from glia (but not neurons) eliminated neurotoxicity due to Tat and morphine interactions (Kim et al. 2018). Similarly, short-duration (5 d) maraviroc pretreatment also eliminated neurotoxicity and attenuated neuronal increases in $\left[\mathrm{Ca}^{2+}\right]_{\mathrm{i}}$ caused by Tat \pm morphine (Kim et al. 2018). Selectively deleting either CCR5 (Kim et al. 2018) or MOR (Zou et al. 2011) from glia completely protects MSNs from morphine's ability to exacerbate Tat neurotoxicity. However, deleting CCR5 from glia only revealed a paradoxical neuroprotective effect of morphine on Tat toxicity that is mediated by opioid receptors and appears to involve alterations in BDNF processing and signaling (Kim et al. 2018).

\section{Enhanced Mature BDNF (mBDNF) Produced by CCR5 Deficient} Glia is Neuroprotective Mature BDNF (mBDNF) activates tyrosine receptor kinase $\mathrm{B}(\mathrm{TrkB})$ and is neuroprotective, while the precursor to BDNF, pro-BDNF, binds $\mathrm{p} 75^{\mathrm{NTR}}$ and can activate cell death pathways. Based on findings of significant, reversible reductions in glially produced BDNF after exposure to $\mathrm{HIV}$-infected cell supernatant \pm morphine (Masvekar et al. 2014), altered BDNF processing in lymphocytes from PWH (Avdoshina et al. 2011), and following exposure to HIV-1 gp120 (Bachis et al. 2012), the proBDNF:mBDNF ratio was analyzed in supernatants from wild-type vs. CCR5-null striatal glial cultures exposed to Tat \pm morphine for 6 or $24 \mathrm{~h}$ (Kim et al. 2018) (Fig. 6). CCR5-deficiency reduced this ratio by over 2 -fold in cells treated with Tat and morphine after 6 h (Fig. 6), indicating a relative increase in $\mathrm{mBDNF}$ that may partially protect neurons in the CCR5-deficient glial environment.

Exogenous mBDNF treatment has been found to mimic the pro-survival effect of glial CCR5 deficiency against Tat \pm morphine, and its neuroprotective effects have been supported in other neurodegenerative disease models (Cai et al. 2014; $\mathrm{Xu}$ et al. 2018). Collectively, the findings suggest that the loss of CCR5 may fundamentally change MOR signaling in HIVexposed glia in a BDNF-dependent manner. Thus, overall the interaction of opioid and chemokine receptors, specifically 
MOR and CCR5, may alter the neuropathogenesis of HIV in a qualitatively unique manner not seen with either disorder alone.

\section{Does HIV Alter the Endogenous Opioid System?}

Little is known about the effects of HIV on the endogenous opioid system and the extent to which HIV might disrupt the expression and function of opioid peptides and receptors, and vice versa. Because opiate drugs act exclusively by mimicking endogenous peptides and engaging opioid receptors, it is likely that endogenous opioids also interact with HIV to some extent to affect the pathogenesis of neuroHIV.

The endogenous opioid system comprises three originally described opioid receptors, MOR, KOR, and DOR and endogenous opioid peptide-expressing genes proopiomelanocortin $(P O M C)$, prodynorphin $(P D Y N)$, and proenkephalin (PENK) (Brownstein 1993; Trescot et al. 2008; Bodnar 2010; Pasternak and Pan 2013), as well as a fourth receptor (OPRN1) and peptide (nociceptin/orphanin FQ) family member. The endogenous opioid system has a fundamental role in pain regulation and has been implicated in the pathophysiology of various neurologic diseases (Nandhu et al. 2010; Sauriyal et al. 2011; Benarroch 2012) and in pain management (Bruehl et al. 2013).

Postmortem clinical studies indicate the endogenous opioid system is disrupted in neuroHIV (Gelman et al. 2012; Yuferov et al. 2014). Specifically, OPRK1 mRNA is significantly upregulated in PWH (Yuferov et al. 2014) and in transgenic neuroHIV rodent models (Chang et al. 2007; Fitting et al. 2010b) potentially as a compensatory neuroprotective function in response to inflammatory processes in the presence of HIV infection (Yuferov et al. 2014). The upregulation of mRNA coding OPRK1 is triggered by factors released by activated macrophages and glia and is supported by mechanistic studies in dorsal root ganglia (Puehler et al. 2006; Gabrilovac et al. 2012). Since leukocytes, including macrophages, can express $\beta$-endorphin and enkephalins, it is important to consider the potential influence of leukocyte-derived endogenous opioid peptides in neuroinflammation (Rittner et al. 2001). Granulocytes express about 10-fold higher levels of $\beta$-endorphin, a preferential MOR and lower affinity KOR endogenous ligand, than lymphocytes (Pallinger and Csaba 2008). Increases in $\beta$-endorphin expression by peripheral blood mononuclear cells (PBMCs) (Gironi et al. 2000; Gironi et al. 2003), coincide with inflammation and relapse in multiple sclerosis. Moreover, increases in inflammatory cytokines, such as interleukin-1 $\beta$ (IL-1 $\beta$ ), have been demonstrated to differentially increase the expression of proenkephalin transcripts in primary astrocytes cultured from different brain regions (Ruzicka and Akil 1997) and increase IL-10-stimulated $\beta$-endorphin expression in cultured primary microglia (Wu et al. 2017). Interestingly, OPRM1 mRNA levels do not differ between HIV+ and HIV- subjects (Yuferov et al. 2014).

PENK was downregulated in brain samples from $446 \mathrm{PWH}$ compared to 67 HIV negative patients (Gelman et al. 2012). The subjects with HIV also expressed higher levels of interferon regulatory factor 1 (IRF1) transcripts. The idea that higher opioid peptide expression levels are neuroprotective has been supported in human studies and experimental animal models (Solbrig and Koob 2004; Sarkisyan et al. 2015; Nam et al. 2019) suggesting the reductions in PENK expression are deleterious.

The effects of HIV Tat on expression levels of opioid peptide and receptor levels depend on the individual CNS region involved as well as levels of tat transgene expression (Fitting et al. 2010b). For example, while PDYN mRNA levels were significantly reduced in the hippocampus and striatum of Tatexpressing mice, $P O M C$ was only significantly reduced by Tat induction in the striatum and PENK mRNA levels in the hippocampus were affected by chronic (but not acute) Tat exposure (Fitting et al. 2010b). Thus, HIV may alter the endogenous opioid system by modifying the expression of opioid peptides and their receptors in a brain- and cell-type specific manner. The consequences of HIV-1-dependent alterations in the endogenous opioid system to HAND are uncertain.

\section{Questions Remaining - Future Directions}

\section{Modeling the Pharmacology of Opioid Self- Administration}

Opiate self-administration as seen with addiction can have different CNS consequences than "steady-state" (e.g., continuous via a pump or time-release drug implant) exposure to the same drug (Kreek 1987, 2001; Kreek et al. 2002), and we predict the pharmacokinetic differences in opiate exposure will markedly impact neuroHIV progression. Differential effects based on "on-off" and "steady-state" drug administration schedules have been reported for the stress-responsive hypothalamic-pituitary-adrenal (HPA) axis, the endogenous opioid system, and the dopamine system (Kreek 1973; Kreek et al. 2002; George et al. 2012). Acute opiate exposure typically activates the HPA axis, corticotropin releasing factor, and peripheral steroidogenesis in a species-dependent manner (Koob and Kreek 2007; Cleck and Blendy 2008). Alternatively, chronic self-administration of short-acting opiates suppresses diurnal cortisol rhythmicity (Facchinetti et al. 1984; Vuong et al. 2010), while opiate withdrawal typically evokes HPA activation (Culpepper-Morgan and Kreek 1997; Kreek 2007; Paris et al. 2020). The daily, repeated bouts of relative withdrawal seen with opiate addiction cause sustained HPA activation, stress (Koob and Kreek 2007; Koob 2020), and immune suppression (Eisenstein 2019). Importantly, maintenance therapy with the long-acting drug methadone achieves steady-dose opiate 
levels and normalization of the HPA axis (Kreek 1973). Further, it is known that HIV infection significantly alters the HPA axis, due to CNS toxicity and cytokine production (Costa et al. 2000; George and Bhangoo 2013; Chrousos and Zapanti 2014).

Additionally, the nature of opiate exposure in the context of neuroHIV needs to be considered as it may induce different outcomes on neurotransmitter metabolism and gene expression. Specifically, the NAc shell demonstrates molecular and structural changes associated with intravenous heroin self-administration (Jacobs et al. 2005). Moreover, earlier studies have reported differential alterations in the turnover rates of various neurotransmitters for active versus passive morphine administration, including dopamine, serotonin, $\gamma$-aminobutyric acid (GABA), acetylcholine, aspartate, and glutamate during exposure to morphine (Smith et al. 1982, 1984). The disruptions were noticed specifically in brain regions involved in reinforcement processes, including the NAc, frontal cortex, and striatum, and encompassed increased dopamine and norepinephrine levels and turnover, which are central in opiate reward processes (Smith et al. 1982). Heroin abuse is known to downregulate dopaminergic activity in the NAc and may reflect a compensatory reduction in of dopamine biosynthesis in response to excessive dopaminergic stimulation resulting from chronic opiate exposure (Kish et al. 2001). Additionally, HIV is known to interfere with dopamine neurotransmission (Nath et al. 2000b; Gaskill et al. 2017) causing reductions in presynaptic dopamine terminals and dopamine transport in the striatum (Wang et al. 2004; Chang et al. 2008; Midde et al. 2012, 2015). The decline in dopamine function may exacerbate opioid abuse tendencies and drug-seeking behaviors as the rewarding effects of opioids are discounted by neuroHIV.

\section{Opioid Substitution Therapies and the Role of Selective/Biased Agonism in neuroHIV Pathogenesis}

Although morphine, methadone, and buprenorphine all activate MOR, each can impart different signals through MOR, related to the nature and timing of their coupling to $G \alpha, G \beta \gamma, \beta$-arrestin and/or regulators of $G$ protein signaling (RGS), since each downstream effector couples into unique cell functions. Functional selectivity occurs at each opioid receptor type, and for most endogenous opioid peptides at all three receptor types (Gomes et al. 2020). Moreover, opioid receptors can be expressed on a subset of virtually every cell type in the CNS - with second messenger coupling to each opioid receptor type potentially being unique, cell-type specific, and context dependent. Thus, the "pluridimensional" (Galandrin and Bouvier 2006; Kenakin 2011; Costa-Neto et al. 2016) actions of any opiate at MOR are sufficiently complicated that it is not possible to predict whether, e.g., morphine, methadone or buprenorphine, would similarly effect any aspect of neuroHIV pathology without empirical testing. Despite their significant use as medication-assisted therapies for treating opioid addiction, few studies have directly compared commonly used opiate substitution therapies (Bell and Strang 2020), especially in relation to HIV (Khalsa et al. 2006; Choi et al. 2020).

Opioid substitution therapies significantly reduce the frequency of injection drug use (Kwiatkowski and Booth 2001; Pettes et al. 2010), decrease HIV transmission risk (MacArthur et al. 2012; Platt et al. 2016), and reduce drug-related mortality (Mathers et al. 2013) and the risk of opioid overdose (Volkow et al. 2014). Further, improved ARV outcomes among PWH have been reported with opioid substitution therapies, including the uptake and retention on ARV, medication adherence rates, and viral suppression (Low et al. 2016; Mukandavire et al. 2017). The two main medications used for opioid substitution therapy include methadone, a MOR full agonist, and buprenorphine, a MOR partial agonist and partial antagonist of KOR (Noble and Marie 2018). In comparison to methadone, buprenorphine has been shown to have fewer pharmacodynamic interactions with ARVs and causes less opioid withdrawal symptoms potentially due to its partial agonism on MOR, but also due to its high affinity and long duration of MOR binding (Walsh et al. 1994; McCance-Katz 2005; Whelan and Remski 2012). Further, differential proinflammatory and neurotoxic effects have been noted for various opioid treatments (Boland et al. 2014; Fitting et al. 2014b; Carvallo et al. 2015; Dutta and Roy 2015). In primary astrocytes, agonist-selective actions at MOR and KOR can be clearly demonstrated (Bohn et al. 2000; Belcheva et al. 2003; McLennan et al. 2008; Hahn et al. 2010), and we found that morphine, methadone, and buprenorphine differentially increase ROS and $\left[\mathrm{Ca}^{2+}\right]_{\mathrm{i}}$ alone or following Tat co-exposure (Fitting et al. 2014b). Morphine can enhance HIV-1-induced production of cytokines and specifically chemokines (El-Hage et al. 2008a; Dave 2012; El-Hage et al. 2014), while other opioids including methadone, oxycodone, buprenorphine, and DAMGO can decrease inflammatory function and decrease monocyte migration (Boland et al. 2014; Carvallo et al. 2015; Jaureguiberry-Bravo et al. 2016; Chilunda et al. 2019).

As most opiate drugs preferentially act via MOR, a potential explanation for differential interactive effects of opioids in the context of neuroHIV is the phenomenon of selective or "biased agonism", such that different agonists can trigger distinct signaling events at the same receptor (Hauser et al. 2012). For example, coupling of MOR to $\mathrm{G} \alpha, \mathrm{G} \beta \gamma$, and/or $\beta$-arrestin have been noted to differ depending on the MOR agonists involved (McPherson et al. 2010; Thompson et al. 2015; Burgueno et al. 2017). Physiologic outcomes of MOR activation in any cell type are determined by a bias for specific signaling pathways, the initial step of which is activation of $G$ proteins and/or $\beta$ arrestin (Williams et al. 2013b; Violin et al. 2014; Suomivuori et al. 2020). The subcellular organization of GPCR signaling transduced by heterotrimeric $\mathrm{G}$ proteins and $\beta$-arrestin has been recently reviewed in detail (Eichel and von Zastrow 2018).

In the context of HIV, it has been shown that selective MOR agonists such as endomorphin-1, but not DAMGO or morphine, 
significantly increase HIV-1 replication in infected microglia (Peterson et al. 1999). This effect might be due to an apparent bias of endomorphin-1 towards arrestin recruitment and receptor phosphorylation, which was significantly correlated with agonist-induced internalization of MOR (McPherson et al. 2010). It is suggested that ligands that display bias towards $G$ protein-mediated pathways and away from $\beta$-arrestin 2 recruitment may have improved therapeutic profiles against the development of tolerance and dependence/addiction (McPherson et al. 2010).

\section{Opioid Effects on Antiretroviral Efficacy within the CNS and Vice Versa}

Opioid misuse has been linked to poor adherence to cART (Jeevanjee et al. 2014). However, adherence to ARV therapy improves after initiation of opioid substitution therapy (Nosyk et al. 2015; Low et al. 2016; Adams et al. 2020). Although better adherence can improve therapeutic outcomes in PWH, little information is currently available on the interaction between opioids or opioid substitution therapies and cART specifically within the CNS.

There are several known drug-drug interactions between opioids and ARVs that affect systemic concentrations. The partial opioid agonist, buprenorphine, is metabolized primarily by cytochrome P450 (CYP) 3A4 and 2C8. Both buprenorphine and its active metabolite, norbuprenorphine, are glucuronidated by UDP-glucuronosyltransferase (UGT) 1A1 and then excreted in bile. Several ARVs inhibit or induce these metabolic pathways. However, not all interactions are clinically relevant. The boosted protease inhibitor combination, atazanavir/ritonavir, inhibits CYP 3A4 and UGT 1A1, leading to increases in overall systemic exposure of buprenorphine and norbuprenorphine and also results in symptoms of opioid excess, such as increased sedation and impaired cognition (McCance-Katz et al. 2007). Dose adjustments of buprenorphine are recommended when initiating therapy with atazanavir to avoid symptoms of opioid excess. Methadone is a full opioid substrate with multiple metabolic pathways, including CYP 3A4, 2B6, 2C19, 2C9, and 2D6. Several pharmacokinetic interactions are reported between methadone and protease inhibitors. However, withdrawal symptoms are rare, and therefore, dose adjustments are not recommended (Bruce et al. 2006; Meemken et al. 2015). In contrast, efavirenz and nevirapine induce CYP 3A4, resulting in decreased systemic concentrations of methadone and the development of opioid withdrawal symptoms. To avoid opioid withdrawal, increased methadone dosing is recommended when either efavirenz or nevirapine therapy is initiated (Marzolini et al. 2000; Clarke et al. 2001; Meemken et al. 2015). Oxycodone metabolism is inhibited by lopinavir/ritonavir, increasing oxycodone concentrations as well as the self-reported drug effects (Nieminen et al. 2010; Feng et al. 2017).
The pharmacokinetic studies above focused on overall systemic exposure of drugs. Plasma concentrations, however, are not always accurate indicators of tissue exposure. Similarly, CNS drug exposure is often estimated based on drug concentrations within the CSF. However, CSF drug levels may not accurately predict brain concentrations. For many drugs with high efflux activities (e.g., substrates of P-gp), CSF tends to overpredict brain tissue concentrations (Liu et al. 2006; Friden et al. 2009; Kodaira et al. 2011, 2014). This could be due, in part, to differential expression of transporters at the blood-CSF barrier vs. BBB. In a study of the ARV drug amprenavir, concentrations of $\left[{ }^{14} \mathrm{C}\right]$-amprenavir in CSF versus brain were $23.3 \pm 11.2$ and $3.33 \pm 0.6 \mathrm{nCi} / \mathrm{g}$, respectively, demonstrating overprediction of brain concentrations by CSF (Polli et al. 1999). These studies illustrate the high likelihood of misinterpreting drug brain penetration when using CSF as the surrogate marker. Therefore, direct measurement of brain tissue concentrations in animal models are likely to be more predictive of the interactive effects of ARVs and opioids on ARV and/or opioid brain exposure.

A few studies have investigated the impact of opioids and ARV administration on drug concentrations within the brain. One study investigated the impact of $5 \mathrm{~d}$ continuous exposure to morphine on ARV brain concentrations (dolutegravir, lamivudine and abacavir) and demonstrated that morphine exposure resulted in regionally specific decreases in the concentrations of select ARV drugs (Leibrand et al. 2019) and, furthermore, that the decreases in ARV concentrations (dolutegravir and abacavir) were likely due to increased efflux by the drug efflux transport protein, P-gp (Leibrand et al. 2019). Morphine alterations in P-gp within the brain could have wide reaching impact on other CNS active drugs.

HIV preferentially infects microglia and perivascular macrophages within the brain, although BMECs, astrocytes, and pericytes can also be infected (Kramer-Hammerle et al. 2005). Achieving optimal intracellular ARV concentrations are essential to suppress the infection. Few studies have examined whether ARV drugs differentially accumulate within different neural cell types and especially within cells of the neurovascular unit. Although nucleoside reverse transcriptase inhibitors (NRTIs) and non-nucleoside reverse transcriptase inhibitors (NNRTIs) are efficacious in inhibiting viral replication within monocyte-derived macrophages, only a few drugs within each ARV class can effectively inhibit viral replication within astrocytes (Gray et al. 2013), which could be a result of poor intracellular accumulation within astrocytes. In vitro studies have demonstrated darunavir and raltegravir intracellular concentrations to be approximately 100-fold lower (with higher $\mathrm{EC}_{50}$ values) in microglia than in PBMCs (Asahchop et al. 2017).

Another study measured intracellular concentrations of dolutegravir, tenofovir and emtricitabine in primary human astrocytes, microglia, pericytes and BMECs (Patel et al. 2019). Intracellular ARV concentrations were typically significantly higher in BMECs than in the other brain cell types. 
Dolutegravir achieved the highest relative concentrations within each cell type, whereas tenofovir accumulated the least (Patel et al. 2019). Furthermore, $24 \mathrm{~h}$ treatment with morphine significantly decreased intracellular accumulation of composite ARV concentrations, but only in astrocytes. In contrast, morphine exposure significantly increased the net accumulation of drugs within BMECs compared to controls. BMECs may sequester ARV drugs as a protective mechanism (Patel et al. 2019).

Using experimental data from SIV-infected, morphineaddicted macaques, mathematical modeling suggests that morphine exposure increases the proportion of cells with high susceptibility to SIV infection, at least in part, because of increased co-receptor expression (Vaidya et al. 2016). In addition to promoting a higher steady state viral loads and larger CD4 count declines, the model also predicts that morphine exposure results in the need for more efficacious ARV treatment than would be necessary for animals not exposed to morphine (Vaidya et al. 2016). Although the direct impact of morphine on ARV concentrations was not investigated, the study provides evidence supporting morphine's negative impact on ARV efficacy.

Acknowledgements Portions of this review were initially presented at the Satellite Symposium of the 25th SNIP Scientific Conference entitled, "Unraveling NeuroAIDS in the Presence of Substance Use Disorder" that was sponsored and organized by NIH/NIDA. Co-Chairs: Yu (Woody) Lin and Roger Sorensen (April 10, 2019)

Funding This work was supported by the National Institute on Drug Abuse: R01 DA034231 (KFH), R01 DA044855 (KFH), R01 DA045588 (KFH), R01 DA018633 (KFH), R21 DA045630 (MM), and R01 DA045596 (SF).

\section{Compliance with Ethical Standards}

Conflict of Interest The authors declare that they have no conflict of interest.

Open Access This article is licensed under a Creative Commons Attribution 4.0 International License, which permits use, sharing, adaptation, distribution and reproduction in any medium or format, as long as you give appropriate credit to the original author(s) and the source, provide a link to the Creative Commons licence, and indicate if changes were made. The images or other third party material in this article are included in the article's Creative Commons licence, unless indicated otherwise in a credit line to the material. If material is not included in the article's Creative Commons licence and your intended use is not permitted by statutory regulation or exceeds the permitted use, you will need to obtain permission directly from the copyright holder. To view a copy of this licence, visit http://creativecommons.org/licenses/by/4.0/.

\section{References}

Adams JW, Marshall BDL, Mohd Salleh NA, Barrios R, Nolan S, Milloy MJ (2020) Receipt of opioid agonist treatment halves the risk of HIV-1 RNA viral load rebound through improved ART adherence for HIV-infected women who use illicit drugs. Drug Alcohol Depend 206:107670
Adler MW, Geller EB, Rogers TJ, Henderson EE, Eisenstein TK (1993) Opioids, receptors, and immunity. Adv Exp Med Biol 335:13-20

Alaee A, Zarghami M, Farnia S, Khademloo M, Khoddad T (2014) Comparison of brain white matter hyperintensities in methamphetamine and methadone dependent patients and healthy controls. Iran J Radiol 11:e14275

Albright AV, Strizki J, Harouse JM, Lavi E, O'Connor M, GonzalezScarano F (1996) HIV-1 infection of cultured human adult oligodendrocytes. Virology 217:211-219

Alexander GC, Stoller KB, Haffajee RL, Saloner B (2020) An epidemic in the midst of a pandemic: opioid use disorder and COVID-19. Ann Intern Med 173:57-58

Al-Harthi L, Joseph J, Nath A (2019) Correction to: astrocytes as an HIV CNS reservoir: highlights and reflections of an NIMH-sponsored symposium. J Neurovirol 25:616

Al-Hasani R, Bruchas MR (2011) Molecular mechanisms of opioid receptor-dependent signaling and behavior. Anesthesiology 115: $1363-1381$

Alvarez-Carbonell D, Garcia-Mesa Y, Milne S, Das B, Dobrowolski C, Rojas R, Karn J (2017) Toll-like receptor 3 activation selectively reverses HIV latency in microglial cells. Retrovirology 14:9

Alvarez-Carbonell D, Ye F, Ramanath N, Garcia-Mesa Y, Knapp PE, Hauser KF, Karn J (2019) Cross-talk between microglia and neurons regulates HIV latency. PLoS Pathog 15:e1008249

Andras IE, Pu H, Deli MA, Nath A, Hennig B, Toborek M (2003) HIV-1 Tat protein alters tight junction protein expression and distribution in cultured brain endothelial cells. J Neurosci Res 74:255-265

Anthony IC, Ramage SN, Carnie FW, Simmonds P, Bell JE (2005) Does drug abuse alter microglial phenotype and cell turnover in the context of advancing HIV infection? Neuropathol Appl Neurobiol 31: 325-338

Anthony IC, Arango JC, Stephens B, Simmonds P, Bell JE (2008) The effects of illicit drugs on the HIV infected brain. Front Biosci 13: 1294-1307

Anthony IC, Norrby KE, Dingwall T, Carnie FW, Millar T, Arango JC, Robertson R, Bell JE (2010) Predisposition to accelerated Alzheimer-related changes in the brains of human immunodeficiency virus negative opiate abusers. Brain 133:3685-3698

Aouizerat BE, Pearce CL, Miaskowski C (2011) The search for host genetic factors of HIV/AIDS pathogenesis in the post-genome era: progress to date and new avenues for discovery. Curr HIV/AIDS Rep 8:38-44

Applebaum AJ, Reilly LC, Gonzalez JS, Richardson MA, Leveroni CL, Safren SA (2009) The impact of neuropsychological functioning on adherence to HAART in HIV-infected substance abuse patients. AIDS Patient Care STDs 23:455-462

Applebaum AJ, Otto MW, Richardson MA, Safren SA (2010) Contributors to neuropsychological impairment in HIV-infected and HIV-uninfected opiate-dependent patients. J Clin Exp Neuropsychol 32:579-589

Aquilante CL, Letrent SP, Pollack GM, Brouwer KL (2000) Increased brain P-glycoprotein in morphine tolerant rats. Life Sci 66:PL47PL51

Arnatt CK, Falls BA, Yuan Y, Raborg TJ, Masvekar RR, El-Hage N, Selley DE, Nicola AV, Knapp PE, Hauser KF, Zhang Y (2016) Exploration of bivalent ligands targeting putative mu opioid receptor and chemokine receptor CCR5 dimerization. Bioorg Med Chem 24: 5969-5987

Asahchop EL, Meziane O, Mamik MK, Chan WF, Branton WG, Resch L, Gill MJ, Haddad E, Guimond JV, Wainberg MA, Baker GB, Cohen EA, Power C (2017) Reduced antiretroviral drug efficacy and concentration in HIV-infected microglia contributes to viral persistence in brain. Retrovirology 14:47 
Atwood WJ, Tornatore CS, Meyers K, Major EO (1993) HIV-1 mRNA transcripts from persistently infected human fetal astrocytes. Ann N Y Acad Sci 693:324-325

Avdoshina V, Biggio F, Palchik G, Campbell LA, Mocchetti I (2010) Morphine induces the release of CCL5 from astrocytes: potential neuroprotective mechanism against the HIV protein gp120. Glia 58:1630-1639

Avdoshina V, Garzino-Demo A, Bachis A, Monaco MC, Maki PM, Tractenberg RE, Liu C, Young MA, Mocchetti I (2011) HIV-1 decreases the levels of neurotrophins in human lymphocytes. AIDS 25:1126-1128

Baba M, Oishi R, Saeki K (1988) Enhancement of blood-brain barrier permeability to sodium fluorescein by stimulation of mu opioid receptors in mice. Naunyn Schmiedeberg's Arch Pharmacol 337: 423-428

Bachis A, Avdoshina V, Zecca L, Parsadanian M, Mocchetti I (2012) Human immunodeficiency virus type 1 alters brain-derived neurotrophic factor processing in neurons. J Neurosci 32:9477-9484

Balinang JM, Masvekar RR, Hauser KF, Knapp PE (2017) Productive infection of human neural progenitor cells by R5 tropic HIV-1: opiate co-exposure heightens infectivity and functional vulnerability. AIDS 31:753-764

Bandaru VV, Patel N, Ewaleifoh O, Haughey NJ (2011) A failure to normalize biochemical and metabolic insults during morphine withdrawal disrupts synaptic repair in mice transgenic for HIV-gp120. J NeuroImmune Pharmacol 6:640-649

Banerjee A, Zhang X, Manda KR, Banks WA, Ercal N (2010) HIV proteins (gp120 and Tat) and methamphetamine in oxidative stress-induced damage in the brain: potential role of the thiol antioxidant $\mathrm{N}$-acetylcysteine amide. Free Radic Biol Med 48:13881398

Banerjee A, Strazza M, Wigdahl B, Pirrone V, Meucci O, Nonnemacher MR (2011) Role of mu-opioids as cofactors in human immunodeficiency virus type 1 disease progression and neuropathogenesis. J Neurovirol 17:291-302

Barat C, Proust A, Deshiere A, Leboeuf M, Drouin J, Tremblay MJ (2018) Astrocytes sustain long-term productive HIV-1 infection without establishment of reactivable viral latency. Glia 66:13631381

Barbour AJ, Hauser KF, McQuiston AR, Knapp PE (2020) HIV and opiates dysregulate $\mathrm{K}^{+}-\mathrm{Cl}$ cotransporter $2(\mathrm{KCC} 2)$ to cause GABAergic dysfunction in primary human neurons and Tat-transgenic mice. Neurobiol Dis 141: 104878

Bauer LO (1998) Effects of chronic opioid dependence and HIV-1 infection on pattern shift visual evoked potentials. Drug Alcohol Depend 50:147-155

Becker WC, Fiellin DA (2020) When epidemics collide: coronavirus disease 2019 (COVID-19) and the opioid crisis. Ann Intern Med 173: 59-60

Bednar MM, Sturdevant CB, Tompkins LA, Arrildt KT, Dukhovlinova E, Kincer LP, Swanstrom R (2015) Compartmentalization, viral evolution, and viral latency of HIV in the CNS. Curr HIV/AIDS Rep 12:262-271

Belcheva MM, Tan Y, Heaton VM, Clark AL, Coscia CJ (2003) $\mu-$ Opioid transactivation and down-regulation of the epidermal growth factor receptor in astrocytes: implications for mitogen-activated protein kinase signaling. Mol Pharmacol 64:1391-1401

Bell J, Strang J (2020) Medication treatment of opioid use disorder. Biol Psychiatry $87: 82-88$

Bell JE, Brettle RP, Chiswick A, Simmonds P (1998) HIV encephalitis, proviral load and dementia in drug users and homosexuals with AIDS. Effect of neocortical involvement. Brain 121(Pt 11):20432052
Bell JE, Arango JC, Robertson R, Brettle RP, Leen C, Simmonds P (2002) HIV and drug misuse in the Edinburgh cohort. J Acquir Immune Defic Syndr 31(Suppl 2):S35-S42

Bell JE, Arango JC, Anthony IC (2006) Neurobiology of multiple insults: HIV-1-associated brain disorders in those who use illicit drugs. J NeuroImmune Pharmacol 1:182-191

Benarroch EE (2012) Endogenous opioid systems: current concepts and clinical correlations. Neurology 79:807-814

Benowitz NL, Swan GE, Jacob P 3rd, Lessov-Schlaggar CN, Tyndale RF (2006) CYP2A6 genotype and the metabolism and disposition kinetics of nicotine. Clin Pharmacol Ther 80:457-467

Berger AC, Whistler JL (2010) How to design an opioid drug that causes reduced tolerance and dependence. Ann Neurol 67:559-569

Berman JW et al (2006) NeuroAIDS, drug abuse, and inflammation: building collaborative research activities. J NeuroImmune Pharmacol 1:351-399

Bernardo A, Agresti C, Levi G (1997) HIV-gp120 affects the functional activity of oligodendrocytes and their susceptibility to complement. J Neurosci Res 50:946-957

Blankson JN, Persaud D, Siliciano RF (2002) The challenge of viral reservoirs in HIV-1 infection. Annu Rev Med 53:557-593

Bodnar RJ (2010) Endogenous opiates and behavior: 2009. Peptides 31: 2325-2359

Bohn LM, Belcheva MM, Coscia CJ (2000) $\mu$-Opioid agonist inhibition of $\mathrm{K}$-opioid receptor-stimulated extracellular signal-regulated kinase phosphorylation is dynamin-dependent in C6 glioma cells. J Neurochem 74:574-581

Boivin MJ, Ruel TD, Boal HE, Bangirana P, Cao H, Eller LA, Charlebois E, Havlir DV, Kamya MR, Achan J, Akello C, Wong JK (2010) HIV-subtype A is associated with poorer neuropsychological performance compared with subtype $\mathrm{D}$ in antiretroviral therapy-naive Ugandan children. AIDS 24:1163-1170

Bokhari SM, Yao H, Bethel-Brown C, Fuwang P, Williams R, Dhillon NK, Hegde R, Kumar A, Buch SJ (2009) Morphine enhances tatinduced activation in murine microglia. J Neurovirol 15:219-228

Bokhari SM, Hegde R, Callen S, Yao H, Adany I, Li Q, Li Z, Pinson D, Yeh HW, Cheney PD, Buch S (2011) Morphine potentiates neuropathogenesis of SIV infection in rhesus macaques. J NeuroImmune Pharmacol 6:626-639

Boland JW, Foulds GA, Ahmedzai SH, Pockley AG (2014) A preliminary evaluation of the effects of opioids on innate and adaptive human in vitro immune function. BMJ Support Palliat Care 4: $357-367$

Bond C, LaForge KS, Tian M, Melia D, Zhang S, Borg L, Gong J, Schluger J, Strong JA, Leal SM, Tischfield JA, Kreek MJ, Yu L (1998) Single-nucleotide polymorphism in the human mu opioid receptor gene alters $\beta$-endorphin binding and activity: possible implications for opiate addiction. Proc Natl Acad Sci USA 95:96089613

Bora E, Yucel M, Fornito A, Pantelis C, Harrison BJ, Cocchi L, Pell G, Lubman DI (2012) White matter microstructure in opiate addiction. Addict Biol 17:141-148

Boska MD, Dash PK, Knibbe J, Epstein AA, Akhter SP, Fields N, High R, Makarov E, Bonasera S, Gelbard HA, Poluektova LY, Gendelman HE, Gorantla S (2014) Associations between brain microstructures, metabolites, and cognitive deficits during chronic HIV-1 infection of humanized mice. Mol Neurodegener 9:58

Bourne RS, Mills GH (2004) Sleep disruption in critically ill patientspharmacological considerations. Anaesthesia 59:374-384

Boven LA, Middel J, Verhoef J, De Groot CJ, Nottet HS (2000) Monocyte infiltration is highly associated with loss of the tight junction protein zonula occludens in HIV-1-associated dementia. Neuropathol Appl Neurobiol 26:356-360 
Browne CJ, Godino A, Salery M, Nestler EJ (2020) Epigenetic mechanisms of opioid addiction. Biol Psychiatry 87:22-33

Brownstein MJ (1993) A brief history of opiates, opioid peptides, and opioid receptors. Proc Natl Acad Sci U S A 90:5391-5393

Bruce RD, McCance-Katz E, Kharasch ED, Moody DE, Morse GD (2006) Pharmacokinetic interactions between buprenorphine and antiretroviral medications. Clin Infect Dis 43(Suppl 4):S216-S223

Bruehl S, Apkarian AV, Ballantyne JC, Berger A, Borsook D, Chen WG, Farrar JT, Haythornthwaite JA, Horn SD, Iadarola MJ, Inturrisi CE, Lao L, Mackey S, Mao J, Sawczuk A, Uhl GR, Witter J, Woolf CJ, Zubieta JK, Lin Y (2013) Personalized medicine and opioid analgesic prescribing for chronic pain: opportunities and challenges. The journal of pain : official journal of the American Pain Society 14: $103-113$

Bruner KM et al (2019) A quantitative approach for measuring the reservoir of latent HIV-1 proviruses. Nature 566:120-125

Buch SK, Khurdayan VK, Lutz SE, Knapp PE, El-Hage N, Hauser KF (2007) Glial-restricted precursors: patterns of expression of opioid receptors and relationship to human immunodeficiency virus-1 Tat and morphine susceptibility in vitro. Neuroscience 146:1546-1554

Burdo TH, Lackner A, Williams KC (2013) Monocyte/macrophages and their role in HIV neuropathogenesis. Immunol Rev 254:102-113

Burgueno J, Pujol M, Monroy X, Roche D, Varela MJ, Merlos M, Giraldo J (2017) A complementary scale of biased agonism for agonists with differing maximal responses. Sci Rep 7:15389

Buttner A (2011) Review: the neuropathology of drug abuse. Neuropathol Appl Neurobiol 37:118-134

Buttner A, Weis S (2006) Neuropathological alterations in drug abusers : the involvement of neurons, glial, and vascular systems. Forensic Sci Med Pathol 2:115-126

Buttner A, Rohrmoser K, Mall G, Penning R, Weis S (2006) Widespread axonal damage in the brain of drug abusers as evidenced by accumulation of $\beta$-amyloid precursor protein ( $\beta$-APP): an immunohistochemical investigation. Addiction 101:1339-1346

Byrd DA, Fellows RP, Morgello S, Franklin D, Heaton RK, Deutsch R, Atkinson JH, Clifford DB, Collier AC, Marra CM, Gelman B, McCutchan JA, Duarte NA, Simpson DM, McArthur J, Grant I (2011) Neurocognitive impact of substance use in HIV infection. J Acquir Immune Defic Syndr 58:154-162

Byrd D, Murray J, Safdieh G, Morgello S (2012) Impact of opiate addiction on neuroinflammation in HIV. J Neurovirol 18:364-373

Cadet JL, Bisagno V, Milroy CM (2014) Neuropathology of substance use disorders. Acta Neuropathol 127:91-107

Cai J, Hua F, Yuan L, Tang W, Lu J, Yu S, Wang X, Hu Y (2014) Potential therapeutic effects of neurotrophins for acute and chronic neurological diseases. Biomed Res Int 2014:601084

Campbell GR, Watkins JD, Loret EP, Spector SA (2011) Differential induction of rat neuronal excitotoxic cell death by human immunodeficiency virus type 1 clade B and C Tat proteins. AIDS Res Hum Retrovir 27:647-654

Canto-Nogues C, Sanchez-Ramon S, Alvarez S, Lacruz C, MunozFernandez MA (2005) HIV-1 infection of neurons might account for progressive HIV-1-associated encephalopathy in children. J Mol Neurosci 27:79-89

Caputi FF, Rullo L, Stamatakos S, Candeletti S, Romualdi P (2019) Interplay between the endogenous opioid system and proteasome complex: beyond signaling. International Journal of Molecular Sciences 20: 1441

Carr DJJ, Serou M (1995) Exogenous and endogenous opioids as biological response modifiers. Immunopharmacology 31:59-71

Carr DJ, Rogers TJ, Weber RJ (1996) The relevance of opioids and opioid receptors on immunocompetence and immune homeostasis. Proc Soc Exp Biol Med 213:248-257
Carvallo L, Lopez L, Che FY, Lim J, Eugenin EA, Williams DW, Nieves E, Calderon TM, Madrid-Aliste C, Fiser A, Weiss L, Angeletti RH, Berman JW (2015) Buprenorphine decreases the CCL2-mediated chemotactic response of monocytes. J Immunol 194:3246-3258

CDC (2017) Understanding the epidemic. Centers for Disease Control and Prevention, National Center for Injury Prevention and Control, Division of Unintentional Injury Prevention https://www.cdc.gov/ drugoverdose/epidemic/index.html

Chang SL, Beltran JA, Swarup S (2007) Expression of the mu opioid receptor in the human immunodeficiency virus type 1 transgenic rat model. J Virol 81:8406-8411

Chang L, Wang GJ, Volkow ND, Ernst T, Telang F, Logan J, Fowler JS (2008) Decreased brain dopamine transporters are related to cognitive deficits in HIV patients with or without cocaine abuse. NeuroImage 42:869-878

Chao CC, Gekker G, Sheng WS, Hu S, Portoghese PS, Peterson PK (1995) Endogenous opioid peptides suppress cytokine-mediated upregulation of HIV-1 expression in the chronically infected promonocyte clone U1. Adv Exp Med Biol 373:65-72

Chao CC, Hu S, Peterson PK (1996a) Opiates, glia, and neurotoxicity. Adv Exp Med Biol 402:29-33

Chao CC, Gekker G, Hu S, Sheng WS, Shark KB, Bu DF, Archer S, Bidlack JM, Peterson PK (1996b) K opioid receptors in human microglia downregulate human immunodeficiency virus 1 expression. Proc Natl Acad Sci U S A 93:8051-8056

Chao CC, Gekker G, Hu S, Kravitz F, Peterson PK (1998a) k-Opioid potentiation of tumor necrosis factor- $\alpha$-induced anti-HIV-1 activity in acutely infected human brain cell cultures. Biochem Pharmacol 56:397-404

Chao CC, Gekker G, Sheng WS, Hu S, Loh HH, Peterson PK (1998b) Orphan opioid receptor oligonucleotides inhibit HIV-1 expression in human brain cells. Adv Exp Med Biol 437:83-90

Chao CC, Hu S, Gekker G, Lokensgard JR, Heyes MP, Peterson PK (2000) U50,488 protection against HIV-1-related neurotoxicity: involvement of quinolinic acid suppression. Neuropharmacology 39 : $150-160$

Chao J, Yang L, Yao H, Buch S (2014) Platelet-derived growth factor-BB restores HIV Tat-mediated impairment of neurogenesis: role of GSK-3 $\beta / \beta$-catenin. J NeuroImmune Pharmacol 9:259-268

Chatterjee K (2010) Host genetic factors in susceptibility to HIV-1 infection and progression to AIDS. J Genet 89:109-116

Chaves C, Gomez-Zepeda D, Auvity S, Menet MC, Crete D, Labat L, Remiao F, Cisternino S, Decleves X (2016) Effect of subchronic intravenous morphine infusion and naloxone-precipitated morphine withdrawal on P-gp and Bcrp at the rat blood-brain barrier. J Pharm Sci 105:350-358

Chen C, Li J, Bot G, Szabo I, Rogers TJ, Liu-Chen LY (2004) Heterodimerization and cross-desensitization between the $\mu$-opioid receptor and the chemokine CCR5 receptor. Eur J Pharmacol 483: 175-186

Chen Y, An H, Zhu H, Stone T, Smith JK, Hall C, Bullitt E, Shen D, Lin W (2009) White matter abnormalities revealed by diffusion tensor imaging in non-demented and demented HIV+ patients. NeuroImage 47:1154-1162

Chen K, Phan T, Lin A, Sardo L, Mele AR, Nonnemacher MR, Klase Z (2020) Morphine exposure exacerbates HIV-1 Tat driven changes to neuroinflammatory factors in cultured astrocytes. PLoS One 15: e 0230563

Chilunda V, Calderon TM, Martinez-Aguado P, Berman JW (2019) The impact of substance abuse on HIV-mediated neuropathogenesis in the current ART era. Brain Res 1724:146426

Choi S, Yerneni R, Healy S, Goyal M, Neighbors CJ (2020) Predictors of medication utilization for opioid use disorder among medicaid- 
insured HIV patients in New York. The American journal on addictions / American Academy of Psychiatrists in Alcoholism and Addictions 29:151-154

Chrousos GP, Zapanti ED (2014) Hypothalamic-pituitary-adrenal axis in HIV infection and disease. Endocrinol Metab Clin N Am 43: 791-806

Churchill MJ, Gorry PR, Cowley D, Lal L, Sonza S, Purcell DF, Thompson KA, Gabuzda D, McArthur JC, Pardo CA, Wesselingh SL (2006) Use of laser capture microdissection to detect integrated HIV-1 DNA in macrophages and astrocytes from autopsy brain tissues. J Neuro-Oncol 12:146-152

Churchill MJ, Wesselingh SL, Cowley D, Pardo CA, McArthur JC, Brew BJ, Gorry PR (2009) Extensive astrocyte infection is prominent in human immunodeficiency virus-associated dementia. Ann Neurol 66:253-258

Churchill MJ, Deeks SG, Margolis DM, Siliciano RF, Swanstrom R (2016) HIV reservoirs: what, where and how to target them. Nat Rev Microbiol 14:55-60

Clarke SM, Mulcahy FM, Tjia J, Reynolds HE, Gibbons SE, Barry MG, Back DJ (2001) The pharmacokinetics of methadone in HIVpositive patients receiving the non-nucleoside reverse transcriptase inhibitor efavirenz. Br J Clin Pharmacol 51:213-217

Cleck JN, Blendy JA (2008) Making a bad thing worse: adverse effects of stress on drug addiction. J Clin Invest 118:454-461

Cloak CC, Chang L, O'Neil SP, Ernst TM, Anderson DC, Donahoe RM (2011) Neurometabolite abnormalities in simian immunodeficiency virus-infected macaques with chronic morphine administration. J NeuroImmune Pharmacol 6:371-380

Coller JK, Hutchinson MR (2012) Implications of central immune signaling caused by drugs of abuse: mechanisms, mediators and new therapeutic approaches for prediction and treatment of drug dependence. Pharmacol Ther 134:219-245

Collett BJ (1998) Opioid tolerance: the clinical perspective. Br J Anaesth 81:58-68

Concha M, Selnes OA, Vlahov D, Nance-Sproson T, Updike M, Royal W, Palenicek J, McArthur JC (1997) Comparison of neuropsychological performance between AIDS-free injecting drug users and homosexual men. Neuroepidemiology 16:78-85

Correa DG, Zimmermann N, Doring TM, Wilner NV, Leite SC, Cabral RF, Fonseca RP, Bahia PR, Gasparetto EL (2015) Diffusion tensor MR imaging of white matter integrity in HIV-positive patients with planning deficit. Neuroradiology 57:475-482

Costa A, Nappi RE, Polatti F, Poma A, Grossman AB, Nappi G (2000) Stimulating effect of HIV-1 coat protein gp120 on corticotropinreleasing hormone and arginine vasopressin in the rat hypothalamus: involvement of nitric oxide. Exp Neurol 166:376-384

Costa-Neto CM, Parreiras ESLT, Bouvier M (2016) A pluridimensional view of biased Agonism. Mol Pharmacol 90:587-595

Crystal HA, Hamon S, Randesi M, Cook J, Anastos K, Lazar J, Liu C, Pearce L, Golub E, Valcour V, Weber KM, Holman S, Ho A, Kreek MJ (2012) A C17T polymorphism in the mu opiate receptor is associated with quantitative measures of drug use in African American women. Addict Biol 17:181-191

Culpepper-Morgan JA, Kreek MJ (1997) Hypothalamic-pituitary-adrenal axis hypersensitivity to naloxone in opioid dependence: a case of naloxone-induced withdrawal. Metab Clin Exp 46:130-134

Dallasta LM, Pisarov LA, Esplen JE, Werley JV, Moses AV, Nelson JA, Achim CL (1999) Blood-brain barrier tight junction disruption in human immunodeficiency virus-1 encephalitis. Am J Pathol 155: $1915-1927$

Danos P, Van Roos D, Kasper S, Bromel T, Broich K, Krappel C, Solymosi L, Moller HJ (1998) Enlarged cerebrospinal fluid spaces in opiate-dependent male patients: a stereological CT study. Neuropsychobiology 38:80-83

Dave RS (2012) Morphine affects HIV-induced inflammatory response without influencing viral replication in human monocyte-derived macrophages. FEMS Immunol Med Microbiol 64:228-236

Del Valle L, Croul S, Morgello S, Amini S, Rappaport J, Khalili K (2000) Detection of HIV-1 Tat and JCV capsid protein, VP1, in AIDS brain with progressive multifocal leukoencephalopathy. J Neurovirol 6: 221-228

Denis CM, Morales KH, Wu Q, Metzger DS, Cheatle MD (2019) Association between diagnoses of chronic noncancer pain, substance use disorder, and HIV-related outcomes in people living with HIV. J Acquir Immune Defic Syndr 82(Suppl 2):S142-S147

Dever SM, Xu R, Fitting S, Knapp PE, Hauser KF (2012) Differential expression and HIV-1 regulation of $\mu$-opioid receptor splice variants across human central nervous system cell types. J Neurovirol 18: $181-190$

Dever SM, Costin BN, Xu R, El-Hage N, Balinang J, Samoshkin A, O'Brien MA, McRae M, Diatchenko L, Knapp PE, Hauser KF (2014) Differential expression of the alternatively spliced OPRMI isoform $\mu$-opioid receptor- $1 \mathrm{~K}$ in $\mathrm{HIV}$-infected individuals. AIDS 28:19-30

Do T, Murphy G, Earl LA, Del Prete GQ, Grandinetti G, Li GH, Estes JD, Rao P, Trubey CM, Thomas J, Spector J, Bliss D, Nath A, Lifson JD, Subramaniam S (2014) Three-dimensional imaging of HIV-1 virological synapses reveals membrane architectures involved in virus transmission. J Virol 88:10327-10339

Donahoe RM, Falek A (1988) Neuroimmunomodulation by opiates and other drugs of abuse: relationship to HIV infection and AIDS. Adv Biochem Psychopharmacol 44:145-158

Donahoe RM, Vlahov D (1998) Opiates as potential cofactors in progression of HIV-1 infections to AIDS. J Neuroimmunol 83:77-87

Donahoe RM, Falek A, Madden JJ, Nicholson JK, Bokos P, Gallegos K, Veit R (1991) Effects of cocaine and other drugs of abuse on immune function. Adv Exp Med Biol 288:143-150

Dronda F, Zamora J, Moreno S, Moreno A, Casado JL, Muriel A, PerezElias MJ, Antela A, Moreno L, Quereda C (2004) CD4 cell recovery during successful antiretroviral therapy in naive HIV-infected patients: the role of intravenous drug use. AIDS 18:2210-2212

Dublin S, Walker RL, Gray SL, Hubbard RA, Anderson ML, Yu O, Crane PK, Larson EB (2015) Prescription opioids and risk of dementia or cognitive decline: a prospective cohort study. J Am Geriatr Soc 63:1519-1526

Duncan MJ, Bruce-Keller AJ, Conner C, Knapp PE, Xu R, Nath A, Hauser KF (2008) Effects of chronic expression of the HIVinduced protein, transactivator of transcription, on circadian activity rhythms in mice, with or without morphine. Am J Physiol Regul Integr Comp Physiol 295:R1680-R1687

Dutta R, Roy S (2012) Mechanism(s) involved in opioid drug abuse modulation of HAND. Curr HIV Res 10:469-477

Dutta R, Roy S (2015) Chronic morphine and HIV-1 Tat promote differential central nervous system trafficking of CD3+ and Ly6C+ immune cells in a murine Streptococcus pneumoniae infection model. J Neuroinflammation 12:120

Dutta R, Krishnan A, Meng J, Das S, Ma J, Banerjee S, Wang J, Charboneau R, Prakash O, Barke RA, Roy S (2012) Morphine modulation of toll-like receptors in microglial cells potentiates neuropathogenesis in a HIV-1 model of coinfection with pneumococcal pneumoniae. J Neurosci 32:9917-9930

Dyuizen I, Lamash NE (2009) Histo- and immunocytochemical detection of inducible NOS and TNF- $\alpha$ in the locus coeruleus of human opiate addicts. J Chem Neuroanat 37:65-70 
Eap CB, Buclin T, Baumann P (2002) Interindividual variability of the clinical pharmacokinetics of methadone: implications for the treatment of opioid dependence. Clin Pharmacokinet 41:1153-1193

Eichel K, von Zastrow M (2018) Subcellular organization of GPCR signaling. Trends Pharmacol Sci 39:200-208

Eisenstein TK (2019) The role of opioid receptors in immune system function. Front Immunol 10:2904

El-Hage N, Gurwell JA, Singh IN, Knapp PE, Nath A, Hauser KF (2005) Synergistic increases in intracellular $\mathrm{Ca}^{2+}$, and the release of MCP1, RANTES, and IL- 6 by astrocytes treated with opiates and HIV-1 Tat. Glia 50:91-106

El-Hage N, Wu G, Ambati J, Bruce-Keller AJ, Knapp PE, Hauser KF (2006a) CCR2 mediates increases in glial activation caused by exposure to HIV-1 Tat and opiates. J Neuroimmunol 178:9-16

El-Hage N, Wu G, Wang J, Ambati J, Knapp PE, Reed JL, Bruce-Keller AJ, Hauser KF (2006b) HIV-1 Tat and opiate-induced changes in astrocytes promote chemotaxis of microglia through the expression of MCP-1 and alternative chemokines. Glia 53:132-146

El-Hage N, Bruce-Keller AJ, Knapp PE, Hauser KF (2008a) CCL5/ RANTES gene deletion attenuates opioid-induced increases in glial CCL2/MCP-1 immunoreactivity and activation in HIV-1 Tat-exposed mice. J NeuroImmune Pharmacol 3:275-285

El-Hage N, Bruce-Keller AJ, Yakovleva T, Bazov I, Bakalkin G, Knapp PE, Hauser KF (2008b) Morphine exacerbates HIV-1 Tat-induced cytokine production in astrocytes through convergent effects on $\left[\mathrm{Ca}^{2+}\right]$, NF-kB trafficking and transcription. PLoS One 3:e4093

El-Hage N, Podhaizer EM, Sturgill J, Hauser KF (2011a) Toll-like receptor expression and activation in astroglia: differential regulation by HIV-1 Tat, gp120, and morphine. Immunol Investig 40:498-522

El-Hage N, Dever SM, Fitting S, Ahmed T, Hauser KF (2011b) HIV-1 coinfection and morphine coexposure severely dysregulate hepatitis $\mathrm{C}$ virus-induced hepatic proinflammatory cytokine release and free radical production: increased pathogenesis coincides with uncoordinated host defenses. J Virol 85:11601-11614

El-Hage N, Dever SM, Podhaizer EM, Arnatt CK, Zhang Y, Hauser KF (2013) A novel bivalent HIV-1 entry inhibitor reveals fundamental differences in CCR5- $\mu$-opioid receptor interactions between human astroglia and microglia. AIDS 27:2181-2190

El-Hage N, Rodriguez M, Podhaizer EM, Zou S, Dever SM, Snider SE, Knapp PE, Beardsley PM, Hauser KF (2014) Ibudilast (AV411), and its AV1013 analog, reduce HIV-1 replication and neuronal death induced by HIV-1 and morphine. AIDS 28:1409-1419

Elkader A, Sproule B (2005) Buprenorphine: clinical pharmacokinetics in the treatment of opioid dependence. Clin Pharmacokinet 44: $661-680$

Ensoli F, Ensoli B, Thiele CJ (1994) HIV-1 gene expression and replication in neuronal and glial cell lines with immature phenotype: effects of nerve growth factor. Virology 200:668-676

Eran A, Barak M (2009) Posterior reversible encephalopathy syndrome after combined general and spinal anesthesia with intrathecal morphine. Anesth Analg 108:609-612

Eriksson PS, Hansson E, Ronnback L (1992) Delta and kappa opiate receptors in primary astroglial cultures. Part II: receptor sets in cultures from various brain regions and interactions with beta-receptor activated cyclic AMP. Neurochem Res 17:545-551

Ersche KD, Clark L, London M, Robbins TW, Sahakian BJ (2006) Profile of executive and memory function associated with amphetamine and opiate dependence. Neuropsychopharmacology 31: 1036-1047

Ersek M, Cherrier MM, Overman SS, Irving GA (2004) The cognitive effects of opioids. Pain Manag Nurs 5:75-93

Esiri MM, Morris CS, Millard PR (1991) Fate of oligodendrocytes in HIV-1 infection. AIDS 5:1081-1088
Eugenin EA, Clements JE, Zink MC, Berman JW (2011) Human immunodeficiency virus infection of human astrocytes disrupts bloodbrain barrier integrity by a gap junction-dependent mechanism. J Neurosci 31:9456-9465

Evaluation - Institute for Health Metrics and Evaluation (2017) Global burden of disease study. Global Health Data Exchange. http://www. healthdata.org/gbd/gbd-2017-resources.

Facchinetti F, Grasso A, Petraglia F, Parrini D, Volpe A, Genazzani AR (1984) Impaired circadian rhythmicity of beta-lipotrophin, betaendorphin and ACTH in heroin addicts. Acta Endocrinol 105: $149-155$

Falek A, Donahoe RM, Madden JJ, Shafer DA (1991) Opiates as immunosuppressive and genotoxic agents. Drugs of Abuse, Immunity, and Immunodeficiency 288:189-201

Fan Y, Gao X, Chen J, Liu Y, He JJ (2016) HIV tat impairs neurogenesis through functioning as a notch ligand and activation of notch signaling pathway. J Neurosci 36:11362-11373

Fan R, Schrott LM, Arnold T, Snelling S, Rao M, Graham D, Cornelius A, Korneeva NL (2018) Chronic oxycodone induces axonal degeneration in rat brain. BMC Neurosci 19:15

Fauci AS, Redfield RR, Sigounas G, Weahkee MD, Giroir BP (2019) Ending the HIV epidemic: a plan for the United States. JAMA 321: 844-845

Feng XQ, Zhu LL, Zhou Q (2017) Opioid analgesics-related pharmacokinetic drug interactions: from the perspectives of evidence based on randomized controlled trials and clinical risk management. J Pain Res 10:1225-1239

Ferrell D, Giunta B (2014) The impact of HIV-1 on neurogenesis: implications for HAND. Cellular and molecular life sciences : CMLS 71: 4387-4392

Festa L, Meucci O (2012) Effects of opiates and HIV proteins on neurons: the role of ferritin heavy chain and a potential for synergism. Curr HIV Res 10:453-462

Festa L, Roth LM, B KJ, Geiger JD, Jordan-Sciutto KL, Grinspan JB (2019) Protease inhibitors, saquinavir and darunavir, inhibit oligodendrocyte maturation: Implications for Lysosomal Stress. J Neuroimmune Pharmacol. https://doi.org/10.1007/s11481-01909893-8.

Finley MJ, Chen X, Bardi G, Davey P, Geller EB, Zhang L, Adler MW, Rogers TJ (2008) Bi-directional heterologous desensitization between the major HIV-1 co-receptor CXCR4 and the K-opioid receptor. J Neuroimmunol 197:114-123

Fischer-Smith T, Croul S, Sverstiuk AE, Capini C, L'Heureux D, Regulier EG, Richardson MW, Amini S, Morgello S, Khalili K, Rappaport J (2001) CNS invasion by CD14+/CD16+ peripheral blood-derived monocytes in HIV dementia: perivascular accumulation and reservoir of HIV infection. J Neurovirol 7:528-541

Fitting S, Zou S, Chen W, Vo P, Hauser KF, Knapp PE (2010a) Regional heterogeneity and diversity in cytokine and chemokine production by astroglia: differential responses to HIV-1 Tat, gp120, and morphine revealed by multiplex analysis. J Proteome Res 9:1795-1804

Fitting S, Xu R, Bull C, Buch SK, El-Hage N, Nath A, Knapp PE, Hauser KF (2010b) Interactive comorbidity between opioid drug abuse and HIV-1 Tat: chronic exposure augments spine loss and sublethal dendritic pathology in striatal neurons. Am J Pathol 177:1397-1410

Fitting S, Scoggins KL, Xu R, Dever SM, Knapp PE, Dewey WL, Hauser KF (2012) Morphine efficacy is altered in conditional HIV-1 Tat transgenic mice. Eur J Pharmacol 689:96-103

Fitting S, Knapp PE, Zou S, Marks WD, Bowers MS, Akbarali HI, Hauser KF (2014a) Interactive HIV-1 Tat and morphine-induced synaptodendritic injury is triggered through focal disruptions in $\mathrm{Na}^{+}$influx, mitochondrial instability, and $\mathrm{Ca}^{2+}$ overload. $\mathrm{J}$ Neurosci 34:12850-12864 
Fitting S, Zou S, El-Hage N, Suzuki M, Paris JJ, Schier CJ, Rodriguez JW, Rodriguez M, Knapp PE, Hauser KF (2014b) Opiate addiction therapies and HIV-1 Tat: interactive effects on glial $\left[\mathrm{Ca}^{2+}\right]_{\mathrm{i}}$ oxyradical and neuroinflammatory chemokine production and correlative neurotoxicity. Curr HIV Res 12:424-434

Fitting S, Stevens DL, Khan FA, Scoggins KL, Enga RM, Beardsley PM, Knapp PE, Dewey WL, Hauser KF (2016) Morphine tolerance and physical dependence are altered in conditional HIV-1 Tat transgenic mice. J Pharmacol Exp Ther 356:96-105

Friden M, Winiwarter S, Jerndal G, Bengtsson O, Wan H, Bredberg U, Hammarlund-Udenaes M, Antonsson M (2009) Structure-brain exposure relationships in rat and human using a novel data set of unbound drug concentrations in brain interstitial and cerebrospinal fluids. J Med Chem 52:6233-6243

Fukagawa H, Koyama T, Kakuyama M, Fukuda K (2013) Microglial activation involved in morphine tolerance is not mediated by tolllike receptor 4. J Anesth 27:93-97

Gabrilovac J, Cupic B, Zapletal E, Brozovic A (2012) IFN- $\gamma$ up-regulates $\mathrm{K}$ opioid receptors (KOR) on murine macrophage cell line J774. J Neuroimmunol 245:56-65

Galandrin S, Bouvier M (2006) Distinct signaling profiles of $\beta 1$ and $\beta 2$ adrenergic receptor ligands toward adenylyl cyclase and mitogenactivated protein kinase reveals the pluridimensionality of efficacy. Mol Pharmacol 70:1575-1584

Galligan JJ (2015) HIV, opiates, and enteric neuron dysfunction. Neurogastroenterology and motility : the official journal of the European Gastrointestinal Motility Society 27:449-454

Gandhi N, Saiyed Z, Thangavel S, Rodriguez J, Rao KV, Nair MP (2009) Differential effects of HIV type 1 clade B and clade C Tat protein on expression of proinflammatory and antiinflammatory cytokines by primary monocytes. AIDS Res Hum Retrovir 25:691-699

Gaskill PJ, Miller DR, Gamble-George J, Yano H, Khoshbouei H (2017) HIV, Tat and dopamine transmission. Neurobiol Dis 105:51-73

Gandhi N, Saiyed ZM, Napuri J, Samikkannu T, Reddy PVB, Agudelo M, Khatavkar P, Saxena SK, Nair MPN (2010) Interactive role of human immunodeficiency virus type 1 (HIV-1) clade-specific Tat protein and cocaine in blood-brain barrier dysfunction: Implications for HIV-1-associated neurocognitive disorder. J Neurovirol 16(4): 294-305

Gekker G, Hu S, Wentland MP, Bidlack JM, Lokensgard JR, Peterson PK (2004) Kappa-opioid receptor ligands inhibit cocaine-induced HIV-1 expression in microglial cells. J Pharmacol Exp Ther 309: 600-606

Gelman BB, Lisinicchia JG, Chen T, Johnson KM, Jennings K, Freeman DH Jr, Soukup VM (2012) Prefrontal dopaminergic and enkephalinergic synaptic accommodation in HIV-associated neurocognitive disorders and encephalitis. J NeuroImmune Pharmacol 7:686-700

George MM, Bhangoo A (2013) Human immune deficiency virus (HIV) infection and the hypothalamic pituitary adrenal axis. Rev Endocr Metab Disord 14:105-112

George O, Le Moal M, Koob GF (2012) Allostasis and addiction: role of the dopamine and corticotropin-releasing factor systems. Physiol Behav 106:58-64

Geretti AM (2006) HIV-1 subtypes: epidemiology and significance for HIV management. Curr Opin Infect Dis 19:1-7

Ginsberg MD, Hedley-Whyte ET, Richardson EP Jr (1976) Hypoxicischemic leukoencephalopathy in man. Arch Neurol 33:5-14

Gironi M, Martinelli V, Brambilla E, Furlan R, Panerai AE, Comi G, Sacerdote $\mathrm{P}$ (2000) $\beta$-endorphin concentrations in peripheral blood mononuclear cells of patients with multiple sclerosis: effects of treatment with interferon beta. Arch Neurol 57:1178-1181
Gironi M, Furlan R, Rovaris M, Comi G, Filippi M, Panerai AE, Sacerdote $P(2003) \beta$ endorphin concentrations in PBMC of patients with different clinical phenotypes of multiple sclerosis. J Neurol Neurosurg Psychiatry 74:495-497

Gnanakaran S, Lang D, Daniels M, Bhattacharya T, Derdeyn CA, Korber B (2007) Clade-specific differences between human immunodeficiency virus type 1 clades $\mathrm{B}$ and $\mathrm{C}$ : diversity and correlations in C3V4 regions of gp120. J Virol 81:4886-4891

Gomes I, Sierra S, Lueptow L, Gupta A, Gouty S, Margolis EB, Cox BM, Devi LA (2020) Biased signaling by endogenous opioid peptides. Proc Natl Acad Sci USA 117:11820-11828

Gonek M, McLane VD, Stevens DL, Lippold K, Akbarali HI, Knapp PE, Dewey WL, Hauser KF, Paris JJ (2018) CCR5 mediates HIV-1 Tatinduced neuroinflammation and influences morphine tolerance, dependence, and reward. Brain Behav Immun 69:124-138

Gorry PR, Ong C, Thorpe J, Bannwarth S, Thompson KA, Gatignol A, Vesselingh SL, Purcell DF (2003) Astrocyte infection by HIV-1: mechanisms of restricted virus replication, and role in the pathogenesis of HIV-1-associated dementia. Curr HIV Res 1:463-473

Gosztonyi G, Schmidt V, Nickel R, Rothschild MA, Camacho S, Siegel G, Zill E, Pauli G, Schneider V (1993) Neuropathologic analysis of postmortal brain samples of HIV-seropositive and -seronegative i.v. drug addicts. Forensic Sci Int 62:101-105

Gosztonyi G, Artigas J, Lamperth L, Webster HD (1994) Human immunodeficiency virus (HIV) distribution in HIV encephalitis: study of 19 cases with combined use of in situ hybridization and immunocytochemistry. J Neuropathol Exp Neurol 53:521-534

Gray F, Scaravilli F, Everall I, Chretien F, An S, Boche D, Adle-Biassette H, Wingertsmann L, Durigon M, Hurtrel B, Chiodi F, Bell J, Lantos P (1996) Neuropathology of early HIV-1 infection. Brain Pathol 6: $1-15$

Gray LR, Tachedjian G, Ellett AM, Roche MJ, Cheng WJ, Guillemin GJ, Brew BJ, Turville SG, Wesselingh SL, Gorry PR, Churchill MJ (2013) The NRTIs lamivudine, stavudine and zidovudine have reduced HIV-1 inhibitory activity in astrocytes. PLoS One 8:e62196

Grimm MC, Ben-Baruch A, Taub DD, Howard OM, Resau JH, Wang JM, Ali H, Richardson R, Snyderman R, Oppenheim JJ (1998) Opiates transdeactivate chemokine receptors: delta and mu opiate receptor-mediated heterologous desensitization. J Exp Med 188: $317-325$

Gris P, Gauthier J, Cheng P, Gibson DG, Gris D, Laur O, Pierson J, Wentworth S, Nackley AG, Maixner W, Diatchenko L (2010) A novel alternatively spliced isoform of the mu-opioid receptor: functional antagonism. Mol Pain 6:33

Gruber SA, Silveri MM, Yurgelun-Todd DA (2007) Neuropsychological consequences of opiate use. Neuropsychol Rev 17:299-315

Guo C-J, Li Y, Tian S, Wang X, Douglas SD, Ho W-Z (2002) Morphine enhances HIV infection of human blood mononuclear phagocytes through modulation of $\beta$-chemokines and CCR 5 receptor. J Investig Med 50:435-442

Guo M, Bryant J, Sultana S, Jones O, Royal W 3rd (2012) Effects of vitamin a deficiency and opioids on parvalbumin + interneurons in the hippocampus of the HIV-1 transgenic rat. Curr HIV Res 10: 463-468

Gupta JD, Satishchandra P, Gopukumar K, Wilkie F, Waldrop-Valverde D, Ellis R, Ownby R, Subbakrishna DK, Desai A, Kamat A, Ravi V, Rao BS, Satish KS, Kumar M (2007) Neuropsychological deficits in human immunodeficiency virus type 1 clade $\mathrm{C}$-seropositive adults from South India. J Neurovirol 13:195-202

Gupta S, Knight AG, Gupta S, Knapp PE, Hauser KF, Keller JN, BruceKeller AJ (2010) HIV-Tat elicits microglial glutamate release: role of NAPDH oxidase and the cystine-glutamate antiporter. Neurosci Lett 485:233-236 
Gurwell JA, Duncan MJ, Maderspach K, Stiene-Martin A, Elde RP, Hauser KF (1996) K-opioid receptor expression defines a phenotypically distinct subpopulation of astroglia: relationship to $\mathrm{Ca}^{2+}$ mobilization, development, and the antiproliferative effect of opioids. Brain Res 737:175-187

Gurwell JA, Nath A, Sun Q, Zhang J, Martin KM, Chen Y, Hauser KF (2001) Synergistic neurotoxicity of opioids and human immunodeficiency virus- 1 Tat protein in striatal neurons in vitro. Neuroscience 102(3):555-563

Hahn JW, Jagwani S, Kim E, Rendell VR, He J, Ezerskiy LA, Wesselschmidt R, Coscia CJ, Belcheva MM (2010) Mu and kappa opioids modulate mouse embryonic stem cell-derived neural progenitor differentiation via MAP kinases. J Neurochem 112:14311441

Hahn YK, Podhaizer EM, Hauser KF, Knapp PE (2012) HIV-1 alters neural and glial progenitor cell dynamics in the central nervous system: coordinated response to opiates during maturation. Glia 60:1871-1887

Hahn YK, Paris JJ, Lichtman AH, Hauser KF, Sim-Selley LJ, Selley DE, Knapp PE (2016) Central HIV-1 Tat exposure elevates anxiety and fear conditioned responses of male mice concurrent with altered $\mu$ opioid receptor-mediated G-protein activation and $\beta$-arrestin 2 activity in the forebrain. Neurobiol Dis 92(PtB):124-136

Hauser KF, Knapp PE (2014) Interactions of HIV and drugs of abuse: the importance of glia, neural progenitors, and host genetic factors. Int Rev Neurobiol 118:231-313

Hauser KF, Knapp PE (2018) Opiate drugs with abuse liability hijack the endogenous opioid system to disrupt neuronal and glial maturation in the central nervous system. Front Pediatr 5:294

Hauser KF, Osborne JG, Stiene-Martin A, Melner MH (1990) Cellular localization of proenkephalin mRNA and enkephalin peptide products in cultured astrocytes. Brain Res 522:347-353

Hauser KF, Gurwell JA, Bhat NR (1993) Endogenous opioid systems and the growth of oligodendrocyte progenitors: paradoxical increases in oligodendrogenesis as an indirect mechanism of opioid action. Glia 9:157-162

Hauser KF, Stiene-Martin A, Mattson MP, Elde RP, Ryan SE, Godleske $\mathrm{CC}$ (1996) $\mu$-Opioid receptor-induced $\mathrm{Ca}^{2+}$ mobilization and astroglial development: morphine inhibits DNA synthesis and stimulates cellular hypertrophy through a $\mathrm{Ca}^{2+}$-dependent mechanism. Brain Res 720:191-203

Hauser KF, El-Hage N, Buch S, Berger JR, Tyor WR, Nath A, BruceKeller AJ, Knapp PE (2005) Molecular targets of opiate drug abuse in neuroAIDS. Neurotox Res 8:63-80

Hauser KF, El-Hage N, Stiene-Martin A, Maragos WF, Nath A, Persidsky Y, Volsky DJ, Knapp PE (2007) HIV-1 neuropathogenesis: glial mechanisms revealed through substance abuse. J Neurochem 100:567-586

Hauser KF, Hahn YK, Adjan VV, Zou S, Buch SK, Nath A, BruceKeller AJ, Knapp PE (2009) HIV-1 tat and morphine have interactive effects on oligodendrocyte survival and morphology. Glia 57:194-206

Hauser KF, Fitting S, Dever SM, Podhaizer EM, Knapp PE (2012) Opiate drug use and the pathophysiology of neuroAIDS. Curr HIV Res 10: 435-452

Herman AI, Balogh KN (2012) Polymorphisms of the serotonin transporter and receptor genes: susceptibility to substance abuse. Subst Abus Rehabil 3:49-57

Ho WZ, Guo CJ, Yuan CS, Douglas SD, Moss J (2003) Methylnaltrexone antagonizes opioid-mediated enhancement of HIV infection of human blood mononuclear phagocytes. J Pharmacol Exp Ther 307:1158-1162
Hu S, Sheng WS, Rock RB (2011) Immunomodulatory properties of kappa opioids and synthetic cannabinoids in HIV-1 neuropathogenesis. J NeuroImmune Pharmacol 6:528-539

$\mathrm{Hu}$ G, Yao H, Chaudhuri AD, Duan M, Yelamanchili SV, Wen H, Cheney PD, Fox HS, Buch S (2012) Exosome-mediated shuttling of microRNA-29 regulates HIV Tat and morphine-mediated neuronal dysfunction. Cell Death Dis 3:e381

Huang Y, Paxton WA, Wolinsky SM, Neumann AU, Zhang L, He T, Kang S, Ceradini D, Jin Z, Yazdanbakhsh K, Kunstman K, Erickson D, Dragon E, Landau NR, Phair J, Ho DD, Koup RA (1996) The role of a mutant CCR5 allele in HIV-1 transmission and disease progression. Nat Med 2:1240-1243

Hutchinson MR, Northcutt AL, Chao LW, Kearney JJ, Zhang Y, Berkelhammer DL, Loram LC, Rozeske RR, Bland ST, Maier SF, Gleeson TT, Watkins LR (2008) Minocycline suppresses morphineinduced respiratory depression, suppresses morphine-induced reward, and enhances systemic morphine-induced analgesia. Brain Behav Immun 22:1248-1256

Hutchinson MR, Lewis SS, Coats BD, Skyba DA, Crysdale NY, Berkelhammer DL, Brzeski A, Northcutt A, Vietz CM, Judd CM, Maier SF, Watkins LR, Johnson KW (2009) Reduction of opioid withdrawal and potentiation of acute opioid analgesia by systemic AV411 (ibudilast). Brain Behav Immun 23:240-250

Hutchinson MR et al (2010) Evidence that opioids may have toll-like receptor 4 and MD-2 effects. Brain Behav Immun 24:83-95

Hutchinson MR et al (2012) Opioid activation of toll-like receptor 4 contributes to drug reinforcement. J Neurosci 32:11187-11200

Ikeda K, Ide S, Han W, Hayashida M, Uhl GR, Sora I (2005) How individual sensitivity to opiates can be predicted by gene analyses. Trends Pharmacol Sci 26:311-317

Indelicato RA, Portenoy RK (2002) Opioid rotation in the management of refractory cancer pain. Journal of clinical oncology : official journal of the American Society of Clinical Oncology 20:348-352

Ivers JH, Fitzgerald J, Whelan C, Sweeney B, Keenan E, Fagan A, McMarrow J, Meany J, Barry J, Frodl T (2018) Progressive white matter impairment as a predictor of outcome in a cohort of opioiddependent patient's post-detoxification. Addict Biol 23:304-312

Jacobs EH, Smit AB, de Vries TJ, Schoffelmeer AN (2005) Long-term gene expression in the nucleus accumbens following heroin administration is subregion-specific and depends on the nature of drug administration. Addict Biol 10:91-100

Jacobs MM, Murray J, Byrd DA, Hurd YL, Morgello S (2013) HIVrelated cognitive impairment shows bi-directional association with dopamine receptor DRD1 and DRD2 polymorphisms in substancedependent and substance-independent populations. J Neurovirol 19: 495-504

Jankovic BD, Horvat J, Djordjijevic D, Ramah A, Fridman V, Spahic O (1991) Brain-associated autoimmune features in heroin addicts: correlation to HIV infection and dementia. The International journal of neuroscience 58:113-126

Jaureguiberry-Bravo M, Wilson R, Carvallo L, Berman JW (2016) Opioids and opioid maintenance therapies: their impact on monocyte-mediated HIV Neuropathogenesis. Curr HIV Res 14: 417-430

Jeevanjee S, Penko J, Guzman D, Miaskowski C, Bangsberg DR, Kushel MB (2014) Opioid analgesic misuse is associated with incomplete antiretroviral adherence in a cohort of HIV-infected indigent adults in San Francisco. AIDS Behav 18:1352-1358

Jensen BK, Monnerie H, Mannell MV, Gannon PJ, Espinoza CA, Erickson MA, Bruce-Keller AJ, Gelman BB, Briand LA, Pierce RC, Jordan-Sciutto KL, Grinspan JB (2015) Altered oligodendrocyte maturation and myelin maintenance: the role of Antiretrovirals 
in HIV-associated neurocognitive disorders. J Neuropathol Exp Neurol 74:1093-1118

Jensen BK, Roth LM, Grinspan JB, Jordan-Sciutto KL (2019) White matter loss and oligodendrocyte dysfunction in HIV: a consequence of the infection, the antiretroviral therapy or both? Brain Res 1724: 146397

Kang W, Hebert JM (2011) Signaling pathways in reactive astrocytes, a genetic perspective. Mol Neurobiol 43:147-154

Kenakin T (2011) Functional selectivity and biased receptor signaling. J Pharmacol Exp Ther 336:296-302

Khalsa J, Vocci F, Altice F, Fiellin D, Miller V (2006) Buprenorphine and HIV primary care: new opportunities for integrated treatment. Clin Infect Dis 43(Suppl 4):S169-S172

Kharasch ED (2017) Current concepts in methadone metabolism and transport. Clin Pharmacol Drug Dev 6:125-134

Khatri UG, Perrone J (2020) Opioid use disorder and COVID-19: crashing of the crises. J Addict Med 14:e6-e7. https://doi.org/10.1097/ ADM.0000000000000684

Khurdayan VK, Buch S, El-Hage N, Lutz SE, Goebel SM, Singh IN, Knapp PE, Turchan-Cholewo J, Nath A, Hauser KF (2004) Preferential vulnerability of astroglia and glial precursors to combined opioid and HIV-1 Tat exposure in vitro. Eur J Neurosci 19: 3171-3182

Kibaly C, Xu C, Cahill CM, Evans CJ, Law P-Y (2018) Non-nociceptive roles of opioids in the CNS: opioids' effects on neurogenesis, learning, memory and affect. Nat Rev Neurosci 20:5-18

Kieffer BL, Gaveriaux-Ruff C (2002) Exploring the opioid system by gene knockout. Prog Neurobiol 66:285-306

Kim S, Hahn YK, Podhaizer EM, McLane VD, Zou S, Hauser KF, Knapp PE (2018) A central role for glial CCR5 in directing the neuropathological interactions of HIV-1 Tat and opiates. J Neuroinflammation 15:285

Kimura-Kuroda J, Nagashima K, Yasui K (1994) Inhibition of myelin formation by HIV-1 gp120 in rat cerebral cortex culture. Arch Virol 137:81-99

Kish SJ, Kalasinsky KS, Derkach P, Schmunk GA, Guttman M, Ang L, Adams V, Furukawa Y, Haycock JW (2001) Striatal dopaminergic and serotonergic markers in human heroin users. Neuropsychopharmacology 24:561-567

Knapp PE, Hauser KF (1996) $\mu$-Opioid receptor activation enhances DNA synthesis in immature oligodendrocytes. Brain Res 743: 341-345

Knapp PE, Maderspach K, Hauser KF (1998) Endogenous opioid system in developing normal and jimpy oligodendrocytes: $\mu$ and $\kappa$ opioid receptors mediate differential mitogenic and growth responses. Glia 22:189-201

Knapp PE, Itkis OS, Zhang L, Spruce BA, Bakalkin G, Hauser KF (2001) Endogenous opioids and oligodendroglial function: possible autocrine/paracrine effects on cell survival and development. Glia $35: 156-165$

Knapp PE, Adjan VV, Hauser KF (2009) Cell-specific loss of K-opioid receptors in oligodendrocytes of the dysmyelinating jimpy mouse. Neurosci Lett 451:114-118

Ko A, Kang G, Hattler JB, Galadima HI, Zhang J, Li Q, Kim WK (2019) Macrophages but not Astrocytes Harbor HIV DNA in the brains of HIV-1-infected Aviremic individuals on suppressive antiretroviral therapy. J NeuroImmune Pharmacol 14:110-119

Kodaira H, Kusuhara H, Fujita T, Ushiki J, Fuse E, Sugiyama Y (2011) Quantitative evaluation of the impact of active efflux by P-glycoprotein and breast cancer resistance protein at the blood-brain barrier on the predictability of the unbound concentrations of drugs in the brain using cerebrospinal fluid concentration as a surrogate. J Pharmacol Exp Ther 339:935-944
Kodaira H, Kusuhara H, Fuse E, Ushiki J, Sugiyama Y (2014) Quantitative investigation of the brain-to-cerebrospinal fluid unbound drug concentration ratio under steady-state conditions in rats using a pharmacokinetic model and scaling factors for active efflux transporters. Drug Metab Dispos 42:983-989

Kolodyny A, Courtwright DT, Hwang CS, Kreiner P, Eadie JL, Clark TW, Alexander GC (2015) The prescription opioid and heroin crisis: a public health approach to an epidemic of addiction. Annu Rev Public Health 36:559-574

Koob GF (2020) Neurobiology of opioid addiction: opponent process, Hyperkatifeia, and negative reinforcement. Biol Psychiatry 87:44 53

Koob G, Kreek MJ (2007) Stress, dysregulation of drug reward pathways, and the transition to drug dependence. Am J Psychiatry 164: 1149-1159

Koob GF, Volkow ND (2016) Neurobiology of addiction: a neurocircuitry analysis. Lancet Psychiatry 3:760-773

Kostrikis LG, Huang Y, Moore JP, Wolinsky SM, Zhang L, Guo Y, Deutsch L, Phair J, Neumann AU, Ho DD (1998) A chemokine receptor CCR2 allele delays HIV-1 disease progression and is associated with a CCR5 promoter mutation. Nat Med 4:350-353

Kovacs GG, Horvath MC, Majtenyi K, Lutz MI, Hurd YL, Keller E (2015) Heroin abuse exaggerates age-related deposition of hyperphosphorylated tau and p62-positive inclusions. Neurobiol Aging 36:3100-3107

Kramer-Hammerle S, Rothenaigner I, Wolff H, Bell JE, Brack-Werner R (2005) Cells of the central nervous system as targets and reservoirs of the human immunodeficiency virus. Virus Res 111:194-213

Krathwohl MD, Kaiser JL (2004) HIV-1 promotes quiescence in human neural progenitor cells. J Infect Dis 190:216-226

Kreek MJ (1973) Medical safety and side effects of methadone in tolerant individuals. JAMA 223:665-668

Kreek MJ (1987) Tolerance and dependence: implications for the pharmacological treatment of addiction. NIDA Res Monogr 76:53-62

Kreek MJ (2001) Drug addictions. Molecular and cellular endpoints. Ann N Y Acad Sci 937:27-49

Kreek MJ (2007) Opioids, dopamine, stress, and the addictions. Dialogues Clin Neurosci 9:363-378

Kreek MJ, LaForge KS, Butelman E (2002) Pharmacotherapy of addictions. Nat Rev Drug Discov 1:710-726

Kreek MJ, Bart G, Lilly C, LaForge KS, Nielsen DA (2005) Pharmacogenetics and human molecular genetics of opiate and cocaine addictions and their treatments. Pharmacol Rev 57:1-26

Kringen MK, Chalabianloo F, Bernard JP, Bramness JG, Molden E, Hoiseth G (2017) Combined effect of CYP2B6 genotype and other candidate genes on a steady-state serum concentration of methadone in opioid maintenance treatment. Ther Drug Monit 39:550-555

Krishnan G, Chatterjee N (2015) Differential immune mechanism to HIV-1 Tat variants and its regulation by AEA [corrected]. Sci Rep 5:9887

Kuhlman JJ Jr, Lalani S, Magluilo J Jr, Levine B, Darwin WD (1996) Human pharmacokinetics of intravenous, sublingual, and buccal buprenorphine. J Anal Toxicol 20:369-378

Kumar R, Orsoni S, Norman L, Verma AS, Tirado G, Giavedoni LD, Staprans S, Miller GM, Buch SJ, Kumar A (2006) Chronic morphine exposure causes pronounced virus replication in cerebral compartment and accelerated onset of AIDS in SIV/SHIV-infected Indian rhesus macaques. Virology 354:192-206

Kwiatkowski CF, Booth RE (2001) Methadone maintenance as HIV risk reduction with street-recruited injecting drug users. J Acquir Immune Defic Syndr 26:483-489 
Lacagnina MJ, Rivera PD, Bilbo SD (2017) Glial and neuroimmune mechanisms as critical modulators of drug use and abuse. Neuropsychopharmacology 42:156-177

Lama J, Planelles V (2007) Host factors influencing susceptibility to HIV infection and AIDS progression. Retrovirology 4:52

Langford TD, Letendre SL, Marcotte TD, Ellis RJ, JA MC, Grant I, Mallory ME, Hansen LA, Archibald S, Jernigan T, Masliah E, Group H (2002) Severe, demyelinating leukoencephalopathy in AIDS patients on antiretroviral therapy. AIDS 16:1019-1029

Lapierre J, Rodriguez M, Ojha CR, El-Hage N (2018) Critical role of Beclin1 in HIV Tat and morphine-induced inflammation and calcium release in glial cells from autophagy deficient mouse. J NeuroImmune Pharmacol 13:355-370

Lawlor PG (2002) The panorama of opioid-related cognitive dysfunction in patients with cancer: a critical literature appraisal. Cancer 94: 1836-1853

Lawrence DM, Durham LC, Schwartz L, Seth P, Maric D, Major EO (2004) Human immunodeficiency virus type 1 infection of human brain-derived progenitor cells. J Virol 78:7319-7328

Lee MH, Amin ND, Venkatesan A, Wang T, Tyagi R, Pant HC, Nath A (2013) Impaired neurogenesis and neurite outgrowth in an HIVgp120 transgenic model is reversed by exercise via BDNF production and Cdk5 regulation. J Neurovirol 19:418-431

Leibrand CR, Paris JJ, Ghandour MS, Knapp PE, Kim WK, Hauser KF, McRae M (2017) HIV-1 tat disrupts blood-brain barrier integrity and increases phagocytic perivascular macrophages and microglia in the dorsal striatum of transgenic mice. Neurosci Lett 640:136143

Leibrand CR, Paris JJ, Jones AM, Masuda QN, Halquist MS, Kim WK, Knapp PE, Kashuba ADM, Hauser KF, McRae M (2019) HIV-1 Tat and opioids act independently to limit antiretroviral brain concentrations and reduce blood-brain barrier integrity. J Neurovirol 25:560 577

Leite SC, Correa DG, Doring TM, Kubo TT, Netto TM, Ferracini R, Ventura N, Bahia PR, Gasparetto EL (2013) Diffusion tensor MRI evaluation of the corona radiata, cingulate gyri, and corpus callosum in HIV patients. J Magn Reson Imaging 38:1488-1493

Lemons A, DeGroote N, Perez A, Craw J, Nyaku M, Broz D, Mattson CL, Beer L (2019) Opioid misuse among HIV-positive adults in medical care: results from the medical monitoring project, 20092014. J Acquir Immune Defic Syndr 80:127-134

Leopoldt D, Hanck T, Exner T, Maier U, Wetzker R, Nurnberg B (1998) $\mathrm{G} \beta \gamma$ stimulates phosphoinositide 3-kinase- $\gamma$ by direct interaction with two domains of the catalytic p110 subunit. J Biol Chem 273: 7024-7029

Leppla IE, Gross MS (2020) Optimizing medication treatment of opioid use disorder during COVID-19 (SARS-CoV-2). J Addict Med 14: e1-e3. https://doi.org/10.1097/ADM.0000000000000678.

Lerner AM, Fauci AS (2019) Opioid injection in rural areas of the United States: a potential obstacle to ending the HIV epidemic. JAMA 322: 1041-1042. https://doi.org/10.1001/jama.2019.10657.

Leshner AI (1998) HIV prevention with drug using populations. Current status and future prospects. Public Health Rep 113 Suppl 1:1-3

Li M, Ransohoff RM (2008) Multiple roles of chemokine CXCL12 in the central nervous system: a migration from immunology to neurobiology. Prog Neurobiol 84:116-131

Li W, Huang Y, Reid R, Steiner J, Malpica-Llanos T, Darden TA, Shankar SK, Mahadevan A, Satishchandra P, Nath A (2008) NMDA receptor activation by HIV-Tat protein is clade dependent. J Neurosci 28:12190-12198

Li W, Li Q, Zhu J, Qin Y, Zheng Y, Chang H, Zhang D, Wang H, Wang L, Wang Y, Wang W (2013) White matter impairment in chronic heroin dependence: a quantitative DTI study. Brain Res 1531:58-64
Li GH, Anderson C, Jaeger L, Do T, Major EO, Nath A (2015) Cell-tocell contact facilitates HIV transmission from lymphocytes to astrocytes via CXCR4. AIDS 29:755-766

Li W, Li Q, Wang Y, Zhu J, Ye J, Yan X, Li Y, Chen J, Liu J, Li Z, Wang W, Liu Y (2016) Methadone-induced damage to white matter integrity in methadone maintenance patients: a longitudinal self-control DTI study. Sci Rep 6:19662

Li GH, Maric D, Major EO, Nath A (2020) Productive HIV infection in astrocytes can be established via a non-classical mechanism. AIDS 34:963-978

Liang DY, Clark JD (2004) Modulation of the NO/CO-cGMP signaling cascade during chronic morphine exposure in mice. Neurosci Lett 365:73-77

Liu R, Paxton WA, Choe S, Ceradini D, Martin SR, Horuk R, MacDonald ME, Stuhlmann H, Koup RA, Landau NR (1996) Homozygous defect in HIV-1 coreceptor accounts for resistance of some multiply-exposed individuals to HIV-1 infection. Cell 86: 367-377

Liu H et al (1999) Polymorphism in RANTES chemokine promoter affects HIV-1 disease progression. Proc Natl Acad Sci U S A 96: $4581-4585$

Liu Y, Liu H, Kim BO, Gattone VH, Li J, Nath A, Blum J, He JJ (2004) CD4-independent infection of astrocytes by human immunodeficiency virus type 1: requirement for the human mannose receptor. J Virol 78:4120-4133

Liu X, Smith BJ, Chen C, Callegari E, Becker SL, Chen X, Cianfrogna J, Doran AC, Doran SD, Gibbs JP, Hosea N, Liu J, Nelson FR, Szewc MA, Van Deusen J (2006) Evaluation of cerebrospinal fluid concentration and plasma free concentration as a surrogate measurement for brain free concentration. Drug Metab Dispos 34: $1443-1447$

Liu WT, Han Y, Liu YP, Song AA, Barnes B, Song XJ (2010) Spinal matrix metalloproteinase-9 contributes to physical dependence on morphine in mice. J Neurosci 30:7613-7623

Liu B, Liu X, Tang SJ (2016a) Interactions of opioids and HIV infection in the pathogenesis of chronic pain. Front Microbiol 7:103

Liu H, Xu E, Liu J, Xiong H (2016b) Oligodendrocyte injury and pathogenesis of HIV-1-associated neurocognitive disorders. Brain Sci 6:23

Liu H, Liu J, Xu E, Tu G, Guo M, Liang S, Xiong H (2017) Human immunodeficiency virus protein Tat induces oligodendrocyte injury by enhancing outward $\mathrm{K}^{+}$current conducted by $\mathrm{K}_{\mathrm{V}} 1.3$. Neurobiol Dis 97:1-10

Low KG, Allen RG, Melner MH (1992) Differential regulation of proenkephalin expression in astrocytes by cytokines. Endocrinology 131:1908-1914

Low AJ, Mburu G, Welton NJ, May MT, Davies CF, French C, Turner KM, Looker KJ, Christensen H, McLean S, Rhodes T, Platt L, Hickman M, Guise A, Vickerman P (2016) Impact of opioid substitution therapy on antiretroviral therapy outcomes: a systematic review and meta-analysis. Clin Infect Dis 63:1094-1104

Lu Z, Xu J, Rossi GC, Majumdar S, Pasternak GW, Pan YX (2015) Mediation of opioid analgesia by a truncated 6-transmembrane GPCR. J Clin Invest 125:2626-2630

MacArthur GJ, Minozzi S, Martin N, Vickerman P, Deren S, Bruneau J, Degenhardt L, Hickman M (2012) Opiate substitution treatment and HIV transmission in people who inject drugs: systematic review and meta-analysis. BMJ 345:e5945

Maduna T, Audouard E, Dembele D, Mouzaoui N, Reiss D, Massotte D, Gaveriaux-Ruff C (2018) Microglia express mu opioid receptor: insights from transcriptomics and fluorescent reporter mice. Frontiers in psychiatry 9:726

Mahajan SD, Schwartz SA, Shanahan TC, Chawda RP, Nair MP (2002) Morphine regulates gene expression of $\alpha$ - and $\beta$-chemokines and 
their receptors on astroglial cells via the opioid $\mu$ receptor. $\mathrm{J}$ Immunol 169:3589-3599

Mahajan SD, Schwartz SA, Aalinkeel R, Chawda RP, Sykes DE, Nair MP (2005) Morphine modulates chemokine gene regulation in normal human astrocytes. Clin Immunol 115:323-332

Mahajan SD, Aalinkeel R, Sykes DE, Reynolds JL, Bindukumar B, Fernandez SF, Chawda R, Shanahan TC, Schwartz SA (2008) Tight junction regulation by morphine and HIV-1 Tat modulates blood-brain barrier permeability. J Clin Immunol 28:528-541

Malik S, Khalique H, Buch S, Seth P (2011) A growth factor attenuates HIV-1 Tat and morphine induced damage to human neurons: implication in HIV/AIDSdrug abuse cases. PLoS One 6:e18116

Malik S, Saha R, Seth P (2014) Involvement of extracellular signalregulated kinase (ERK1/2)-p53-p21 axis in mediating neural stem/progenitor cell cycle arrest in co-morbid HIV-drug abuse exposure. J NeuroImmune Pharmacol 9:340-353

Marcario JK, Riazi M, Adany I, Kenjale H, Fleming K, Marquis J, Nemon O, Mayo MS, Yankee T, Narayan O, Cheney PD (2008) Effect of morphine on the neuropathogenesis of SIVmac infection in Indian rhesus macaques. J NeuroImmune Pharmacol 3:12-25

Marcario JK, Pendyala G, Riazi M, Fleming K, Marquis J, Callen S, Lisco SJ, Fowler SC, Cheney PD, Buch SJ (2016) Effects of morphine on behavioral task performance in SIV-infected rhesus macaques. J NeuroImmune Pharmacol 11:348-357

Marinho AT, Miranda JP, Caixas U, Charneira C, Goncalves-Dias C, Marques MM, Monteiro EC, Antunes AMM, Pereira SA (2019) Singularities of nevirapine metabolism: from sex-dependent differences to idiosyncratic toxicity. Drug Metab Rev 51:76-90

Martin E, Keutmann MK, Fogel JS, Maki PM, Gonzalez R, Vassileva J, Rubin LH, Hardy D (2018) Verbal and spatial working memory among drug-using HIVinfected men and women. J NeuroVirol 24: 488-497

Martin EM, Gonzalez R, Vassileva J, Bechara A (2019) Double dissociation of HIV and substance use disorder effects on neurocognitive tasks dependent on striatal integrity. AIDS 33:1863-1870

Martin-Thormeyer EM, Paul RH (2009) Drug abuse and hepatitis C infection as comorbid features of HIV associated neurocognitive disorder: neurocognitive and neuroimaging features. Neuropsychol Rev 19:215-231

Marzolini C, Troillet N, Telenti A, Baumann P, Decosterd LA, Eap CB (2000) Efavirenz decreases methadone blood concentrations. AIDS 14:1291-1292

Maschke M, Kastrup O, Esser S, Ross B, Hengge U, Hufnagel A (2000) Incidence and prevalence of neurological disorders associated with HIV since the introduction of highly active antiretroviral therapy (HAART). J Neurol Neurosurg Psychiatry 69:376-380

Massaly N, Frances B, Mouledous L (2014) Roles of the ubiquitin proteasome system in the effects of drugs of abuse. Front Mol Neurosci 7:99

Masvekar RR, El-Hage N, Hauser KF, Knapp PE (2014) Morphine enhances $\mathrm{HIV}-1_{\mathrm{SF} 162}$-mediated neuron death and delays recovery of injured neurites. PLoS One 9:e100196

Mathers BM, Degenhardt L, Bucello C, Lemon J, Wiessing L, Hickman M (2013) Mortality among people who inject drugs: a systematic review and meta-analysis. Bull World Health Organ 91:102-123

Mathews JL, Smrcka AV, Bidlack JM (2008) A novel G $\beta \gamma$-subunit inhibitor selectively modulates $\mu$-opioid-dependent antinociception and attenuates acute morphine-induced antinociceptive tolerance and dependence. J Neurosci 28:12183-12189

Matsunaga M, Isowa T, Murakami H, Kasugai K, Yoneda M, Kaneko H, Ohira H (2009) Association of polymorphism in the human muopioid receptor OPRM1 gene with proinflammatory cytokine levels and health perception. Brain Behav Immun 23:931-935
Mattioli TA, Leduc-Pessah H, Skelhorne-Gross G, Nicol CJ, Milne B, Trang T, Cahill CM (2014) Toll-like receptor 4 mutant and null mice retain morphine-induced tolerance, hyperalgesia, and physical dependence. PLoS One 9:e97361

Mazhnaya A, Marcus R, Bojko MJ, Zelenev A, Makarenko I, Pykalo I, Filippovych S, Dvoriak S, Altice FL (2018) Opioid agonist treatment and improved outcomes at each stage of the HIV treatment cascade in people who inject drugs in Ukraine. J Acquir Immune Defic Syndr 79:288-295

McArthur JC, Steiner J, Sacktor N, Nath A (2010) Human immunodeficiency virus-associated neurocognitive disorders: mind the gap. Ann Neurol 67:699-714

McCance-Katz EF (2005) Treatment of opioid dependence and coinfection with HIV and hepatitis $\mathrm{C}$ virus in opioid-dependent patients: the importance of drug interactions between opioids and antiretroviral agents. Clin Infect Dis 41(Suppl 1):S89-S95

McCance-Katz EF, Moody DE, Morse GD, Ma Q, DiFrancesco R, Friedland G, Pade P, Rainey PM (2007) Interaction between buprenorphine and atazanavir or atazanavir/ritonavir. Drug Alcohol Depend 91:269-278

McDermott DH, Beecroft MJ, Kleeberger CA, Al-Sharif FM, Ollier WE, Zimmerman PA, Boatin BA, Leitman SF, Detels R, Hajeer AH, Murphy PM (2000) Chemokine RANTES promoter polymorphism affects risk of both HIV infection and disease progression in the multicenter AIDS cohort study. AIDS 14:2671-2678

McDonough RJ, Madden JJ, Falek A, Shafer DA, Pline M, Gordon D, Bokos P, Kuehnle JC, Mendelson J (1980) Alteration of T and null lymphocyte frequencies in the peripheral blood of human opiate addicts: in vivo evidence for opiate receptor sites on $\mathrm{T}$ lymphocytes. J Immunol 125:2539-2543

McDonough RJ, Madden JJ, Rosman HS, Falek A, Wenger NK, Shafer DA, Bokos PJ, Kuehnle JC, Mendelson JH (1981) Opiate inhibition of sheep erythrocyte binding to $\mathrm{T}$ lymphocytes: reversal by naloxone and cyclic nucleotides. NIDA Res Monogr 34:159-165

McLane VD, Cao L, Willis CL (2014) Morphine increases hippocampal viral load and suppresses frontal lobe CCL5 expression in the LPBM5 AIDS model. J Neuroimmunol 269:44-51

McLane VD, Kumar S, Leeming R, Rau S, Willis CL, Cao L (2018) Morphine-potentiated cognitive deficits correlate to suppressed hippocampal iNOS RNA expression and an absent type 1 interferon response in LP-BM5 murine AIDS. J Neuroimmunol 319:117-129

McLennan GP, Kiss A, Miyatake M, Belcheva MM, Chambers KT, Pozek JJ, Mohabbat Y, Moyer RA, Bohn LM, Coscia CJ (2008) Kappa opioids promote the proliferation of astrocytes via $G \beta \gamma$ and $\beta$-arrestin 2-dependent MAPK-mediated pathways. J Neurochem 107:1753-1765

McPherson J, Rivero G, Baptist M, Llorente J, Al-Sabah S, Krasel C, Dewey WL, Bailey CP, Rosethorne EM, Charlton SJ, Henderson G, Kelly E (2010) Mu-opioid receptors: correlation of agonist efficacy for signalling with ability to activate internalization. Mol Pharmacol 78:756-766

Meemken L, Hanhoff N, Tseng A, Christensen S, Gillessen A (2015) Drug-drug interactions with antiviral agents in people who inject drugs requiring substitution therapy. Ann Pharmacother 49:796807

Meijerink H, Wisaksana R, Iskandar S, den Heijer M, van der Ven AJ, Alisjahbana B, van Crevel R (2014) Injecting drug use is associated with a more rapid CD4 cell decline among treatment naive HIVpositive patients in Indonesia. J Int AIDS Soc 17:18844

Meijerink H, Indrati AR, Soedarmo S, Utami F, de Jong CA, Alisjahbana B, van Crevel R, Wisaksana R, Van der Ven AJ (2015) Heroin use in Indonesia is associated with higher 
expression of CCR5 on CD4+ cells and lower ex-vivo production of CCR5 ligands. AIDS 29:385-388

Meng J, Sindberg GM, Roy S (2015) Disruption of gut homeostasis by opioids accelerates HIV disease progression. Front Microbiol 6:643

Meyer UA, Zanger UM (1997) Molecular mechanisms of genetic polymorphisms of drug metabolism. Annu Rev Pharmacol Toxicol 37: 269-296

Meyer VJ, Rubin LH, Martin E, Weber KM, Cohen MH, Golub ET, Valcour V, Young MA, Crystal H, Anastos K, Aouizerat BE, Milam J, Maki PM (2013) HIV and recent illicit drug use interact to affect verbal memory in women. J Acquir Immune Defic Syndr 63:67-76

Midde NM, Gomez AM, Zhu J (2012) HIV-1 Tat protein decreases dopamine transporter cell surface expression and vesicular monoamine transporter-2 function in rat striatal synaptosomes. J NeuroImmune Pharmacol 7:629-639

Midde NM, Yuan Y, Quizon PM, Sun WL, Huang X, Zhan CG, Zhu J (2015) Mutations at tyrosine 88, lysine 92 and tyrosine 470 of human dopamine transporter result in an attenuation of HIV-1 Tatinduced inhibition of dopamine transport. J NeuroImmune Pharmacol 10:122-135

Mirsattari SM, Power C, Nath A (1999) Primary headaches with HIV infection. Headache 39:3-10

Mishra R, Singh SK (2014) HIV-1 tat C phosphorylates VE-cadherin complex and increases human brain microvascular endothelial cell permeability. BMC Neurosci 15:80

Mishra M, Vetrivel S, Siddappa NB, Ranga U, Seth P (2008) Cladespecific differences in neurotoxicity of human immunodeficiency virus-1 B and $\mathrm{C}$ tat of human neurons: significance of dicysteine C30C31 motif. Ann Neurol 63:366-376

Mishra M, Taneja M, Malik S, Khalique H, Seth P (2010) Human immunodeficiency virus type 1 Tat modulates proliferation and differentiation of human neural precursor cells: implication in NeuroAIDS. J NeuroVirol 16:355-367

Moises HC, Rusin KI, Macdonald RL (1994) Mu- and kappa-opioid receptors selectively reduce the same transient components of high-threshold calcium current in rat dorsal root ganglion sensory neurons. J Neurosci 14:5903-5916

Moore P, Dimsdale JE (2002) Opioids, sleep, and cancer-related fatigue. Med Hypotheses 58:77-82

Morales Odia Y, Jinka M, Ziai WC (2010) Severe leukoencephalopathy following acute oxycodone intoxication. Neurocrit Care 13:93-97

Morgan MM, Christie MJ (2011) Analysis of opioid efficacy, tolerance, addiction and dependence from cell culture to human. Br J Pharmacol 164:1322-1334

Mukandavire C, Low A, Mburu G, Trickey A, May MT, Davies CF, French CE, Looker KJ, Rhodes T, Platt L, Guise A, Hickman M, Vickerman P (2017) Impact of opioid substitution therapy on the HIV prevention benefit of antiretroviral therapy for people who inject drugs. AIDS 31:1181-1190

Muller UJ, Truebner K, Schiltz K, Kuhn J, Mawrin C, Dobrowolny H, Bernstein HG, Bogerts B, Steiner J (2015) Postmortem volumetric analysis of the nucleus accumbens in male heroin addicts: implications for deep brain stimulation. Eur Arch Psychiatry Clin Neurosci 265:647-653

Muller UJ, Schiltz K, Mawrin C, Dobrowolny H, Frodl T, Bernstein HG, Bogerts B, Truebner K, Steiner J (2018) Total hypothalamic volume is reduced in postmortem brains of male heroin addicts. Eur Arch Psychiatry Clin Neurosci 268:243-248

Muller UJ, Mawrin C, Frodl T, Dobrowolny H, Busse S, Bernstein HG, Bogerts B, Truebner K, Steiner J (2019) Reduced volumes of the external and internal globus pallidus in male heroin addicts: a postmortem study. Eur Arch Psychiatry Clin Neurosci 269:317-324
Murphy A, Barbaro J, Martinez-Aguado P, Chilunda V, JaureguiberryBravo M, Berman JW (2019) The effects of opioids on HIV Neuropathogenesis. Front Immunol 10:2445

Nam H, Chandra R, Francis TC, Dias C, Cheer JF, Lobo MK (2019) Reduced nucleus accumbens enkephalins underlie vulnerability to social defeat stress. Neuropsychopharmacology 44:1876-1885

Nandhu MS, Naijil G, Smijin S, Jayanarayanan S, Paulose CS (2010) Opioid system functional regulation in neurological disease management. J Neurosci Res 88:3215-3221

Narasipura SD, Kim S, Al-Harthi L (2014) Epigenetic regulation of HIV1 latency in astrocytes. J Virol 88:3031-3038

Narita M, Miyatake M, Narita M, Shibasaki M, Shindo K, Nakamura A, Kuzumaki N, Nagumo Y, Suzuki T (2006) Direct evidence of astrocytic modulation in the development of rewarding effects induced by drugs of abuse. Neuropsychopharmacology 31:2476-2488

Nash B, Meucci O (2014) Functions of the chemokine receptor CXCR in the central nervous system and its regulation by $\mu$-opioid receptors. Int Rev Neurobiol 118:105-128

Nath A (1999) Pathobiology of human immunodeficiency virus dementia. Semin Neurol 19:113-127

Nath A (2015) Eradication of human immunodeficiency virus from brain reservoirs. J NeuroVirol 21:227-234

Nath A, Booze RM, Hauser KF, Mactutus CF, Bell JE, Maragos WF, Berger JR (1999) Critical questions for neuroscientists in interactions of drugs of abuse and HIV infection. NeuroAIDS 2:1-12

Nath A, Jones M, Maragos W, Booze R, Mactutus C, Bell J, Hauser KF, Mattson M (2000a) Neurotoxicity and dysfunction of dopamine systems associated with AIDS dementia. Psychopharmacol 14: 222-227

Nath A, Anderson C, Jones M, Maragos W, Booze R, Mactutus C, Bell J, Hauser KF, Mattson M (2000b) Neurotoxicity and dysfunction of dopaminergic systems associated with AIDS dementia. J Psychopharmacol 14:222-227

Nath A, Hauser KF, Wojna V, Booze RM, Maragos W, Prendergast M, Cass W, Turchan JT (2002) Molecular basis for interactions of HIV and drugs of abuse. J Acquir Immune Defic Syndr 31(Suppl 2):S62-S69

NIDA (2020) COVID-19: Potential implications for individuals with substance use disorders. In: (Volkow ND, ed) Nora's Blog. National Institute on Drug Abuse (NIDA). 4/6/2020: https://www. drugabuse.gov/about-nida/noras-blog/2020/04/covid-19-potentialimplications-individuals-substance-use-disorders

Nieminen TH, Hagelberg NM, Saari TI, Neuvonen M, Neuvonen PJ, Laine K, Olkkola KT (2010) Oxycodone concentrations are greatly increased by the concomitant use of ritonavir or lopinavir/ritonavir. Eur J Clin Pharmacol 66:977-985

Noble F, Marie N (2018) Management of opioid addiction with opioid substitution treatments: beyond methadone and buprenorphine. Frontiers in psychiatry 9:742

Noel RJ Jr, Kumar A (2006) Virus replication and disease progression inversely correlate with SIV Tat evolution in morphine-dependent and SIV/SHIV-infected Indian rhesus macaques. Virology 346: $127-138$

Noel RJ Jr, Kumar A (2007) SIV Vpr evolution is inversely related to disease progression in a morphine-dependent rhesus macaque model of AIDS. Virology 359:397-404

Noel RJ Jr, Toro-Bahamonde A, Marrero-Otero Z, Orsini S, Verma AS, Kumar R, Kumar A (2006a) Lack of correlation between SIV-Nef evolution and rapid disease progression in morphine-dependent nonhuman primate model of AIDS. AIDS Res Hum Retrovir 22: $817-823$

Noel RJ Jr, Marrero-Otero Z, Kumar R, Chompre-Gonzalez GS, Verma AS, Kumar A (2006b) Correlation between SIV tat evolution and 
AIDS progression in cerebrospinal fluid of morphine-dependent and control macaques infected with SIV and SHIV. Virology 349: $440-452$

Nosyk B, Min JE, Colley G, Lima VD, Yip B, Milloy MJ, Wood E, Montaner JS (2015) The causal effect of opioid substitution treatment on HAART medication refill adherence. AIDS 29:965-973

Nottet HS, Persidsky Y, Sasseville VG, Nukuna AN, Bock P, Zhai QH, Sharer LR, McComb RD, Swindells S, Soderland C, Gendelman HE (1996) Mechanisms for the transendothelial migration of HIV1-infected monocytes into brain. J Immunol 156:1284-1295

Novick DM, Ochshorn M, Kreek MJ (1991) In vivo and in vitro studies of opiates and cellular immunity in narcotic addicts. Adv Exp Med Biol 288:159-170

Nukuzuma S, Kameoka M, Sugiura S, Nakamichi K, Nukuzuma C, Miyoshi I, Takegami T (2012) Exogenous human immunodeficiency virus- 1 protein, Tat, enhances replication of JC virus efficiently in neuroblastoma cell lines. J Med Virol 84:555-561

Oehmichen M, Meissner C, Reiter A, Birkholz M (1996) Neuropathology in non-human immunodeficiency virus-infected drug addicts: hypoxic brain damage after chronic intravenous drug abuse. Acta Neuropathol 91:642-646

Offiah C, Hall E (2008) Heroin-induced leukoencephalopathy: characterization using MRI, diffusion-weighted imaging, and MR spectroscopy. Clin Radiol 63:146-152

Okamoto S, Kang YJ, Brechtel CW, Siviglia E, Russo R, Clemente A, Harrop A, McKercher S, Kaul M, Lipton SA (2007) HIV/gp120 decreases adult neural progenitor cell proliferation via checkpoint kinase-mediated cell-cycle withdrawal and G1 arrest. Cell Stem Cell $1: 230-236$

Pallinger E, Csaba G (2008) A hormone map of human immune cells showing the presence of adrenocorticotropic hormone, triiodothyronine and endorphin in immunophenotyped white blood cells. Immunology 123:584-589

Paris JJ, Liere P, Kim S, Mahdi F, Buchanan ME, Nass SR, Qrareya AN, Salahuddin MF, Pianos A, Fernandez N, Shariat-Madar Z, Knapp PE, Schumacher M, Hauser KF (2020) Pregnane steroidogenesis is altered by HIV-1 Tat and morphine: physiological allopregnanolone is protective against neurotoxic and psychomotor effects. Neurobiol Stress 12:100211

Pasternak GW (2004) Multiple opiate receptors: deja vu all over again. Neuropharmacology 47(Suppl 1):312-323

Pasternak GW (2014) Opioids and their receptors: are we there yet? Neuropharmacology 76 Pt B:198-203

Pasternak GW, Pan YX (2013) Mu opioids and their receptors: evolution of a concept. Pharmacol Rev 65:1257-1317

Pasternak GW, Kolesnikov YA, Babey AM (1995) Perspectives on the $\mathrm{N}$-methyl-D-aspartate/nitric oxide cascade and opioid tolerance. Neuropsychopharmacology 13:309-313

Patel S, Leibrand CR, Palasuberniam P, Couraud PO, Weksler B, Jahr FM, McClay JL, Hauser KF, McRae M (2017) Effects of HIV-1 Tat and methamphetamine on blood-brain barrier integrity and function in vitro. Antimicrob Agents Chemother 61:e01307-e1317

Patel SH, Ismaiel OA, Mylott WR Jr, Yuan M, McClay JL, Paris JJ, Hauser KF, McRae M (2019) Cell-type specific differences in antiretroviral penetration and the effects of HIV-1 Tat and morphine among primary human brain endothelial cells, astrocytes, pericytes, and microglia. Neurosci Lett 712:134475

Pello OM, Duthey B, Garcia-Bernal D, Rodriguez-Frade JM, Stein JV, Teixido J, Martinez C, Mellado M (2006) Opioids trigger $\alpha_{5} \beta_{2}$ integrin-mediated monocyte adhesion. J Immunol 176:1675-1685

Pendyala G, Periyasamy P, Callen S, Fox HS, Lisco SJ, Buch SJ (2015) Chronic SIV and morphine treatment increases heat shock protein 5 expression at the synapse. J Neuro-Oncol 21:592-598
Peng H, Whitney N, Wu Y, Tian C, Dou H, Zhou Y, Zheng J (2008) HIV-1-infected and/or immune-activated macrophage-secreted TNF- $\alpha$ affects human fetal cortical neural progenitor cell proliferation and differentiation. Glia 56:903-916

Peng H, Sun L, Jia B, Lan X, Zhu B, Wu Y, Zheng J (2011) HIV-1infected and immune-activated macrophages induce astrocytic differentiation of human cortical neural progenitor cells via the STAT3 pathway. PLoS One 6:e19439

Perez-Casanova A, Noel RJ Jr, Rivera-Amill V, Husain K, Kumar A (2007) Morphine-mediated deterioration of oxidative stress leads to rapid disease progression in SIV/SHIV-infected macaques. AIDS Res Hum Retrovir 23:1004-1007

Perez-Casanova A, Husain K, Noel RJ Jr, Rivera-Amill V, Kumar A (2008) Interaction of SIV/SHIV infection and morphine on plasma oxidant/antioxidant balance in macaque. Mol Cell Biochem 308: 169-175

Peters PJ et al (2016) HIV infection linked to injection use of oxymorphone in Indiana, 2014-2015. N Engl J Med 375:229-239

Peterson PK, Sharp BM, Gekker G, Portoghese PS, Sannerud K, Balfour $\mathrm{HH} \mathrm{Jr}$ (1990) Morphine promotes the growth of HIV-1 in human peripheral blood mononuclear cell cocultures. AIDS 4:869-873

Peterson PK, Gekker G, Hu S, Schoolov Y, Balfour HH Jr, Chao CC (1992) Microglial cell upregulation of HIV-1 expression in the chronically infected promonocytic cell line U1: the role of tumor necrosis factor-alpha. J Neuroimmunol 41:81-87

Peterson PK, Gekker G, Schut R, Hu S, Balfour HH Jr, Chao CC (1993) Enhancement of HIV-1 replication by opiates and cocaine: the cytokine connection. Adv Exp Med Biol 335:181-188

Peterson PK, Molitor TW, Chao CC (1998) The opioid-cytokine connection. J Neuroimmunol 83:63-69

Peterson PK, Gekker G, Hu S, Lokensgard J, Portoghese PS, Chao CC (1999) Endomorphin-1 potentiates HIV-1 expression in human brain cell cultures: implication of an atypical mu-opioid receptor. Neuropharmacology 38:273-278

Pettes T, Wood E, Guillemi S, Lai C, Montaner J, Kerr T (2010) Methadone use among HIV-positive injection drug users in a Canadian setting. J Subst Abus Treat 39:174-179

Pezawas LM, Fischer G, Diamant K, Schneider C, Schindler SD, Thurnher M, Ploechl W, Eder H, Kasper S (1998) Cerebral CT findings in male opioid-dependent patients: stereological, planimetric and linear measurements. Psychiatry Res 83:139-147

Pitcher J, Abt A, Myers J, Han R, Snyder M, Graziano A, Festa L, Kutzler M, Garcia F, Gao WJ, Fischer-Smith T, Rappaport J, Meucci O (2014) Neuronal ferritin heavy chain and drug abuse affect HIVassociated cognitive dysfunction. J Clin Invest 124:656-669

Platt L, Reed J, Minozzi S, Vickerman P, Hagan H, French C, Jordan A, Degenhardt L, Hope V, Hutchinson S, Maher L, Palmateer N, Taylor A, Hickman M (2016) Effectiveness of needle/syringe programmes and opiate substitution therapy in preventing HCV transmission among people who inject drugs. Cochrane Database Syst Rev 2016:CD012021

Plotnikoff NP (1988) Opioids: immunomodulators. A proposed role in cancer and aging. Ann N Y Acad Sci 521:312-322

Podhaizer EM, Zou S, Fitting S, Samano KL, El-Hage N, Knapp PE, Hauser KF (2012) Morphine and gp120 toxic interactions in striatal neurons are dependent on HIV-1 strain. J NeuroImmune Pharmacol $7: 877-891$

Polli JW, Jarrett JL, Studenberg SD, Humphreys JE, Dennis SW, Brouwer KR, Woolley JL (1999) Role of P-glycoprotein on the CNS disposition of amprenavir (141W94), an HIV protease inhibitor. Pharm Res 16:1206-1212 
Price RW, Brew B, Sidtis J, Rosenblum M, Scheck AC, Cleary P (1988) The brain in AIDS: central nervous system HIV-1 infection and AIDS dementia complex. Science 239:586-592

Protass LM (1971) Delayed postanoxic encephalopathy after heroin use. Ann Intern Med 74:738-739

Proudnikov D, Randesi M, Levran O, Crystal H, Dorn M, Ott J, Ho A, Kreek MJ (2012) Association of polymorphisms of the mu opioid receptor gene with the severity of HIV infection and response to HIV treatment. J Infect Dis 205:1745-1756

Proudnikov D, Randesi M, Levran O, Yuferov V, Crystal H, Ho A, Ott J, Kreek MJ (2013) Polymorphisms of the kappa opioid receptor and prodynorphin genes: HIV risk and HIV natural history. J Acquir Immune Defic Syndr 63:17-26

Puehler W, Rittner HL, Mousa SA, Brack A, Krause H, Stein C, Schafer M (2006) Interleukin-1 beta contributes to the upregulation of kappa opioid receptor mRNA in dorsal root ganglia in response to peripheral inflammation. Neuroscience 141:989-998

Purohit V, Rapaka RS, Rutter J, Shurtleff D (2012) Do opioids activate latent HIV-1 by down-regulating anti-HIV microRNAs? J NeuroImmune Pharmacol 7:519-523

Putatunda R, Zhang Y, Li F, Yang XF, Barbe MF, Hu W (2018) Adult neurogenic deficits in HIV-1 Tg26 transgenic mice. J Neuroinflammation 15:287

Putatunda R, Ho WZ, Hu W (2019) HIV-1 and compromised adult neurogenesis: emerging evidence for a new paradigm of HAND persistence. AIDS Rev 21:11-22

Qiu Y, Jiang G, Su H, Lv X, Zhang X, Tian J, Zhuo F (2013) Progressive white matter microstructure damage in male chronic heroin dependent individuals: a DTI and TBSS study. PLoS One 8:e63212

Qureshi A, Lee-Chiong T, Jr. (2004) Medications and their effects on sleep. The medical clinics of North America 88:751-766

Radja F, Kay DG, Albrecht S, Jolicoeur P (2003) Oligodendrocytespecific expression of human immunodeficiency virus type $1 \mathrm{Nef}$ in transgenic mice leads to vacuolar myelopathy and alters oligodendrocyte phenotype in vitro. J Virol 77:11745-11753

Ragin AB, Storey P, Cohen BA, Epstein LG, Edelman RR (2004) Whole brain diffusion tensor imaging in HIV-associated cognitive impairment. AJNR Am J Neuroradiol 25:195-200

Ragin AB, Wu Y, Storey P, Cohen BA, Edelman RR, Epstein LG (2005) Diffusion tensor imaging of subcortical brain injury in patients infected with human immunodeficiency virus. J Neurovirol 11(3): 292-298

Ramage SN, Anthony IC, Carnie FW, Busuttil A, Robertson R, Bell JE (2005) Hyperphosphorylated tau and amyloid precursor protein deposition is increased in the brains of young drug abusers. Neuropathol Appl Neurobiol 31:439-448

Ranga U, Shankarappa R, Siddappa NB, Ramakrishna L, Nagendran R, Mahalingam M, Mahadevan A, Jayasuryan N, Satishchandra P, Shankar SK, Prasad VR (2004) Tat protein of human immunodeficiency virus type 1 subtype $\mathrm{C}$ strains is a defective chemokine. J Virol 78:2586-2590

Rao VR, Sas AR, Eugenin EA, Siddappa NB, Bimonte-Nelson H, Berman JW, Ranga U, Tyor WR, Prasad VR (2008) HIV-1 cladespecific differences in the induction of neuropathogenesis. J Neurosci 28:10010-10016

Rao VR, Neogi U, Talboom JS, Padilla L, Rahman M, Fritz-French C, Gonzalez-Ramirez S, Verma A, Wood C, Ruprecht RM, Ranga U, Azim T, Joska J, Eugenin E, Shet A, Bimonte-Nelson H, Tyor WR, Prasad VR (2013) Clade C HIV-1 isolates circulating in southern Africa exhibit a greater frequency of dicysteine motif-containing tat variants than those in Southeast Asia and cause increased neurovirulence. Retrovirology 10:61
Rappaport J, Volsky DJ (2015) Role of the macrophage in HIV-associated neurocognitive disorders and other comorbidities in patients on effective antiretroviral treatment. J Neurovirol 21(3):235-241

Reddy PV, Pilakka-Kanthikeel S, Saxena SK, Saiyed Z, Nair MP (2012) Interactive effects of morphine on HIV infection: role in HIVassociated neurocognitive disorder. AIDS research and treatment 2012:953678

Regan PM, Dave RS, Datta PK, Khalili K (2012) Epigenetics of $\mu$-opioid receptors: intersection with HIV-1 infection of the central nervous system. J Cell Physiol 227:2832-2841

Rittner HL, Brack A, Machelska H, Mousa SA, Bauer M, Schafer M, Stein C (2001) Opioid peptide-expressing leukocytes: identification, recruitment, and simultaneously increasing inhibition of inflammatory pain. Anesthesiology 95:500-508

Rittner HL, Brack A, Stein C (2008) Pain and the immune system. Br J Anaesth 101:40-44

Rivera I, Garcia Y, Gangwani MR, Noel RJ Jr, Maldonado L, Kumar A, Rivera-Amill V (2013) Identification and molecular characterization of SIV Vpr R50G mutation associated with long term survival in SIV-infected morphine dependent and control macaques. Virology 446:144-151

Rivera-Amill V, Noel RJ Jr, Orsini S, Tirado G, Garcia JM, Buch S, Kumar A (2007) Variable region 4 of SIV envelope correlates with rapid disease progression in morphine-exposed macaques infected with SIV/SHIV. Virology 358:373-383

Rivera-Amill V, Silverstein PS, Noel RJ Jr, Kumar S, Kumar A (2010a) Morphine and rapid disease progression in nonhuman primate model of AIDS: inverse correlation between disease progression and virus evolution. J NeuroImmune Pharmacol 5:122-132

Rivera-Amill V, Noel RJ Jr, Garcia Y, Rivera I, Iszard M, Buch S, Kumar A (2010b) Accelerated evolution of SIV env within the cerebral compartment in the setting of morphine-dependent rapid disease progression. Virology 398:201-207

Roberts D, Wolfarth A, Sanchez C, Pehrson AL (2018) Frontal cortex dysfunction as a target for remediation in opiate use disorder: role in cognitive dysfunction and disordered reward systems. Prog Brain Res 239:179-227

Robinson-Papp J, Morgello S, Vaida F, Fitzsimons C, Simpson DM, Elliott KJ, Al-Lozi M, Gelman BB, Clifford D, Marra CM, McCutchan JA, Atkinson JH, Dworkin RH, Grant I, Ellis R (2010) Association of self-reported painful symptoms with clinical and neurophysiologic signs in HIV-associated sensory neuropathy. Pain 151:732-736

Rodriguez Salgado D, Rodriguez Alvarez M, Seoane Pesqueira G (2006) Neuropsychological impairment among asymptomatic HIVpositive former intravenous drug users. Cogn Behav Neurol 19: 95-104

Rodriguez M, Lapierre J, Ojha CR, Estrada-Bueno H, Dever SM, Gewirtz DA, Kashanchi F, El-Hage N (2017) Importance of autophagy in mediating human immunodeficiency virus (HIV) and morphine-induced metabolic dysfunction and inflammation in human astrocytes. Viruses 9:201

Rogers TJ, Peterson PK (2003) Opioid G protein-coupled receptors: signals at the crossroads of inflammation. Trends Immunol 24:116-121

Rogers TJ, Steele AD, Howard OM, Oppenheim JJ (2000) Bidirectional heterologous desensitization of opioid and chemokine receptors. Ann N Y Acad Sci 917:19-28

Rothenaigner I, Kramer S, Ziegler M, Wolff H, Kleinschmidt A, BrackWerner R (2007) Long-term HIV-1 infection of neural progenitor populations. AIDS 21:2271-2281

Rouveix B (1992) Opiates and immune function. Consequences on infectious diseases with special reference to AIDS. Therapie 47: 503-512 
Roy S, Wang J, Kelschenbach J, Koodie L, Martin J (2006) Modulation of immune function by morphine: implications for susceptibility to infection. J NeuroImmune Pharmacol 1:77-89

Royal W 3rd, Updike M, Selnes OA, Proctor TV, Nance-Sproson L, Solomon L, Vlahov D, Cornblath DR, McArthur JC (1991) HIV-1 infection and nervous system abnormalities among a cohort of intravenous drug users. Neurology 41:1905-1910

Rubin LH, Radtke KK, Eum S, Tamraz B, Kumanan KN, Springer G, Maki PM, Anastos K, Merenstein D, Karim R, Weber KM, Gustafson D, Greenblatt RM, Bishop JR (2018) Cognitive burden of common non-antiretroviral medications in HIV-infected women. J Acquir Immune Defic Syndr 79:83-91

Russell RA, Chojnacki J, Jones DM, Johnson E, Do T, Eggeling C, Padilla-Parra S, Sattentau QJ (2017) Astrocytes resist HIV-1 fusion but engulf infected macrophage material. Cell Rep 18:1473-1483

Ruzicka BB, Akil H (1997) The interleukin-1 $\beta$-mediated regulation of proenkephalin and opioid receptor messenger RNA in primary astrocyte-enriched cultures. Neuroscience 79:517-524

Ruzicka BB, Fox CA, Thompson RC, Meng F, Watson SJ, Akil H (1995) Primary astroglial cultures derived from several rat brain regions differentially express $\mu, \delta$, and $\kappa$ opioid receptor mRNA. Brain Res Mol Brain Res 34:209-220

Ryan LA, Brester M, Bohac D, Morgello S, Zheng J (2004) Upregulation of soluble tumor necrosis factor receptor two in plasma of HIV-seropositive individuals who use opiates. AIDS Res Hum Retrovir 20:41-45

Sacktor N, Nakasujja N, Skolasky RL, Rezapour M, Robertson K, Musisi S, Katabira E, Ronald A, Clifford DB, Laeyendecker O, Quinn TC (2009) HIV subtype D is associated with dementia, compared with subtype A, in immunosuppressed individuals at risk of cognitive impairment in Kampala, Uganda. Clin Infect Dis 49:780-786

Salahuddin MF, Qrareya AN, Mahdi F, Jackson D, Foster M, Vujanovic T, Box JG, Paris JJ (2020) Combined HIV-1 Tat and oxycodone activate the hypothalamic-pituitary-adrenal and -gonadal axes and promote psychomotor, affective, and cognitive dysfunction in female mice. Horm Behav 119:104649

Salvemini D (2009) Peroxynitrite and opiate antinociceptive tolerance: a painful reality. Arch Biochem Biophys 484:238-244

Samikkannu T, Agudelo M, Gandhi N, Reddy PV, Saiyed ZM, Nwankwo D, Nair MP (2011) Human immunodeficiency virus type 1 clade B and C gp 120 differentially induce neurotoxin arachidonic acid in human astrocytes: implications for neuroAIDS. J Neurovirol 17:230-238

Samoshkin A, Convertino M, Viet CT, Wieskopf JS, Kambur O, Marcovitz J, Patel P, Stone LS, Kalso E, Mogil JS, Schmidt BL, Maixner W, Dokholyan NV, Diatchenko L (2015) Structural and functional interactions between six-transmembrane $\mu$-opioid receptors and $\beta 2$-adrenoreceptors modulate opioid signaling. Sci Rep 5: 18198

Samuels EA, Clark SA, Wunsch C, Keeler LAJ, Reddy N, Vanjani R, Wightman RS (2020) Innovation during COVID-19: improving addiction treatment access. J Addict Med 14:e8-e9. https://doi.org/10. 1097/ADM.0000000000000685

Sanchez ES, Bigbee JW, Fobbs W, Robinson SE, Sato-Bigbee C (2008) Opioid addiction and pregnancy: perinatal exposure to buprenorphine affects myelination in the developing brain. Glia 56:1017-1027

Sarkisyan D, Hussain MZ, Watanabe H, Kononenko O, Bazov I, Zhou X, Yamskova O, Krishtal O, Karpyak VM, Yakovleva T, Bakalkin G (2015) Downregulation of the endogenous opioid peptides in the dorsal striatum of human alcoholics. Front Cell Neurosci 9:187
Sauriyal DS, Jaggi AS, Singh N (2011) Extending pharmacological spectrum of opioids beyond analgesia: multifunctional aspects in different pathophysiological states. Neuropeptides 45:175-188

Saylor D, Dickens AM, Sacktor N, Haughey N, Slusher B, Pletnikov M, Mankowski JL, Brown A, Volsky DJ, McArthur JC (2016) HIVassociated neurocognitive disorder-pathogenesis and prospects for treatment. Nat Rev Neurol 12:234-248

Schmaal L, van Velzen LS (2019) Deficits in white matter microstructure in Major depressive disorder: cause, consequence, or correlate? Biol Psychiatry 86:734-735

Scholl L, Seth P, Kariisa M, Wilson N, Baldwin G (2018) Drug and opioid-involved overdose deaths - United States, 2013-2017. MMWR Morb Mortal Wkly Rep 67:1419-1427

Schwartz L, Major EO (2006) Neural progenitors and HIV-1-associated central nervous system disease in adults and children. Curr HIV Res $4: 319-327$

Schwartz L, Civitello L, Dunn-Pirio A, Ryschkewitsch S, Berry E, Cavert W, Kinzel N, Lawrence DM, Hazra R, Major EO (2007) Evidence of human immunodeficiency virus type 1 infection of nestinpositive neural progenitors in archival pediatric brain tissue. $\mathrm{J}$ Neuro-Oncol 13:274-283

Secretary - United States Department of Health and Human Services (2017) Determination that a public health emergency exists. https://www.hhs.gov/sites/default/files/opioid\%20PHE\% 20Declaration-no-sig.pdf

Serafini RA, Pryce KD, Zachariou V (2020) The mesolimbic dopamine system in chronic pain and associated affective comorbidities. Biol Psychiatry 87:64-73

Sharma HS, Ali SF (2006) Alterations in blood-brain barrier function by morphine and methamphetamine. Ann N Y Acad Sci 1074:198-224

Sharma SK, Klee WA, Nirenberg M (1977) Opiate-dependent modulation of adenylate cyclase. Proc Natl Acad Sci U S A 74:3365-3369

Sheng WS, Hu S, Gekker G, Zhu S, Peterson PK, Chao CC (1997) Immunomodulatory role of opioids in the central nervous system. Arch Immunol Ther Exp 45:359-366

Sheng WS, Hu S, Lokensgard JR, Peterson PK (2003) U50,488 inhibits HIV-1 Tat-induced monocyte chemoattractant protein-1 (CCL2) production by human astrocytes. Biochem Pharmacol 65:9-14

Shinoda H, Marini AM, Cosi C, Schwartz JP (1989) Brain region and gene specificity of neuropeptide gene expression in cultured astrocytes. Science 245:415-417

Shrot S, Poretti A, Tucker EW, Soares BP, Huisman TA (2017) Acute brain injury following illicit drug abuse in adolescent and young adult patients: spectrum of neuroimaging findings. Neuroradiol $\mathrm{J}$ 30:144-150

Silberstein CH, O'Dowd MA, Chartock P, Schoenbaum EE, Friedland G, Hartel D, McKegney FP (1993) A prospective four-year follow-up of neuropsychological function in HIV seropositive and seronegative methadone-maintained patients. Gen Hosp Psychiatry 15:351-359

Singer BF (2019) Diverse characteristics of addiction necessitate multiple preclinical models. Biol Psychiatry 86:e43-e45

Singh KK, Spector SA (2009) Host genetic determinants of human immunodeficiency virus infection and disease progression in children. Pediatr Res 65:55R-63R

Sjogren P, Thomsen AB, Olsen AK (2000) Impaired neuropsychological performance in chronic nonmalignant pain patients receiving longterm oral opioid therapy. J Pain Symptom Manag 19:100-108

Smith JE, Co C, Freeman ME, Lane JD (1982) Brain neurotransmitter turnover correlated with morphine-seeking behavior of rats. Pharmacol Biochem Behav 16:509-519 
Smith JE, Co C, Lane JD (1984) Limbic acetylcholine turnover rates correlated with rat morphine-seeking behaviors. Pharmacol Biochem Behav 20:429-442

Smith MW, Dean M, Carrington M, Winkler C, Huttley GA, Lomb DA, Goedert JJ, O'Brien TR, Jacobson LP, Kaslow R, Buchbinder S, Vittinghoff E, Vlahov D, Hoots K, Hilgartner MW, O'Brien SJ (1997) Contrasting genetic influence of CCR2 and CCR5 variants on HIV-1 infection and disease progression. Hemophilia growth and development study (HGDS), multicenter AIDS cohort study (MACS), multicenter hemophilia cohort study (MHCS), San Francisco City Cohort (SFCC), ALIVE study. Science 277:959-965

Smith DB, Simmonds P, Bell JE (2014) Brain viral burden, neuroinflammation and neurodegeneration in HAART-treated HIV positive injecting drug users. J Neurovirol 20:28-38

Solbrig MV, Koob GF (2004) Epilepsy, CNS viral injury and dynorphin. Trends Pharmacol Sci 25:98-104

Song C, Rahim RT, Davey PC, Bednar F, Bardi G, Zhang L, Zhang N, Oppenheim JJ, Rogers TJ (2011) Protein kinase C $\zeta$ mediates $\mu$ opioid receptor-induced cross-desensitization of chemokine receptor CCR5. J Biol Chem 286:20354-20365

Sorrell ME, Hauser KF (2014) Ligand-gated purinergic receptors regulate HIV-1 tat and morphine related neurotoxicity in primary mouse striatal neuron-glia co-cultures. J NeuroImmune Pharmacol 9:233-244

Spruce BA, Curtis R, Wilkin GP, Glover DM (1990) A neuropeptide precursor in cerebellum: proenkephalin exists in subpopulations of both neurons and astrocytes. EMBO J 9(6):1787-1795

Squinto SP, Mondal D, Block AL, Prakash O (1990) Morphine-induced transactivation of HIV-1 LTR in human neuroblastoma cells. AIDS Res Hum Retrovir 6:1163-1168

Steele AD, Szabo I, Bednar F, Rogers TJ (2002) Interactions between opioid and chemokine receptors: heterologous desensitization. Cytokine Growth Factor Rev 13:209-222

Steele AD, Henderson EE, Rogers TJ (2003) Mu-opioid modulation of HIV-1 coreceptor expression and HIV-1 replication. Virology 309: 99-107

Stein C, Schafer M, Machelska H (2003) Attacking pain at its source: new perspectives on opioids. Nat Med 9:1003-1008

Stevens CW, Aravind S, Das S, Davis RL (2013) Pharmacological characterization of LPS and opioid interactions at the toll-like receptor 4 . Br J Pharmacol 168:1421-1429

Stiene-Martin A, Hauser KF (1991) Glial growth is regulated by agonists selective for multiple opioid receptor types in vitro. J Neurosci Res 29:538-548

Stiene-Martin A, Mattson MP, Hauser KF (1993) Opiates selectively increase intracellular calcium in developing type-1 astrocytes: role of calcium in morphine-induced morphologic differentiation. Brain Res Dev Brain Res 76:189-196

Stiene-Martin A, Zhou R, Hauser KF (1998) Regional, developmental, and cell cycle-dependent differences in $\mu, \delta$, and $\kappa$-opioid receptor expression among cultured mouse astrocytes. Glia 22:249-259

Stiene-Martin A, Knapp PE, Martin K, Gurwell JA, Ryan S, Thornton SR, Smith FL, Hauser KF (2001) Opioid system diversity in developing neurons, astroglia, and oligodendroglia in the subventricular zone and striatum: impact on gliogenesis in vivo. Glia 36:78-88

Strathdee SA, Beyrer C (2015) Threading the needle-how to stop the HIV outbreak in rural Indiana. N Engl J Med 373:397-399

Strazza M, Banerjee A, Alexaki A, Passic SR, Meucci O, Pirrone V, Wigdahl B, Nonnemacher MR (2014) Effect of mu-opioid agonist DAMGO on surface CXCR4 and HIV-1 replication in TF-1 human bone marrow progenitor cells. BMC research notes 7:752

Strazza M, Pirrone V, Wigdahl B, Dampier W, Lin W, Feng R, Maubert ME, Weksler B, Romero IA, Couraud PO, Nonnemacher MR
(2016) Prolonged morphine exposure induces increased firm adhesion in an in vitro model of the blood-brain barrier. International journal of molecular sciences 17:916

Stubbe-Drger B, Deppe M, Mohammadi S, Keller SS, Kugel H, Gregor N, Evers S, Young P, Ringelstein EB, Arendt G, Knecht S, Husstedt IW, German Competence Network HA (2012) Early microstructural white matter changes in patients with HIV: a diffusion tensor imaging study. BMC Neurol 12:23

Sturdevant CB, Joseph SB, Schnell G, Price RW, Swanstrom R, Spudich S (2015) Compartmentalized replication of R5 T cell-tropic HIV-1 in the central nervous system early in the course of infection. PLoS Pathog 11:e1004720

Sundar KS, Kamaraju LS, Dingfelder J, McMahon J, Gollapudi S, Wilson WH, Kong LY, Hong JS, Weiss JM, Lee JE (1995) $\beta$ Endorphin enhances the replication of neurotropic human immunodeficiency virus in fetal perivascular microglia. J Neuroimmunol 61: 97-104

Suomivuori CM, Latorraca NR, Wingler LM, Eismann S, King MC, Kleinhenz ALW, Skiba MA, Staus DP, Kruse AC, Lefkowitz RJ, Dror RO (2020) Molecular mechanism of biased signaling in a prototypical G protein-coupled receptor. Science 367:881-887

Suzuki S, Chuang LF, Yau P, Doi RH, Chuang RY (2002) Interactions of opioid and chemokine receptors: oligomerization of mu, kappa, and delta with CCR5 on immune cells. Exp Cell Res 280:192-200

Suzuki M, El-Hage N, Zou S, Hahn YK, Sorrell ME, Sturgill JL, Conrad DH, Knapp PE, Hauser KF (2011) Fractalkine/CX3CL1 protects striatal neurons from synergistic morphine and HIV-1 Tat-induced dendritic losses and death. Mol Neurodegener 6:78

Swan N (1997) CDC report highlights link between drug abuse and spread of HIV. In: NIDA notes (AIDS research), 2 edition: NIDA https://archives.drugabuse.gov/news-events/nida-notes/1997/04/ cdc-report-highlights-link-between-drug-abuse-spread-hiv

Szabo I, Wetzel MA, Zhang N, Steele AD, Kaminsky DE, Chen C, LiuChen LY, Bednar F, Henderson EE, Howard OM, Oppenheim JJ, Rogers TJ (2003) Selective inactivation of CCR5 and decreased infectivity of R5 HIV-1 strains mediated by opioid-induced heterologous desensitization. J Leukoc Biol 74:1074-1082

Szeto CY, Tang NL, Lee DT, Stadlin A (2001) Association between mu opioid receptor gene polymorphisms and Chinese heroin addicts. Neuroreport 12:1103-1106

Takahashi K, Yi H, Liu CH, Liu S, Kashiwagi Y, Patin DJ, Hao S (2018) Spinal bromodomain-containing protein 4 contributes to neuropathic pain induced by HIV glycoprotein 120 with morphine in rats. Neuroreport 29:441-446

Taylor S, Davies S (2010) Antiretroviral drug concentrations in the male and female genital tract: implications for the sexual transmission of HIV. Curr Opin HIV AIDS 5:335-343

Taylor BS, Sobieszczyk ME, McCutchan FE, Hammer SM (2008) The challenge of HIV-1 subtype diversity. N Engl J Med 358:1590 1602

Terashvili M, Wu HE, Schwasinger ET, Hung KC, Hong JS, Tseng LF (2008) (+)-morphine attenuates the (-)-morphine-produced conditioned place preference and the mu-opioid receptor-mediated dopamine increase in the posterior nucleus accumbens of the rat. Eur $\mathrm{J}$ Pharmacol 587:147-154

Theberge FR, Li X, Kambhampati S, Pickens CL, St Laurent R, Bossert JM, Baumann MH, Hutchinson MR, Rice KC, Watkins LR, Shaham Y (2013) Effect of chronic delivery of the Toll-like receptor 4 antagonist (+)-naltrexone on incubation of heroin craving. Biol Psychiatry 73:729-737

Thompson AR (2000) Opioids and their proper use as analgesics in the management of head and neck cancer patients. Am J Otolaryngol 21:244-254 
Thompson GL, Kelly E, Christopoulos A, Canals M (2015) Novel GPCR paradigms at the mu-opioid receptor. Br J Pharmacol 172:287-296

Tomlinson GS, Simmonds P, Busuttil A, Chiswick A, Bell JE (1999) Upregulation of microglia in drug users with and without presymptomatic HIV infection. Neuropathol Appl Neurobiol 25: 369-379

Tornatore C, Meyers K, Atwood W, Conant K, Major E (1994) Temporal patterns of human immunodeficiency virus type 1 transcripts in human fetal astrocytes. J Virol 68:93-102

Torres-Munoz J, Stockton P, Tacoronte N, Roberts B, Maronpot RR, Petito CK (2001) Detection of HIV-1 gene sequences in hippocampal neurons isolated from postmortem AIDS brains by laser capture microdissection. J Neuropathol Exp Neurol 60:885-892

Tran PB, Miller RJ (2005) HIV-1, chemokines and neurogenesis. Neurotox Res 8:149-158

Trescot AM, Datta S, Lee M, Hansen H (2008) Opioid pharmacology. Pain Physician 11:S133-S153

Tryoen-Toth P, Gaveriaux-Ruff C, Labourdette G (2000) Downregulation of mu-opioid receptor expression in rat oligodendrocytes during their development in vitro. J Neurosci Res 60:10-20

Turchan-Cholewo J, Liu Y, Gartner S, Reid R, Jie C, Peng X, Chen KC, Chauhan A, Haughey N, Cutler R, Mattson MP, Pardo C, Conant K, Sacktor N, McArthur JC, Hauser KF, Gairola C, Nath A (2006) Increased vulnerability of ApoE4 neurons to HIV proteins and opiates: protection by diosgenin and L-deprenyl. Neurobiol Dis 23: 109-119

Turchan-Cholewo J, Dimayuga FO, Ding Q, Keller JN, Hauser KF, Knapp PE, Bruce-Keller AJ (2008) Cell-specific actions of HIVTat and morphine on opioid receptor expression in glia. J Neurosci Res 86:2100-2110

Turchan-Cholewo J, Dimayuga FO, Gupta S, Keller JN, Knapp PE, Hauser KF, Bruce-Keller AJ (2009) Morphine and HIV-Tat increase microglial-free radical production and oxidative stress: possible role in cytokine regulation. J Neurochem 108:202-215

Tyor W, Fritz-French C, Nath A (2013) Effect of HIV clade differences on the onset and severity of HIV-associated neurocognitive disorders. J Neurovirol 19:515-522

UNODC (2019a) Executive summary: Conclusions and policy implications. United Nations Office on Drugs and Crime (UNODC). https:// wdr.unodc.org/wdr2019/prelaunch/WDR19_Booklet_1_ EXECUTIVE SUMMARY.pdf

UNODC (2019b). Depressants. United Nations Office on Drugs and Crime (UNODC). https://wdr.unodc.org/wdr2019/prelaunch/ WDR19_Booklet_3_DEPRESSANTS.pdf

UNODC (2019c). Global overview of drug demand and supply. United Nations Office on Drugs and Crime (UNODC). https://wdr.unodc. org/wdr2019/prelaunch/WDR19_Booklet_2_DRUG_DEMAND. pdf

Upadhyay J, Maleki N, Potter J, Elman I, Rudrauf D, Knudsen J, Wallin D, Pendse G, McDonald L, Griffin M, Anderson J, Nutile L, Renshaw P, Weiss R, Becerra L, Borsook D (2010) Alterations in brain structure and functional connectivity in prescription opioiddependent patients. Brain 133:2098-2114

Vaidya NK, Ribeiro RM, Perelson AS, Kumar A (2016) Modeling the effects of morphine on simian immunodeficiency virus dynamics. PLoS Comput Biol 12:e1005127

van Rij RP, Portegies P, Hallaby T, Lange JM, Visser J, de Roda Husman AM, van 't Wout AB, Schuitemaker H (1999) Reduced prevalence of the CCR5 $\Delta 32$ heterozygous genotype in human immunodeficiency virus-infected individuals with AIDS dementia complex. J Infect Dis 180:854-857
Veenhuis RT, Clements JE, Gama L (2019) HIV eradication strategies: implications for the central nervous system. Curr HIV/AIDS Rep 16:96-104

Venkatesan A, Nath A, Ming GL, Song H (2007) Adult hippocampal neurogenesis: regulation by HIV and drugs of abuse. Cellular and molecular life sciences 64:2120-2132

Venuto CS, Mollan K, Ma Q, Daar ES, Sax PE, Fischl M, Collier AC, Smith KY, Tierney C, Morse GD (2014) Sex differences in atazanavir pharmacokinetics and associations with time to clinical events: AIDS Clinical Trials Group study A5202. J Antimicrob Chemother 69:3300-3310

Vestal-Laborde AA, Eschenroeder AC, Bigbee JW, Robinson SE, SatoBigbee C (2014) The opioid system and brain development: effects of methadone on the oligodendrocyte lineage and the early stages of myelination. Dev Neurosci 36:409-421

Vilijn MH, Vaysse PJ, Zukin RS, Kessler JA (1988) Expression of preproenkephalin mRNA by cultured astrocytes and neurons. Proc Natl Acad Sci U S A 85:6551-6555

Violin JD, Crombie AL, Soergel DG, Lark MW (2014) Biased ligands at G-protein-coupled receptors: promise and progress. Trends Pharmacol Sci 35:308-316

Volkow ND, Morales M (2015) The brain on drugs: from reward to addiction. Cell 162:712-725

Volkow ND, Frieden TR, Hyde PS, Cha SS (2014) Medication-assisted therapies-tackling the opioid-overdose epidemic. N Engl J Med 370:2063-2066

Vuong C, Van Uum SH, O'Dell LE, Lutfy K, Friedman TC (2010) The effects of opioids and opioid analogs on animal and human endocrine systems. Endocr Rev 31:98-132

Wakeman SE, Green TC, Rich J (2020) An overdose surge will compound the COVID-19 pandemic if urgent action is not taken. Nat Med 26(6):819-820

Wallace DR, Dodson SL, Nath A, Booze RM (2006) Delta opioid agonists attenuate TAT(1-72)-induced oxidative stress in SK-N-SH cells. Neurotoxicology 27:101-107

Walsh SL, Preston KL, Stitzer ML, Cone EJ, Bigelow GE (1994) Clinical pharmacology of buprenorphine: ceiling effects at high doses. Clin Pharmacol Ther 55:569-580

Wang GJ, Chang L, Volkow ND, Telang F, Logan J, Ernst T, Fowler JS (2004) Decreased brain dopaminergic transporters in HIVassociated dementia patients. Brain 127:2452-2458

Wang X, Loram LC, Ramos K, de Jesus AJ, Thomas J, Cheng K, Reddy A, Somogyi AA, Hutchinson MR, Watkins LR, Yin H (2012) Morphine activates neuroinflammation in a manner parallel to endotoxin. Proc Natl Acad Sci U S A 109:6325-6330

Wen H, Lu Y, Yao H, Buch S (2011) Morphine induces expression of platelet-derived growth factor in human brain microvascular endothelial cells: implication for vascular permeability. PLoS One 6: e21707

Whelan PJ, Remski K (2012) Buprenorphine vs methadone treatment: a review of evidence in both developed and developing worlds. J Neurosci Rural Pract 3:45-50

Williams DW, Calderon TM, Lopez L, Carvallo-Torres L, Gaskill PJ, Eugenin EA, Morgello S, Berman JW (2013a) Mechanisms of HIV entry into the CNS: increased sensitivity of HIV infected CD14+CD16+ monocytes to CCL2 and key roles of CCR2, JAMA, and ALCAM in diapedesis. PLoS One 8:e69270

Williams JT, Ingram SL, Henderson G, Chavkin C, von Zastrow M, Schulz S, Koch T, Evans CJ, Christie MJ (2013b) Regulation of $\mu$-opioid receptors: desensitization, phosphorylation, internalization, and tolerance. Pharmacol Rev 65:223-254

Williams DW, Veenstra M, Gaskill PJ, Morgello S, Calderon TM, Berman JW (2014) Monocytes mediate HIV neuropathogenesis: 
mechanisms that contribute to HIV associated neurocognitive disorders. Curr HIV Res 12:85-96

Winkler C et al (1998) Genetic restriction of AIDS pathogenesis by an SDF-1 chemokine gene variant. ALIVE study, hemophilia growth and development study (HGDS), multicenter AIDS cohort study (MACS), multicenter hemophilia cohort study (MHCS), San Francisco City Cohort (SFCC). Science 279:389-393

Wohlschlaeger J, Wenger E, Mehraein P, Weis S (2009) White matter changes in HIV-1 infected brains: a combined gross anatomical and ultrastructural morphometric investigation of the corpus callosum. Clin Neurol Neurosurg 111:422-429

Wollman SC, Hauson AO, Hall MG, Connors EJ, Allen KE, Stern MJ, Stephan RA, Kimmel CL, Sarkissians S, Barlet BD, Flora-Tostado C (2019) Neuropsychological functioning in opioid use disorder: a research synthesis and meta-analysis. Am J Drug Alcohol Abuse 45: $11-25$

Wu DT, Woodman SE, Weiss JM, McManus CM, D'Aversa TG, Hesselgesser J, Major EO, Nath A, Berman JW (2000) Mechanisms of leukocyte trafficking into the CNS. J Neurovirol 6(Suppl 1):S82-S85

Wu Y, Storey P, Cohen BA, Epstein LG, Edelman RR, Ragin AB (2006) Diffusion alterations in corpus callosum of patients with HIV. AJNR Am J Neuroradiol 27:656-660

Wu HY, Tang XQ, Mao XF, Wang YX (2017) Autocrine Interleukin-10 mediates glucagon-like Peptide-1 receptor-induced spinal microglial $\beta$-endorphin expression. J Neurosci 37:11701-11714

Wybran J, Appelboom T, Famaey JP, Govaerts A (1979) Suggestive evidence for receptors for morphine and methionine-enkephalin on normal human blood T lymphocytes. J Immunol 123:1068-1070

Xu C, Fitting S (2016) Inhibition of GABAergic neurotransmission by HIV-1 Tat and opioid treatment in the striatum involves $\mu$-opioid receptors. Front Neurosci 10:497

Xu R, Feng X, Xie X, Zhang J, Wu D, Xu L (2012) HIV-1 tat protein increases the permeability of brain endothelial cells by both inhibiting occludin expression and cleaving occludin via matrix metalloproteinase-9. Brain Res 1436:13-19

Xu J, Xu M, Bolan E, Gilbert AK, Pasternak GW, Pan YX (2014a) Isolating and characterizing three alternatively spliced mu opioid receptor variants: $\mathrm{mMOR}-1 \mathrm{~A}, \mathrm{mMOR}-1 \mathrm{O}$, and $\mathrm{mMOR}-1 \mathrm{P}$. Synapse 68:144-152

Xu J, Lu Z, Xu M, Pan L, Deng Y, Xie X, Liu H, Ding S, Hurd YL, Pasternak GW, Klein RJ, Cartegni L, Zhou W, Pan YX (2014b) A heroin addiction severity-associated intronic single nucleotide polymorphism modulates alternative pre-mRNA splicing of the mu opioid receptor gene OPRM1 via hnRNPH interactions. J Neurosci 34: 11048-11066
Xu AH, Yang Y, Sun YX, Zhang CD (2018) Exogenous brain-derived neurotrophic factor attenuates cognitive impairment induced by okadaic acid in a rat model of Alzheimer's disease. Neural Regen Res 13:2173-2181

Xuan A, Wang GB, Shi DP, Xu JL, Li YL (2013) Initial study of magnetic resonance diffusion tensor imaging in brain white matter of early AIDS patients. Chin Med J 126:2720-2724

Yousif S, Saubamea B, Cisternino S, Marie-Claire C, Dauchy S, Scherrmann JM, Decleves X (2008) Effect of chronic exposure to morphine on the rat blood-brain barrier: focus on the P-glycoprotein. J Neurochem 107:647-657

Yousif S, Chaves C, Potin S, Margaill I, Scherrmann JM, Decleves X (2012) Induction of P-glycoprotein and Bcrp at the rat blood-brain barrier following a subchronic morphine treatment is mediated through NMDA/COX-2 activation. J Neurochem 123:491-503

Yuan Y, Arnatt CK, El-Hage N, Dever SM, Jacob JC, Selley DE, Hauser KF, Zhang Y (2013) A bivalent ligand targeting the putative $\mu$ opioid receptor and chemokine receptor CCR5 heterodimers: binding affinity versus functional activities. MedChemComm 4:847-851

Yuferov V, Butelman ER, Ho A, Morgello S, Kreek MJ (2014) Neurocognitive and neuroinflammatory correlates of PDYN and OPRK1 mRNA expression in the anterior cingulate in postmortem brain of HIV-infected subjects. J Neuroinflammation 11:5

Zhu C, Han Q, Samoshkin A, Convertino M, Linton A, Faison EM, Ji RR, Diatchenko L, Dokholyan NV (2019) Stabilization of $\mu$-opioid receptor facilitates its cellular translocation and signaling. Proteins 87:878-884

Zou S, Fitting S, Hahn YK, Welch SP, El-Hage N, Hauser KF, Knapp PE (2011) Morphine potentiates neurodegenerative effects of HIV-1 Tat through actions at $\mu$-opioid receptor-expressing glia. Brain 134:3613-3628

Zou S, Fuss B, Fitting S, Hahn YK, Hauser KF, Knapp PE (2015) Oligodendrocytes are targets of HIV-1 Tat: NMDA and AMPA receptor-mediated effects on survival and development. J Neurosci 35:11384-11398

Zou S, Balinang JM, Paris JJ, Hauser KF, Fuss B, Knapp PE (2019) Effects of HIV-1 Tat on oligodendrocyte viability are mediated by CaMKII $\beta-G S K 3 \beta$ interactions. J Neurochem 149:98-110

Zubieta JK, Smith YR, Bueller JA, Xu Y, Kilbourn MR, Jewett DM, Meyer CR, Koeppe RA, Stohler CS (2002) Mu-opioid receptormediated antinociceptive responses differ in men and women. J Neurosci 22:5100-5107

Publisher's Note Springer Nature remains neutral with regard to jurisdictional claims in published maps and institutional affiliations. 